\title{
DOCTORS AND HOSPITALS: AN ANTITRUST PERSPECTIVE ON TRADITIONAL RELATIONSHIPS
}

\author{
Clark C. Havighurst*
}

Under new pressures for cost containment, hospitals are increasingly asserting interests that conflict with those of physicians. Professor Havighurst argues that legal rules under which practitioners have challenged denials of hospital admitting privileges should be clarified in order that hospitals can more effectively carry out their new costcontainment and other responsibilities. He invokes antitrust law's "essential-facilities" doctrine to protect those abused by their competitors on a hospital staff, but he contends that, if a hospital participates in decisionmaking as an independent actor-even though it acts in concert with its physicians-, antitrust courts should lower the level of scrutiny to a point at which most challenges can be dismissed summarily. He analogizes restraints imposed by hospitals on competition between health professionals to vertical restraints of other kinds, and draws conclusions critical of doctrine traditionally applicable to the latter.

\section{TABLE OF CONTENTS}

INTRODUCTION ............................ 1072

I. INFLuenCes Shaping the Hospital ENTERPRise ...... 1077

A. The Expanding Decisionmaking Role of Hospitals ... 1077

B. Appraising the Balance of Power ................. 1082

C. The Internal Organization of Hospitals ............. 1084

II. The Hospital Medical Staff in ANtitrust

Perspective ................................ 1092

III. Statutory and COMmon LaW Governing Hospital AdMitTing Privileges-The NeEd for a NeW

Rationale................................. 1098

* Professor of Law and Director of the Program on Legal Issues in Health Care, Duke University. An earlier, less technical version of this article was presented at the Ninth Annual Private Sector Conference, Duke University Medical Center, March 12, 1984, and is to be published with the conference proceedings in Physicians and Hospitals: The Great ParTnership at A CROSSRoads (D. Yaggy \& P. Hodgson eds. 1985). This version is published with the permission of the organizers of that conference. Support for the research was provided under Grant No. HS 04089 from the National Center for Health Services Research, United States Department of Health and Human Services. 
IV. A Refutation of Two COMmon ANTITRUST

Fallacies Concerning Hospital Privileges........ 1101

A. The Fallacy That the Administration of Privileges

Constitutes "Professional Self-Regulation"........... 1101

B. The Fallacy That a Denial of Privileges Constitutes a

"Group Boycott" or "Concerted Refusal to Deal" .... 1104

V. ANTITRUST Principles APPlicable to Admitting

Privileges Decisions.......................... 1108

A. The "Essential-Facilities" Doctrine ............... 1111

1. Uniqueness of the Hospital .................... 1114

2. Competitor (i.e., Medical-Staff) Control .......... 1116

3. The Tests Employed in Reviewing Medical-Staff

Decisions ................................. 1122

B. Judicial Review of Hospital Actions ............... 1125

1. The Hospital as a Joint Venture ............... 1126

2. Legal Standards for Reviewing Hospital Actions ... 1131

a. Procedural requirements ................. 1132

b. A rational-basis test for substantive actions .... 1133

C. Policy Considerations ........................ 1136

VI. ANTITrust RULES IN ACTION-A Hypothetical CASE 1139

VII. IMPLICATIONS FOR THE JURISDICTIONAL REQUIREMENT OF AN EFFECT ON INTERSTATE COMMERCE ........... 1142

VIII. ANALOGIES TO THE LAW Governing Other Vertical RESTRAINTS .................................... 1144

A. Manufacturer/Distributor Agreements............ 1145

B. Hospitals' Exclusive Contracts for Physician Services .. 1148

C. Health Care Practitioners Versus Other Middlemen ... 1151

IX. CONClusion: A Strengthened Role for Hospitals 1157

\section{INTRODUCTION}

The new competitive climate of the health care industry ${ }^{1}$ is changing relationships between hospitals and physicians. The scramble for new business is bringing some hospitals and physicians into direct competi-

1. The health care industry appears to be in the process of changing its essential character, from a stable and largely self-regulating system financed by passive third-party payers to an unruly competitive industry facing increasingly cost-conscious customers. See, e.g., SYNTHESIS OF PR1VAte SeCtor Health CaRe Initiativis (1984) (report prepared for the Office of the Assistant Secretary for Planning and Evaluation, Department of Health and Human Services); P. STARR, THE Social Transformation of AMERICAN MEdicine 439.49 (1982); J. GoldSMith, CAN Hospitals Survive?: THE NEW Competitive Health CARE MARKet 13-14 (1981). The foundations for these dramatic changes were laid by new policy thinking, antitrust enforcement, and government's withdrawal from the effort to control private health care costs by regulatory means. Sec infra text accompanying notes 87-88. See generally A. ENThoven, Health Plan: The ONLy PRACTICal Solution to the Soaring Cost of Medical Care, $x x i-x x y$ (1980); C. Havighurst, Deregulating the Health Care Industry $443-50$ (1982); Market Reforms in Health Care 
tion with each other in the provision of certain ambulatory care. ${ }^{2}$ Competitive pressures are also causing an increase in the formal integration of hospital and physician services in health maintenance organizations $(\mathrm{HMOs})^{3}$ and in new kinds of joint venture. ${ }^{4}$ In perhaps the most important development, increasing cost-consciousness on the part of public and private purchasers of hospital services is forcing hospitals to become more cost-conscious themselves, causing them in turn to assert interests at variance with those of the physicians with whom they cooperate in providing a vast quantity of inpatient and other services. Thus, competi-

(J. Meyer ed. 1983); A NEW APPROACh to the Economics of Health Care (M. Olson ed. 1981); P. STARR, supra at 379-419; Market-Oriented Approaches to Achieving Health Policy Goals, 34 VAND. L. REV. 849 (1981); The Spiraling Costs of Health Care-Rx: Competition, Bus. WK., Feb. 8,1982 , at 58 .

2. Partly to increase the flow of inpatients, hospitals are integrating vertically into the provision of outpatient services by opening clinics staffed by salaried doctors, thus directly competing for patients with their staff physicians. At the same time, many physicians are offering new services of a kind that have traditionally been provided by hospitals. Thus, physicians have purchased expensive diagnostic equipment for their offices, have sponsored the development of ambulatory surgical facilities, and have opened clinics for the treatment of minor emergencies. See, e.g., J. GoLDSMITH, supra note 1, at 25-48, 136-44, 175-77; Goldsmith, MDs and Hospitals: Conflict or Partnership?, HosP. MED. STAFF, May, 1983, at 3; Moxley \& Roeder, New Opportunities for Out-Of-Hospital Health Services, 310 NEW ENG. J. MED. 193, 19495 (1984).

3. HMO arrangements with physicians vary widely. There are, however, three basic types of HMO: a "staff" model, a "group" model, and an "individual practice association" model. In the socalled staff model, the HMO employs physicians on a salaried basis; occasionally such physician/ employees have organized a labor union for purposes of collective bargaining. In the group model, the HMO entity contracts for physician services with an independent physician-sponsored entity. In the individual practice association model, the HMO contracts with independent practitioners individually or in small groups. HMO arrangements with hospitals range from directly owning the hospital, to contracting with independent hospitals, to using hospitals selected by contracting physicians. See generally American Medical Association, Health Maintenance OrganizaTIONS (1980). Thus, integration of hospital and physician services in an HMO is always a matter of degree.

4. More recent innovations integrating hospitals and physicians include both insurer-sponsored and provider-sponsored "preferred provider organizations" (PPOs). These arrangements may or may not incorporate both physicians and hospitals and may involve much less actual integration than is found in HMOs. See generally Attorneys and Physicians Examine Preferred ProVIDER ORGANIZATIONS (J. Waxman ed. 1984); Special Report, Health Care Industry, Business Show Increasing Interest in PPO Concept, FED'N OF AM. HOSPS. REV., July-Aug. 1982, at 12-13. In yet another recent development, many hospitals are currently exploring the possibility of entering into joint ventures with their physicians; most of the arrangements being considered would involve the creation of a single corporate entity under the joint control of a hospital and a physician group. See, e.g., Swett \& Conley, Joint Ventures: The Theory and Practice, HosPS., May 1, 1984, at 95; Yanish, Hospitals Work with M.D.s to Smooth MeSH Partnerships' Rough Edges, MoD. HealTHCARE, Feb. 15, 1984, at 58; Hospital Joins Doctors to Form Corporation, Hosps., Apr. 16, 1984, at 39. For possible legal limits on such organizational innovations, see infra note 53. Under the antitrust laws, the creation of such joint ventures must be scrutinized with care to determine whether important competition, see supra note 2 , is being sacrificed. 
tion in health care, which until recently was construed by most observers to mean only the gradual spread of HMOs, ${ }^{5}$ is now making itself felt even within the traditional hospital, the main focal point of fee-for-service medical practice. ${ }^{6}$

Hospitals, as they have evolved in the United States, ${ }^{7}$ render the vast majority of their services in conjunction with physicians who market their own services independently of the hospital. As traditionally operated, ${ }^{8}$ the hospital allows certain of these practitioners to admit their patients to its facility and to draw upon its resources and support services in order to provide treatment. The practitioners thus favored with admitting privileges are typically organized under the hospital's auspices into a self-governing medical staff, which is charged with performing numerous technical functions essential to the hospital's operation. Historically, this organizational model implied certain role definitions. Thus, the individual physician was generally perceived to be the final arbiter of treatment decisions and was accorded a very wide range of discretion; although formally accountable to the hospital, the physician was practically

5. The cultivation of "alternative delivery systems" in the 1970 's, by presuming the continued operation of a single dominant "system," implied a more limited role for competition than events are revealing. See generally Havighurst, Competition in Health Services: Overview, Issues and Answers, 34 VAND. L. Rev. 1117, 1125-27 (1981); Havighurst \& Hackbarth, Private Cost Containment, 300 NEw ENG. J. MED. 1298, 1298-1305 (1979); McClure, On Broadening the Definition of and Removing Regulatory Barriers to a Competitive Health Care System, 3 J. Health PoL., Pol'y \& LaW 303 (1978).

6. See generally J. GoldSMITH, supra note 1; Armistead \& Hofmann, Involving the Physician in Cost Containment, HosP. FIN. MGMT., Jan. 1981, at 52; Goldsmith, supra note 2; Holoweiko, A Doomsday Timetable for Independent Practice, MED. Econ., June 27, 1983, at 31; Noie, Shortell, \& Morrisey, A Survey of Hospital Medical Staffs, (Pts. 1 \& 2), Hosps., Dec. 1, 1983, at 80, Dec. 16, 1983, at 91; Shortell, Physician Involvement in Hospital Decision Making, in THE NEW HEALTH CARE for Profit: Doctors and Hospitals in a CoMpetitive ENvironment 73 (B. Gray ed. 1983) [hereinafter cited as HeAlth CARE FOR Profrt]; Managing Tensions Between Hospitals and Physicians Called Major Challenge, HosPs., June 1, 1983, at 17.

7. See generally M. Roemer \& J. Friedman, Doctors in Hospitals: Medical Staff Organization and Hospital Performance $29-43$ (1971); P. STaRr, supra note 1, at 145-79; Hospital Organization and Management 1-108 (J. Rakich \& K. Darr eds. 3d ed., 1983).

8. On hospital organization generally, see M. ROEMER \& J. FRIEDMAN, supra note 7, at 8392; Georgopoulos \& Mann, The Hospital as an Organization, in HosPITAL ORganization AND Management (3d ed. 1983); Moore \& Wood, Power and the Hospital Executive, Hosp. \& HeAtTH SERvs. AD., Spring 1979, at 30; Prybil, The Evolution of Hospital Governance, in HeAlth ManAgEMENT FOR TOMORRow 76 (S. Levey \& T. McCarthy eds. 1980). Perhaps the most authoritative source of descriptive information on the organization of hospitals is the Joint Commission on Accreditation of Hospitals (JCAH), to whose standards most hospitals seek to conform. See, e.g., JoINT COMMISSION ON ACCREDITATION OF HOSPITALS, ACCREDITATION MANUAL FOR HospiTALS/1984 (rev. ed. 1983) [hereinafter cited as 1984 MANUAL]. See also infra notes $46-50$ and accompanying text. For legal perspectives on hospital organization, see, for example, W. ISELE, The Hospital Medical StafF: Its Legal Rights and Responsibilities 26-47 (1984); $R$. Miller, Problems in Hospital LaW 17-43, 115-43 (4th ed. 1983); A. Southwick, THe LaW of Hospital and Health Care Administration 31-57 (1978). 
accountable only to his (ignorant) patient and his (usually tolerant) professional peers. The hospital's accepted task was not to control the physician but to facilitate his mission by maintaining the necessary resources and mobilizing them in response to the physician's call. ${ }^{9}$

As a result of the broad consensus supporting the traditional organizational model of the hospital and the related delineation of roles, hospital/physician relations were relatively untroubled for a long time. ${ }^{10}$ The harmony and stability that prevailed probably could not have been maintained, however, if hospitals had not enjoyed a high degree of freedom from budgetary and other constraints imposed by market forces, by government, or by any other party whose interests conflicted significantly with physician preferences. ${ }^{11}$ Because the third-party financing system that developed to pay for most hospital care reimbursed hospitals' costs and seldom challenged the bills resulting from physician treatment decisions, hospitals did not find it necessary to step out of the passive role assigned to them. The new tensions arising in hospital/physician relationships today appear to be a direct result of a breakdown in the old "social contract" that left hospitals largely free, financially and otherwise, to do the doctors' bidding.

A hospital's ability to control its costs and to compete effectively in the emerging economic environment depends to a large degree upon its ability to influence the performance and practice styles of independent practitioners. Because a hospital can significantly influence physician behavior only by its perceived readiness to exercise its right to withhold or condition admitting privileges, ${ }^{12}$ an increase in the number of disputes

9. Management literature frequently refers to the hospital as the physician's "workshop." Another metaphor that forcefully conveys one view of the hospital is that of the aircraft carrier, which is portrayed by David Kinzer as obligated only to support and not to define its pilots' missions. Kinzer, The Only Team That Pilots-and Doctors-Recognize As Their Own, MoD. Hosp., May 1959, at 59; Kinzer, Physicians and Hospitals-Tensions in the Relationship, in PHYSICIANS AND Hospitals: The Great Partnership at a Crossroads (D. Yaggy \& P. Hodgson eds. 1985). Kinzer's observations were based on experiences in World War II, however. Changing technology has reduced the independence of today's fighter pilots - and today's physicians-and made possible a synergism that requires a higher degree of organizational integration and control.

10. The problems that arose were prompted mostly by changes in the tort liability of hospitals. See infra text accompanying notes 20-24. Although disputes were sometimes vigorous, they covered a very narrow range of issues compared to those that are arising today. See, e.g., COMMITTEE ON Private Practice, AMA Council on Medical Service, Report on Physician-Hospital RelATIONS 3 (approved by American Medical Association (AMA) House of Delegates June 1974; discussing the relative authority of the governing board and the self-governing medical staff) [hereinafter cited as PRIVATE PRACTICE REPORT]. For historical references, see supra note 7.

11. The nonprofit character of the great majority of major hospitals significantly reduced the likelihood of economic conflict between physicians and hospital proprietors. See infra notes 30-33 and accompanying text.

12. A hospital lacking freedom to hire and fire, to alter responsibilities, and to adjust compensation on a discretionary basis is reduced to using persuasion as a managerial device. The disposition 
over such privileges is likely to be a consequence of hospitals' assertion of their new competitive interests. Privileges disputes may also be manifestations of competition of another kind, however. As competition increases between physicians themselves and between physicians and other types of practitioners, the stakes both of those who possess and of those who seek admitting privileges also increase. As a result, medical staffs may attempt to deny privileges to unwanted competitors, and competitors excluded from a hospital may resort to the courts as a way of forcing entry. The recent apparent increase in litigation over denials or revocations of admitting privileges ${ }^{13}$ may therefore reflect either the emergence of healthy competitive forces in the health care industry, or anticompetitive abuses by physicians, or some combination of the two. Courts may be called upon to determine which of these alternative explanations best fits a particular dispute over admitting privileges.

This article, in examining the law governing the withholding of admitting privileges, focuses principally on antitrust issues. It does so partly because analysis in antitrust terms best fits the industry's new circumstances and can illuminate the interplay of law, health policy, and industry developments. In addition, an antitrust analysis of privileges disputes can also serve to highlight the current confusion in antitrust law as it relates to the activities of professionals, to so-called group boycotts, and to vertical restraints of trade. The analysis of the hospital/physician relationship offered herein is intended to eliminate some of the confusion surrounding each of these matters and to advance understanding not only of the operation of health care markets but also of the law's role in promoting effective competition and efficient performance in markets of all kinds. There are important lessons for antitrust law in general in this investigation of specific legal problems arising in the administration of the complex modern hospital.

of staff privileges provides the hospital with virtually its only opportunity to exercise direct control over independent practitioners. See infra note 219.

13. See generally W. ISELE, supra note 8, at 67-90; Hein, Hospital Staff Privileges and the Courts: Practice and Prognosis, 34 Fed'N INs. Couns. Q., 157, 158-65 (1984); McCall, The Hospital's Liability for Denying, Suspending, and Granting Staff Privileges, 32 BAYLOR L. REv. 175, 175 (1980); Tabor, The Battle for Hospital Privileges, 249 J. A.M.A. 526 (1983); Barred Doctors Go Before the Bar, Med. World News, Jan. 18, 1982, at 72. These references highlight potential common law and statutory, as well as antitrust, causes of action. On common law actions, see infra text accompanying notes 82-94. A list of antitrust cases filed in recent years by disappointed applicants against hospitals and medical staffs appears in Kissam, Webber, Bigus \& Holzgraefe, Antitrust and Hospital Privileges: Testing the Convention Wisdom, 70 CaLIF. L. Rev. 595, 596 n.2 (1982) [hereinafter cited as Kissam \& Webber]. For later cases, see infra note 118. A study by the National Health Lawyers Association revealed that nearly half of the pending antitrust cases in the health care industry involve disputes over access to medical staff privileges. 46 ANTITRUST \& TRADE REG. REP. (BNA) No. 1150, at 187 (1984). See also infra notes 18-19 and accompanying text. 


\section{INFLuences Shaping the Hospital ENTERPRISE}

Various influences have shaped and are shaping hospitals and their relationships with physicians. A discussion of these influences, in addition to showing how hospital organizational and operational patterns reached the point from which new departures are now proceeding, will also suggest some of the opportunities that exist for restructuring these relationships. It will also call attention to the need for a legal environment that does not foreclose or inhibit responsible adaptations that hospitals might make to cope with their new economic circumstances.

\section{A. The Expanding Decisionmaking Role of Hospitals.}

The pressures and incentives that are currently changing the environment of hospital decisionmaking are not hard to identify. First, hospitals have new financial problems due to changes in the ways in which they are paid. The most important development is the phase-out of retrospective cost reimbursement under the Medicare program and its replacement by a policy of paying fixed "DRG" allowances-that is, prospectively determined prices based on the patient's diagnosis. ${ }^{14}$ In

14. "DRG" stands for "diagnosis-related group." Under the new payment system, which is being phased in over a four-year period beginning in 1984, a hospital is paid a fixed amount based primarily on which of 468 DRGs the patient falls into; adjustments are made for the different costs of urban and rural hospitals, and some provision is made for "outliers"-cases involving especially high costs. See 42 U.S.C.A. $\$ 1395$ ww (West 1983). The provisions of the Social Security Act that deal with prospective payment were added by the Social Security Amendments of 1983, Pub. L. No. $98-21, \S 601,97$ Stat. 65, 149-63 (amending Title XVIII, $\S 1886$ of the Social Security Act, which was added by the Tax Equity and Fiscal Responsibility Act of 1982, Pub. L. No. 97-248, § 101(a)(1), 96 Stat. 331, 331-36). The latest regulations appear in 49 Fed. Reg. 234, 243-77 (1984) (with the regulations most relevant to prospective payment to be codified at 42 C.F.R. $\$ \$ 405.470-.477)$. The regulations are summarized in 1 MEDICARE \& MEDICAID GuIDE (CCH) ๆI 4200-4267 (1984).

The theoretical rationale for shifting to prospectively determined rates is the presumed desirability of the cost-containment incentives resulting from payment practices that penalize high-cost care and allow hospitals to retain as profit any savings they achieve that enable them to treat the patient for less than the fixed rate. With the possible exception of the extension of the antitrust laws to the health care sector, see infra notes $87-88$ and accompanying text, the new payment policy is the most important change in federal health policy since the adoption of the Medicare and Medicaid programs. See generally A. SoRK1N, HeALTH ECONOMICS: AN INTRODUCT1ON 94-101 (rev. 2d ed. 1984); Iglehart, Medicare Begins Prospective Payment of Hospitals, 308 New ENG. J. MED. 1428 (1983); Special Report, Prospective Payment: A New Direction for Hospitals, FED'N OF AM. HoSPS. REV., Mar.-Apr. 1983, at 24-64. Consideration is currently being given to including physician services within the DRG allowance, a move that would have even more profound effects on hospital/ physician relationships. See infra note 285 . Whether prospective payment is a complete or final answer to Medicare's problems is doubtful, however. Not only is its arbitrariness a cause for conceru, especially as technology changes, but it is subject to some manipulation and evasion. See, e.g., Simborg, DRG Creep: A New Hospital-Acquired Disease, 304 NEW ENG. J. MED. 1602, 1604 (1981); Wennberg, McPherson \& Caper, Will Payment Based on Diagnosis-Related Groups Control Hospital Costs?, 311 NEw ENG. J. MED. 295, 299 (1984). The next generation of cost containment in public programs could go in either of two directions-toward a "voucher" system, in which government 
addition, however, other payers, both public and private, are beginning to negotiate with hospitals and to steer their beneficiaries toward lowercost facilities; price competition among hospitals is thus gradually becoming a reality. ${ }^{15}$ The result of these measures is that hospitals are becoming more cost-conscious and are beginning to insist that physicians take account of economic realities in their use of the hospital. ${ }^{16}$ Organized medical staffs increasingly perceive their own stake in the financial health of their hospitals and are beginning to assist them in their efforts to make ends meet and to compete successfully.

A second factor affecting hospital/physician relationships is the recent growth in the supply of physicians. ${ }^{17}$ Hospitals have always needed doctors. For the first time, however, they are now able to acquire them in something other than a sellers' market, with the result that a doctor's willingness to cooperate in helping the hospital solve its cost problem is becoming a factor in the award of admitting privileges. Doctors are being asked to assist in cost containment both by participating in staff committee work and by modifying their styles of practice.

Another aspect of the increased physician supply is the increased threat of litigation when admitting privileges are denied. ${ }^{18}$ Not only are denials more frequent, but litigation is more likely because physicians who lose privileges are apt to find it harder to establish themselves elsewhere. Physicians denied privileges may also have more reason than previously to suspect anticompetitive motives on the part of their peers in excluding them. Finally, legal developments have expanded the availability of antitrust theories that hold out the possibility of treble damages if anticompetitive motives can be proved, thus making lawsuits more in-

pays a fixed amount to enable beneficiaries to join private health plans, or toward direct regulation of all hospital charges. On such regulation, see infra note 37.

15. See, e.g., Melia, Aucoin, Duhl \& Kurokawa, Competition in the Health Care Marketplace: A Beginning in California, 308 NEw ENG. J. MED. 788 (1983); Tatge, Hospitals Are Selling Their Ability to Cut Big Employers' Health Costs, MOD. HeALTHCARE, July 1984, at 46; Special Report, supra note 4.

16. See, e.g., Spivey, The Relation between Hospital Management and the Medical Staff under Prospective Payment, 310 NEw ENG. J. MED. 984, 985 (1984).

17. The Graduate Medical Education National Advisory Committee (GMENAC) documented the expanding supply of physicians-due largely to federal and state government subsidization of medical education-in a study designed to evaluate warnings in the 1970 s of an impending excess. United States Graduate Medical Education National advisory Committee, SumMARY REPORT TO THE SECRETARY, DEPARTMENT OF HEALTH AND HUMAN SERVICES (1980); see also Ginzberg, Brann, Hiestand \& Ostow, The Expanding Physician Supply and Health Policy: The Clouded Outlook, 59 MILBANK MEM. Fund. Q. 508 (1981); Tarlov, Shattuck Lecture-The Increasing Supply of Physicians, the Changing Structure of the Health-Services System, and the Future Practice of Medicine, 308 NEw ENG. J. MED. 1235 (1983).

18. See supra note 13. 
viting. ${ }^{19}$ Because litigation is costly even if the hospital ultimately prevails, a new seriousness surrounds decisions on staff privileges.

Although these recent changes in the environment have increased the interest that hospital boards and administrators take in patient care and in the other activities of doctors in the hospital, the trend in this direction is not entirely new. A number of earlier developments had very similar effects and produced conflicts similar to, although perhaps not as intense as, those being seen today. Notable among these earlier developments are the changes in tort doctrine in the 1950's and 1960's that significantly increased the exposure of hospitals to suits for personal injury. ${ }^{20}$ The first of these legal developments, the elimination of charitable immunity, was quickly followed by major expansions of vicarious liability. ${ }^{21}$ In particular, a famous 1965 case in Illinois, Darling $v$. Charleston Community Memorial Hospital, 22 imposed liability on a hospital for an injury caused by an attending physician assigned by it to duty in the emergency room. ${ }^{23}$ More surprising than the legal result in that case was the widespread reaction to it, which suggested that hospital managers had been waiting for some excuse to demand more cooperation and quality assurance from their medical staffs. ${ }^{24}$ Finally, since the Darling case, a number of decisions have held hospitals liable for not screening their professional staffs more carefully. ${ }^{25}$ Although the cumulative effect of these changes in tort law was a stengthening of the hospitals' stake in the quality of care provided, it is widely believed that many hospitals still do not take enough care to ensure that physicians using the

19. See generally Dolan \& Ralston, Hospital Admitting Privileges and the Sherman Act, 18 Hous. L. REv. 707, 712-13, 724-78 (1981); Drexel, The Antitrust Implications of the Denial of Hospital Staff Privileges, 36 U. Mrami L. Rev. 207 (1982); Kissam \& Webber, supra note 13.

20. See generally A. SouTHwick, supra note 8, at 346-423; Goldberg, The Duty of Hospitals and Hospital Medical Staffs to Regulate the Quality of Patient Care: A Legal Perspective, 14 PAC. L.J. 55 (1982) (potential hospital liability for negligent appointment of staff physicians).

21. Hospitals first became responsible for the negligence of their professional employees, see, e.g., Bing v. Thunig, 2 N.Y.2d 656, 665-67, 143 N.E.2d 3, 7-9, 163 N.Y.S.2d 3, 9-12 (1957); Bernardi v. Community Hosp. Ass'n, 166 Colo. 280, 291, 443 P.2d 708, 713 (1968); later, they became vicariously liable for the negligent acts of professionals who, although not technically employees, were seen by patients as agents of the hospital, see, e.g., Grewe v. Mount Clemens Gen. Hosp., 404 Mich. 240, 250-51, 273 N.W.2d 429, 433 (1978); Capan v. Divine Providence Hosp., 287 Pa. Super. 364, 368-70, 430 A.2d 647, 648-50 (1980); Adamski v. Tacoma Gen. Hosp., 20 Wash. App. 98, 112-15, 579 P.2d $970,977-79$ (1978).

22. 33 Ill. 2d 326, 211 N.E.2d 253 (1965), cert. denied, 383 U.S. 946 (1966).

23. Id. at 333,211 N.E.2d at 258.

24. See generally Southwick, The Hospital as an Institution-Expanding Responsibilities Change Its Relationship With the Staff Physician, 9 CAL. W.L. REV. 429 (1973); see also W. IsELE, supra note 8, at 60-67; PRIVATE PRACTICE RePORT, supra note 10, at 16-18 (reflecting physician concerns about encroachment by hospital management on their traditional prerogatives).

25. See, e.g., Elam v. College Park Hosp., 132 Cal. App. 3d 332, 340-47, 183 Cal. Rptr. 156, 161-65 (1982), and cases cited therein. See generally A. SouTHwick, supra note 8, at 409-22. 
facility actively police each other in the interest of the institution. ${ }^{26}$

Another earlier source of conflict between hospitals and doctors was the growth of cost-containment regulation in the 1970's. Most such regulation targeted the hospital, in part because hospital care represented the "big-ticket" item in the overall health care budget, but also because the hospital offered an organizational nexus through which physicians could be pressured to change their spending habits. Certificate-of-need laws were seen both as a way of curbing the effects of unbridled nonprice competition among hospitals for the patronage of doctors and as a way of making it easier for hospital administrators to say "no" to physician demands for more and better facilities. ${ }^{27}$ Such laws were also conceived as a way of limiting the resources available to doctors, thus forcing them to ration care. State programs for fixing hospital rates or revenues were favored for similar reasons. ${ }^{28}$ Indeed, the DRG payment system is only the latest in a series of efforts to control doctors by imposing economic constraints on hospitals. ${ }^{29}$ Over time, as these external constraints have intensified, hospitals have become less and less pliant in their dealings with physicians.

Yet another development that may be changing the tone and character of hospital/physician relations is the expanding role of investorowned hospitals. ${ }^{30}$ These institutions are generally more inclined than

26. Cf. Prybil, supra note 8 , at 81 ("Many boards still shy away from active participation in decision-making that will affect the medical staff.").

27. On certificate-of-need regulation, see infra note 91.

28. On hospital rate-setting, see infra note 37 .

29. On the policy of shifting the rationing burden to providers, see C. HAvigHURST, supra note 1, at 34-38; P. Joskow, Controlling Hospital Costs: THE Role of Government RzgulaTION 31-39, 56-75 (1981); Harris, Regulation and Internal Control in Hospitals, 55 BULL. N.Y. ACAD. MED. 88, 96-101 (1979).

30. On the role of investor-owned hospitals, see generally Clark, Does the Nonprofit Form Fit the Hospital Industry?, 93 HARv. L. REV. 1417, 1440-47 (1980); Relman, The New Medical-Industrial Complex, 303 NEw ENG. J. MED. 963 (1980). The latter article triggered a national debate concerning the role of for-profit firms in the hospital and health care field. See, e.g., HEALTH CARE FOR PROFIT, supra note 6. Among the issues in this debate is the performance of for-profit hospitals in terms of cost and quality. Some evidence supports the assertion that such hospitals chargc higher prices, see, e.g., Pattison \& Katz, Investor-owned and Not-for-profit Hospitals: A Comparison Based on California Data, 309 NEw ENG. J. MED. 347, 352 (1983), but this finding is disputed and may simply reflect higher costs associated with newer facilities or higher quality, see Bromberg, The Medical-Industrial Complex: Our National Defense, 309 NEw ENG. J. MED. 1314, 1314 (1983). Another explanation might simply be the greater skill of profit-seeking hospitals in exploiting poorly designed financing mechanisms. This latter hypothesis, if valid, may be regarded more as a basis for criticizing the flnancing system than as grounds for regulating any particular class of providers. Indeed, much of the debate over the desirability of allowing profit-oriented firms to provide health services focuses ultimately on the question whether substantial reforms of public and private financ. ing mechanisms can and should be expected to curb the propensity of some providers-possibly somewhat more common among proprietary institutions-to overcharge or shade quality. Most of those who oppose for-profit hospitals wish to maintain, even at some cost in inefficiency, a regulated, 
their nonprofit counterparts to insist on their own interests in their various dealings. As long as the system for paying hospitals encouraged hospitals to compete primarily by making themselves as attractive as possible to physicians, for-profit institutions were likely to be especially aggressive and creative in catering to physicians' needs and expectations. ${ }^{31}$ As market conditions change, however, the corporate self-interest of investor-owned institutions should cause them to be quicker than their nonprofit competitors to alter their behavior and to modify their physician staffs' costly styles of practice. Moreover, in a price-competitive world, the presence of aggressive for-profit hospital chains should force nonprofit institutions to become more businesslike in their operations. ${ }^{32}$ In general, it is likely that physicians today are finding all hospitals to be more like traditional business enterprises and less like private clubs than they once may have seemed. ${ }^{33}$

noncompetitive environment conducive to cross-subsidization, see infra note 32, and they apparently believe that their preferred strategy will succeed better if they can exclude those players who are most adept at evading the system's rules and contesting regulatory authority. Although the appeal of a centrally controlled, cooperative system is great, policy is currently evolving in another direction. See supra note 1 and infra text accompanying notes 87-88. Also, it can be asked whether such a system, however well-meaning, could ever truly overcome self-interest and the political forces it spawns. See infra note 33 .

31. Some recent evidence suggests that for-profit hospitals are indeed slightly less likely to restrict their physicians' practice styles. AMA CENTER for Health POLICY RESEARCH, Profit IN Medicine: The Impact on Hospital Staffing Patterns and Physician Practice BehavIOR 3, SMS Report No. 4 (1984), reported in Am. Med. News, Aug. 3, 1984, at 12, col. 1.

32. Although improving efficiency, competition that inspires businesslike behavior by hospitals can have unfortunate side effects on the ability of institutions to cross-subsidize such desirable activities as research, education, and indigent care; some analysts expressly advocate regulation and the suppression of for-profit firms as ways of reducing the threat that competition poses to such internal subsidies. Investor-owned firms have been clearly superior in supplying capital to meet unmet needs and may have some efficiency advantages over nonprofit firms, which may have compensating advantages in appealing to patients and attracting professional personnel. On the considerations that dictate private decisions to adopt the for-profit or the nonprofit form, see Hansmann, The Role of Nonprofit Enterprise, 89 YALE L.J. 835, 840-45 (1980). In accord with Professor Hansmann's analysis, conditions in the health care field strongly suggest that for-profit and nonprofit firms can usefully co-exist as competitors, each with the strengths and weaknesses associated with its particular form of ownership. Indeed, competition between them would appear to be a good way of minimizing the problems that tend to be associated with each type. See C. HAVIGHURST, supra note 1, at 363-75.

33. Although for-profit hospitals may have catered to physicians in the past, see supra note 31 and accompanying text, the medical profession long sought to limit the role of commercial firms in the health care industry. Indeed, physicians' expectation that nonprofit firms would be relatively less inclined to impose controls on medical practice is probably an important reason for the prominence of the nonprofit form in the provision of hospital care and certain forms of health insurance-for example, that offered by Blue Cross and Blue Shield plans. See, e.g., P. Feldstein, Health Care ECONOMICs 194-95 (2d ed. 1979); Majone, Professionalism and Nonprofit Organizations, 8 J. Health Pol., Pol'y \& L. 639, 654-56 (1984); Pauly \& Redisch, The Not-for-Profit Hospital as a Physicians' Cooperative, 63 AM. ECON. REV. 87, 88 (1973). Also, because nonprofit hospitals can attract philanthropy and cannot distribute their surplus earnings, they represent a source of capital that can be invested in facilities whose use is profitable to physicians. Moreover, such hospitals have 


\section{B. Appraising the Balance of Power.}

The powers that hospitals have needed in order to discharge their expanding responsibilities for the quality and cost of care have been acquired largely at the expense of physicians. It is therefore natural to ask whether the balance of power in hospitals is now roughly correct or whether, by some standard, one or the other party exercises undue influence. Not only is this question unanswerable as an abstract proposition, but it is also not a particularly helpful way to formulate or approach the ultimate policy issues. Sound policy would leave the appropriate balance of power in a hospital to be determined in each institution under the constraints that are imposed by external pressures and circumstances. If problems exist-and they do-it is very likely that their true source lies outside the hospital itself. An important thesis of this article is that, with an exception to be elaborated, ${ }^{34}$ how a hospital is internally organized and run should be a managerial issue, not a legal one.

Some clues to power relationships in hospitals may be detected in the work of economists who study and seek to predict hospital behavior. These economists have long been interested in what they call hospitals' "objective function": What goals do hospitals pursue? What do they seek to maximize-the corporation's profits, its budget, its rate of growth, the perquisites, prestige, and job security of management, the health of the community, or something else ${ }^{35}$ Some analyses of these

usually been content to recover their costs and have not insisted on charging profit-maximizing monopoly prices, thus minimizing conflict with physicians over who should reap the scarcity value of facilities used by physicians in providing professional services. In order to prevent physicians from competing away the profits obtainable from selling combined hospital/physician services, medical staffs have employed nonprice rationing systems to allocate use of scarce facilities among their members.

34. See infra text at notes $139-73$ for the argument that hospitals must pay a penalty if they abdicate decisionmaking responsibilities on privileges issues to their medical staffs.

35. Leading economic studies of hospital behavior include P. FELDSTEIN, supra note 33, at 13452; Clark, supra note 30; Clarkson, Some Implications of Property Rights in Hospital Management, 15 J.L. \& ECON. 363 (1972) (contrasting constraints on decisionmakers in nonprofit and in for-profit hospitals); M. Feldstein, Hospital Cost Inflation: A Study of Nonprofit Price Dynamics, 61 AM. EcoN..REV. 853 (1971) (explaining causes of hospital cost inflation); Goldfarb, Hornbrook \& Rafferty, Behavior of the Multiproduct Firm: A Model of the Nonprofit Hospital System, 18 MED. CARE 185 (1980) (multiple objectives of nonprofit hospitals); Jacobs, A Survey of Economic Models of Hospitals, 11 INQUIRY 83, 83-84 (1974); Lee, A Conspicuous Production Theory of Hospital Behavior, 38 S. ECON. J. 48 (1971) (an account of hospital overcapacity and other distortions); Newhouse, Toward a Theory of Nonprofit Institutions: An Economic Model of a Hospital, 60 AM. ECON. REV. 64 (1970) (an economic model of decisionmaking in a private nonprofit hospital); Pauly, Medical Staff Characteristics and Hospital Costs, 13 J. of Human Resources 77 (Supp. 1978); Pauly \& Redisch, supra note 33, at 87 (an economic model of a private, nonprofit hospital); Redisch, Physician Involvement in Hospital Decision Making, in Hospital Cost Containment (1978) (individual decisions shape behavior of hospital "organism"); Saltman \& Young, The Hospital Power Equilibrium: An Alternative View of the Cost Containment Dilemma, 6 J. Health PoL., PoL'y \& L. 391, 396-403 
questions have concluded that, because observed behavior is most consis- tent with a business policy of maximizing physician income, hospital behavior can best be predicted by assuming that physicians are in control. ${ }^{36}$ Although such a conclusion might be viewed as proof of some kind of conspiracy, it does not necessarily establish that the influence of physicians over hospitals is a problem to be remedied by specific intervention. Although physicians may have acted in concert to strengthen their power over the operation of hospitals in the past, changes in the market and legal environment may already be undermining the conditions that made such physician dominance possible.

The obvious benefits that physicians derive from their association with hospitals do not, in themselves, prove the existence of any problems originating within the hospital itself. The conditions that led economists to find that physicians dominate hospital decisionmaking may simply be artifacts of other problems in the health care marketplace whose removal-if they could be attacked directly - would bring about appropriate adjustments in hospital behavior. Until recently, for example, hospitals have had to satisfy their needs for physicians in a market with a constricted supply; it should therefore be no surprise that physicians have benefitted in their bargaining with hospitals. Similarly, because third-party financing has heretofore made it unnecessary for either hospitals or physicians to count costs closely, there has been little reason for hospitals not to gratify doctors' expensive wishes. Finally, because physicians seeking hospital privileges act in important respects as agents of their insured patients-who also are interested in high-quality carewhat appear to be physician gains in bargaining with hospitals may also represent benefits to consumers.

For these reasons, one cannot conclude that the current balance of power within hospitals is itself a significant source of the health care system's difficulties in efficiently allocating societal resources. Of course, if effective competition is lacking or is constrained in the markets in which hospitals and physicians interact, one may reasonably doubt that bargaining between them yields appropriate outcomes and relationships. More importantly, however, the existence of competition in such markets is far from a sufficient condition for efficiency. Indeed, even if we could directly intervene in hospital management to solve any problems that we might find there, we would still have made little progress toward curing

(1981) (advancing a "conflictive equilibrium" model of cost containment); Shalit, $A$ Doctor-Hospital Cartel Theory, 50 J. Bus. 1, 1-2 (1977) (entry barriers in physician and hospital markets).

36. Of the references cited supra at note 35, the works by Clark, Martin Feldstein, Paul Feldstein, Pauly, Redisch, Saltman \& Young, and Shalit tend most strongly toward the conclusion stated in the text. 
the larger problems of distorted incentives and weak price competition that are the product of dysfunctional financing mechanisms. On the other hand, attention to these latter problems would probably go rather far toward stimulating needed changes in the operation of hospitals and in hospital/doctor relations. ${ }^{37}$ As noted earlier, ${ }^{38}$ the important current changes and power shifts in hospitals are direct reflections of external forces that are increasingly impinging upon health care providers.

\section{The Internal Organization of Hospitals.}

Despite the overriding importance of the external environment in shaping power relationships within hospitals, a look inside the hospital reveals some problems that may not yield readily to outside pressures and market forces. Economist Jeffrey Harris has observed that there is an almost complete separation in hospitals of what he calls the "revenue centers," which physicians control, from the "cost centers," which are the province of hospital administrators. ${ }^{39}$ Harris notes that the institutionalized barriers he perceives between those whose decisions generate demands on the hospital and those who must provide the resources to meet those demands create severe difficulties for hospitals in their efforts to control their costs. The separation of hospital and physician decisionmakers is strongly reinforced by the convention of billing patients separately for hospital care and for physician services and by the existence of a self-governing medical staff. Because the medical staff elects its own officers, appoints the committees that oversee physician activities in the hospital, and makes authoritative recommendations on the avard, denial, or revocation of admitting privileges, individual physicians are accountable in the first instance to each other rather than directly to the

37. Theoretically, of course, stringent rate or revenue regulation could also force hospitals to strive for efficiency. See P. Joskow, supra note 29; P. FELDSTEIN, supra note 33, at 260-311. Nevertheless, although regulation could substantially limit the resources available to hospitals, it may not do so in practice. Moreover, regulation is unlikely to diminish physician influence over the allocation of those resources. See authorities cited supra note 29. Regulation also limits the opportunities of consumers to express their own preferences. For a critical view of cost-containment regulation, see C. HAvighurst, supra note 1, at 25-50; Havighurst, Book Review, 18 HEALTH SERV. Res. 93 (1983) (reviewing P. Joskow, Controlling Hospital Costs: The Role of GovernMENT REGULATION (1981)).

38. See supra notes 1-6, 14-33 and accompanying text.

39. Harris, supra note 29 at 90-95. See also P. Joskow, supra note 29, at 31; Harris, The Internal Organization of Hospitals: Some Economic Implications, 8 BELL J. EcoN. 467 (1977). Harris describes the typical hospital as "two firms loosely connected by a complex set of nonmarket relations"; one arm of the "split organization" supplies what the other, the medical staff, demands. Id. at 470-72. For sociological views of hospital organization confirming this dichotomy, see Goss, Patterns of Bureaucracy Among Hospital Staff Physicians, in THE HOSPITAL IN MODERN SOCIETY 170 (E. Freidson ed. 1963); Smith, Two Lines of Authority-The Hospital's Dilemma, in PaTIENTS, PhysiCIANS AND Illness 468, 468-71 (E. Jaco ed. 1958). 
institution. As a freestanding, self-governing administrative unit, the medical staff has few parallels in other organizations. Academic departments in universities exercise comparable "peer review," but professors cannot readily take their students elsewhere and are subject to control by centrally-appointed chairmen and deans with authority over their compensation. A hospital staff is much better positioned to exert collective influence over institutional policies that affect professional interests.

It is paradoxical that the sharp separation of operational responsibilities within hospitals results in part from what may be regarded as an undue closeness in policymaking between the typical hospital governing board and the medical staff. It is widely suspected that many hospital boards, particularly in nonprofit institutions, while retaining formal power, have effectively yielded much of their decisionmaking authority on a wide range of issues to the medical staff. 40 If it is true that hospitals defer to physicians and seldom actively assert their independent and sometimes conflicting interests, it would follow that hospitals' internal structures and operations excessively reflect the preferences of physicians. On the other hand, as hospitals face increasing cost pressures, they are likely to reclaim some of their lost or shared authority. They may also then proceed to reorganize themselves in more efficient ways, perhaps breaking down the extreme separation of functions that Harris observes. Whether public policymakers need to focus any special attention on hospitals' decisionmaking mechanisms or organizational structures depends upon whether hospitals face any artificial constraints in reshaping themselves to realize their corporate purposes. An answer to this latter question may perhaps be found by inquiring further into why hospitals are organized as they are.

Although Harris notes that one could attribute the extreme separation of responsibilities in hospitals to a desire "to perpetuate an organized medical monopoly," 41 he sees a more benign explanation. Adopting a perspective very similar to that taken by economist Kenneth Arrow in a well-known 1963 article, ${ }^{42}$ Harris attributes the hospital's internal structure to the special nature of medical care, particularly to the ethical dimension of the doctor/patient relationship and to the need, especially in acute-care hospitals, to cope rapidly with complexity and uncertainty without pausing to calculate benefit/cost ratios. Harris's interpretation may owe something to the fact that he has been trained in medicine as

40. See supra note 26 . On nonprofit hospitals, see supra notes 30-33.

41. Harris, supra note 39 , at 474.

42. Arrow, Uncertainty and the Welfare Economics of Medical Care, 53 AM. ECON. REv. 941 (1963) (ascribing the special economics of medical care to uncertainties attending disease and its treatment). 
well as economics. This unusual perspective may enable Harris to see values that escape more cynical observers, but it may also make him less inclined to question the motives that caused hospitals to be organized in a way that makes them systematically neglectful of the cost factor. In any event, Harris never clearly asks why internal hospital arrangements such as those that he himself proposes as reforms never evolved spontaneously.

Harris's attribution of the prevailing organizational pattern in hospitals to patient care considerations seems subject to much the same criticism that sociologist Paul Starr has offered of Arrow's earlier expression of admiration for the systematic subversion of market forces that he observed in medical care. ${ }^{43}$ Arguing that Arrow indulged an unwarranted presumption that market forces were dampened in response to a true social need-apparently by some benign, nonmarket invisible hand-, Starr concludes that the result of Arrow's analysis "is not so much to explain as to explain away the particular institutional structure medical care has assumed in the United States." 44 Harris, though noting the need for organizational changes in hospitals, is similarly uncritical of the process by which hospitals came to be organized as they are. In short, neither Arrow nor Harris adequately recognizes that the financing and organizational arrangements they investigated were in large part designed and forced upon the system by organized medicine. It seems probable that a major goal of dominant professional interests in designing these institutional frameworks was to insulate physicians as much as possible from cost and competitive pressures. ${ }^{45}$

43. P. STARR, supra note 1 , at 225-27.

44. Id. at 227.

45. See id. at 21-29. The free-standing, self-governing character of the traditional medical staff makes it difficult for a hospital to implement policies that conflict with staff interests. See supra note 12. If the hospital rather than the staff assigned individual physicians to supervisory roles, it could exercise its authority directly and presumably would not have to negotiate with a unified staff over every issue. Ultimately, of course, it is an empirical question how much difference the organizational form makes. See infra note 141 for references on the factual issue of staff control over the award of privileges. Negotiation would occur in either setting, and an organized staff lacks, at least as a matter of law, the ultimate sanction of the power to strike. See infra text accompanying notes 75-78. But physicians have been anxious to preserve the staff's traditional status. See, e.g., Medical Staff Autonomy Dominant Section Issue, Am. Med. News, June 29-July 6, 1984, at 3, col. 1; Private PRACTICE REPORT, supra note 10. Other signs also suggest that the matter has been of considerable importance in weakening the authority of hospitals and in protecting the de facto sovereignty that physicians enjoy in the absence of intermediaries capable of serving as knowledgeable purchasing agents for the consumer. See generally P. STARR, supra note 1, at 162-79, 215-32, 428-49 ("The hospital . . . did not stand between the doctors and the market. On the contrary, the doctors came to stand between the hospital and its market." Id. at 218.) It is apparent that rationalization of health care in the present environment requires that hospitals have some freedom to adopt arrangements that alter traditional power relationships. 
The organizational characteristics noted by Harris are not the result of considered choices by hospital managers about how best to organize and operate a hospital. Nor is the reason why nearly all hospitals are organized in essentially the same fashion to be found in the operation of the market's invisible hand. Instead, it appears that hospitals' internal structures have been prescribed by the Joint Commission on Accreditation of Hospitals (JCAH), a body dominated by representatives of powerful medical organizations. ${ }^{46}$ In addition to mandating the existence of a self-governing medical staff, 47 JCAH accreditation standards contemplate essentially the same departmental configuration that Harris finds inefficient in performing the task of cost containment. ${ }^{48}$ Although this internal structure probably could not have been imposed on hospitals if external conditions had been substantially different, the medical profes-

46. See generally Jost, The Joint Commission on Accreditation of Hospitals: Private Regulation of Health Care and the Public Interest, 24 B.C.L. REV. 835 (1983). The rise of the medical staff as a distinctive feature of the internal organization of the hospital is generally dated from around 1920 . This ascendancy apparently was not guided by any significant theory of the legal nature of the medical staff. See M. RoEMER \& J. FriedMAN, supra note 7, at 36-39; P. STARR, supra note 1, at 161-69. Starr traces the transformation of the hospital from a charitable institution, largely serving the needy at no cost and with few physicians, to the modern hospital. He writes,

While doctors' access to hospitals expanded, professional associations sought ways to tighten the medical organization of hospitals. In 1919, as part of a campaign to assure minimum standards for hospital care, the recently established American College of Surgeons adopted a requirement that hospitals wishing to receive its approval organize their affiliated physicians into a "definite medical staff."

Id. at 167. The AMA in the same year set minimum standards for hospital internships, with the result that, "though compliance with these normative bodies was voluntary, they pushed hospitals toward a more formally structured, hierarchical organization." Id.; see also Jost, supra, at 847-49 (tracing history of the American College of Surgeons).

47. Until a recent revision, the JCAH Manual provided that the "medical staff shall develop and adopt bylaws, rules and regulations to establish a framework of self-government and a means of accountability to the governing body." 1984 MANUAL, supra note 8, at 98 . In a subsequent rewriting of the section on "Medical Staff'-not yet incorporated in the Manual but available from the JCAH and on file with the author [hereinafter cited as Revised Medical Staff Standards]-, the explicit reference to self-government was dropped. Although the new version appears still to contemplate that the staff would select its own leaders, it provides, in a surprising passage, that the executive committee of the medical staff, instead of being selected by the staff itself, may be "appointed in accordance with governing body by-laws." Revised Medical Staff Standards, supra, at 3. This contrasts strikingly with the following in the 1984 MANUAL, supra note 8, at 97: "The medical staff bylaws shall define the size, composition, and method of selection of members of the executive committee. The chairman and members should not ordinarily be appointed by the governing body or chief executive officer. Representation of all staff members should be assured." Hospitals would thus seem to have new room to maneuver in relating to physicians. This impression is confirmed by the rewriting in the 1984 MANUAL of the section on the "Governing Body." Compare 1984 MaNUAL, supra note 8, at 49-51 (stating general goals), with JCAH, ACCREDITATION MANUAL FOR Hospitals/1983 51-56 (rev. ed. 1982) [hereinafter cited as 1983 MANUAL] (stating specific required interactions between medical staff and board).

48. Harris, supra note 39 , at $471 \&$ n.4. The departmental configuration diagrammed by Harris, $i d$. and supra note 29 , at 91 , is refiected in the departmental breakdown in the 1984 MANUAL, supra note 8 . 
sion apparently exercised enough control over the payment system ${ }^{49}$ and the physician supply ${ }^{50}$ to permit physicians to obtain hospital privileges on their desired terms. We should not be surprised to find that hospitals, as designed by the JCAH, unduly serve the interests of physicians.

Legal requirements, though important, do not appear to have been the dominant factor determining the internal organization of hospitals. Statutes that today require hospitals in some states to maintain a selfgoverning medical staff appear to have been enacted only after that model became dominant. ${ }^{51}$ Perhaps the most important legal influence in the early days were legal rules restricting in varying degrees the corporate practice of medicine. ${ }^{52}$ Nevertheless, although these rules barred

49. On the influence of organized medicine over the design and administration of private health insurance, see Michigan State Medical Soc'y [1979-1983 Transfer Binder] Trade REg. REP. (CCH) I 21,991 (Feb. 17, 1983) (final order to cease and desist); FTC, Physician Agreements to Control Medical Prepayment Plans, 46 Fed. Reg. 48,982 (1981); FTC, Staff Report and Proposed Trade Regulation Rule, Medical Participation in Control of Blue Shield and Certain Other Open-Panel Medical Prepayment Plans (1979); P. Starr, supra note 1, at 299310; Goldberg \& Greenberg, The Effect of Physician-Controlled Health Insurance: U.S. v. Oregon State Medical Society, 2 J. Health PoL., PoL'Y \& L. 48 (1977); Havighurst, Professional Restraints on Innovation in Health Care Financing, 1978 DuKE L.J. 303; Note, The American Medical Association: Power, Purpose, and Politics in Organized Medicine, 63 YALE L.J. 938, 980-88 (1954).

50. See, e.g., M. Friedman, Capitalism and Freedom 149-54 (1962); Kessel, The AMA and the Supply of Physicians, 35 LAW \& CONTEMP. ProBS. 267 (1970). As noted, supra text accompanying note 17 , the supply situation has greatly changed in recent years, largely as a result of government intervention.

51. See, e.g., CAL. Health \& SAFETy CODE $\S 32128$ (West Supp. 1984) (originally enacted as 1949 Cal. Stat. ch. 919, § 3). Such laws may have been enacted because professional interests were concerned about persistent deviations by smaller, unaccredited institutions from the model favored by the profession.

52. See generally Forgotson, Roemer \& Newman, Innovations in the Organization of Health Services: Inhibiting vs. Permissive Regulation, 1967 WASH. U.L.Q. 400, 402-08 (1967); Hansen, Laws Affecting Group Health Plans, 35 Iowa L. Rev. 209, 211-19 (1950); Laufer, Ethical and Legal Restrictions on Contract and Corporate Practice of Medicine, 6 LAW \& ConTEMP. ProBs. 516 (1939); Willcox, Hospitals and the Corporate Practice of Medicine, 45 CoRNell L.Q. 432 (1960); Note, 48 YALE L.J. 346 (1938). As of 1967, rules prohibiting the corporate practice of medicine existed in all states except Missouri and Nebraska. Forgotson, Roemer \& Newman, supra, at 402. The rule still exists in some form in many states. See, e.g., State v. Abortion Information Agency, Inc., 37 A.D.2d 142, 143, 330 N.Y.S.2d 927, 928 (1971), affd, 30 N.Y.2d 779, 285 N.E.2d 317, 334 N.Y.S.2d 174 (1972); CoLo. Rev. STAT. § 12-36-117(1)(m) (Supp. 1983); GA. Code ANN. § 43-3437(a)(9) (1982).

The reasons most often given for the rnle are well summarized in a recent California Attorney General's opinion:

[F]irst, that the presence of a corporate entity is incongruous in the workings of a professional regulatory licensing scheme which is based on personal qualification, responsibility and sanction, and second, that the interposition of a lay commercial entity between the professional and his/her patients would give rise to divided loyalties on the part of the professional and would destroy the professional relationships into which it is cast.

65 Op. Att'y. Gen. 223, 225 (Cal. 1982) (emphasis in original). In some jurisdictions the corporate practice rule precludes for-profit but not nonprofit corporations from offering professional services. See, e.g., id.; ARIZ. REv. STAT. ANN. §§ 20-821, 20-822 (1975 \& Supp. 1983); see also Forgotson, Roemer \& Newman, supra, at 403-04; Willcox, supra, at 444-49. 
hospitals in some states from providing professional services to patients through their own employees, ${ }^{53}$ they did not make it inevitable that lay hospital boards would create a self-governing medical staff and delegate to it substantial responsibility for medical matters. ${ }^{54}$ There were other organizational arrangements-intermediate between direct employment of physicians and reliance upon an independent medical staff-that hospitals could lawfully have adopted to carry out their corporate purposes. For example, a hospital might have integrated its cost and revenue centers, hired physicians to administer its operating units, and contracted directly with individual physicians desiring to use the facility. Instead of relying upon a freestanding medical component to provide peer review, a hospital might have empowered its own physician administrators to oversee a physician's practice in the interest of quality assurance and cost containment. ${ }^{55}$ The almost universal neglect of such alternatives for efficiently organizing a hospital without a self-governing medical staff

53. See, e.g., MONT. CODE ANN. § 37-3-322(15) (1983); UTAH CODE ANN. § 58-12-36(9) (1953 \& Supp. 1983). In both Montana and Utah "unprofessional conduct" is defined to include doctors practicing medicine as the partner, agent, or employee of, or in a joint venture with, a person who does not hold a license to practice. This would seem to preclude doctors from becoming employees of hospitals or other corporations.

The controversy over hospital employment of physicians has focused on pathologists, radiologists, and anesthesiologists. R. Schulz \& A. JoHNSON, MANAGEMENT OF Hospitais 93-95 (2d ed. 1984). Many state court decisions and attorney general opinions in the 1930's, 1940's, and 1950's found that these specialists could not be employees of hospitals, often citing statutes barring the corporate practice of medicine. See, e.g., 1954 Op. Iowa Att'y. Gen. 122; 11 Op. Att'y. Gen. 236, 236 (Cal. 1948). Today some states that still prohibit the corporate practice of medicine make a specific exception allowing hospitals to employ physicians. See, e.g., GA. CoDE ANN. § 43-3437(a)(9) (1982). The conflict between the hospitals' need for physician employees and the ethic of the physician as independent practitioner led to legal relationships that maintained the nominal independence of the specialist in-house physician while keeping him in fact full-time in-house. See, e.g., $1955 \mathrm{Op}$. Idaho Att'y. Gen. (making the physician a tenant of the hospital and allowing the hospital to collect fees while avoiding control of the physician); see generally P. STARR, supra note 1, at 221-25; Forgotson, Roemer \& Newman, supra note 52, at 403-04.

As many as half of all physicians may receive some part of their income in the form of a salary. Kahn \& Orris, The Emerging Role of Salaried Physicians: An Organizational Proposal, 3 J. PuB. HEALTH Pol'y 284 (1982); see also Friedman, Salaried Doctors, HosP. MED. STAFF, Aug. 1983, at 11.

54. Where not prohibited by law, a hospital might employ its physicians and still permit them to organize a self-governing staff and to exercise important corporate powers. Indeed, the corporatepractice rule may prevent the formation of a normal employer-employee relationship, requiring that the physician be free of corporate control. The JCAH, which presumably is concerned about preserving professional independence, accredits many institutions whose physicians work for a salaryfor example, the prestigious Henry Ford Hospital in Detroit.

55. Such an arrangement might run afoul of the corporate-practice rnle as applied in some states, but other states would probably tolerate it, at least if the hospital were a nonprofit firm. The argument in the text is not that alternatives to the traditional model are always lawful but that they are not so widely prohibited as to account for the virtual unanimity of hospitals in permitting physicians to elect their own leaders and to act collectively as a freestanding unit within the larger enterprise. 
strongly suggests that the medical profession, working largely through the JCAH in recent years, has effectively dictated the essential terms upon which hospitals may deal with physicians. ${ }^{56}$

Although the JCAH has been effective in protecting physician interests in the past, it may be less so in the future. At least partly out of fear of antitrust liability, it has already changed one of its most controversial protective standards, which required hospitals to exclude nonphysician providers from eligibility for admitting privileges. ${ }^{57}$ Moreover, the influence of the accrediting program may be reduced as a result of recent antitrust scholarship pointing out flaws in the constitution of the JCAH. ${ }^{58}$ Finally, whatever may happen on the antitrust front, the

56. Although one cannot absolutely rule out the possibility that the dominant model is dominant because it is the most efficient, hospitals have had little freedom to experiment. It is true that a hospital, to be accredited by the JCAH, "need not be in full compliance with each applicable standard." 1984 Manual, supra note 8, at xiv. Despite the possibility of departures from the profession's preferred model, however, it still seems certain that accreditation rules have inhibited many institutions, especially smaller, less prestigious ones, from even considering alterations in their traditional arrangements with physicians.

57. 1984 MANUAL, supra note 8 , at $97-98$. In late 1983, the JCAH revised its standards governing the medical staff, see supra note 47 , to provide that the medical staff "includes fully licensed physicians and may include other individuals permitted by law and by the hospital to provide patient care services independently in the hospital"; it also permitted, for the first time, the granting of clinical privileges to nonphysicians. See JCAH Medical Staff Standards Approved, Am. Med. News, Dec. 23-30, 1983, at 1, col. 3. Allowing nonphysicians to practice independently in the hospital had been the subject of a long legal battle. See, e.g., Levin v. JCAH, 354 F.2d 515, 517 (D.C. Cir. 1965) (two podiatrists who had been allowed unsupervised surgical privileges in a hospital challenged the JCAH's efforts to impose medical supervision by members of the medical staff); see also W. ISELE, supra note 8, at 91-113; Jost, supra note 46, at 859 n.217 \& 873 (listing cases); Allied Health Workers Seek Staff Privileges, Am. Med. News, Nov. 25, 1983, at 2, col. 1. The old JCAH standard was the subject of an antitrust challenge on behalf of clinical psychologists in Ohio v. JCAH, Civ. No. C-279-1158 (S.D. Ohio, filed Dec. 14, 1979) (later dismissed as moot).

Other JCAH standards that may have been equally designed to protect physician interests may be less vulnerable to antitrust attack because no identifiable group or individual is specifically victimized. For example, the requirement of a self-governing medical staff is unlikely to be directly challenged, although in one interesting case the attorney general of Maryland forced a change in a hospital's bylaws to ensure that the governing board, not the medical staff, would control the award of staff privileges. Hospital Board to Rule on Privileges, Am. Med. News, Mar. 5, 1982, at 1, col. 1 .

For the view that challenges to specific standards are the wrong way to address problems in credentialing and accrediting, see Havighurst \& King, Private Credentialing of Health Care Personnel: An Antitrust Perspective (pts. 1 \& 2), 9 AM. J. L. \& MED. 131, 263 (1983). Perhaps surprisingly, that article argues, id. at 183, 330, that the plaintiff's challenge in Ohio v. JCAH should have been rejected. It offers, however, a much morc fundamental challenge to the JCAH and comparable bodies. See id. at 323-25 (discussed infra note 58).

58. See Havighurst \& King, supra note 57, at 314-25, which suggests the illegality under the Sherman Act of a number of joint credentialing and accrediting boards, including the JCAH. The argument in the case of the JCAH is that, as a joint venture of four powerful physician and hospital organizations, it suppresses important diversity-i.e., competition-in the production of information and opinion potentially useful to consumers and others in purchasing hospital services. But see Jost, supra note 46, at 903-04 (suggesting that the JCAH is a combination whose actions are subject to close scrutiny, but failing to recognize the restraint occurring in the market for information). 
changing economic environment could induce an increasing number of hospitals to design their future arrangements with doctors without regard to JCAH requirements. ${ }^{59}$ Thus, a hospital might decide to rewrite its medical staff's bylaws without the staff's consent even though that act would jeopardize the hospital's accreditation. ${ }^{60}$ Another hospital, facing financial difficulties and probable loss of accreditation for quality deficiencies, might elect to adopt organizational reforms of which it knows the JCAH will disapprove. In short, growing economic pressures, coupled with changes in the accrediting system itself, could eventually inspire a significant number of hospitals to alter those arrangements mandated by the JCAH that have heretofore insulated individual physicians from direct accountability to the hospital.

The possibility that decisionmaking in hospitals is unduly dominated by physicians is a policy problem that cuts across the entire spectrum of hospital behavior, eventually linking up with major concerns about whether society's scarce resources are being diverted from their best uses into wasteful forms of health care. Although solutions to the overall resource-allocation problem must be pursued primarily through incentive-oriented reforms that go beyond the context of the hospital itself, such reforms should be accompanied by careful attention to any legal, regulatory, and extralegal constraints that prevent or discourage hospitals from making organizational changes that might better facilitate the translation of consumer preferences into provider behavior. It goes almost without saying that statutes directly regulating hospitals' arrangements with physicians, and judge-made rules restricting the corporate practice of medicine and the direct employment of physicians, may no longer be appropriate limitations on the freedom of hospitals to organize

59. If large numbers of hospitals begin to ignore particular JCAH standards, the JCAH might seek to maintain its influence by changing the standards or by not enforcing them. See supra note 56.

60. Courts in several jurisdictions have held that medical staff bylaws constitute a binding contract between the hospital and medical staff. See, e.g., McMillan v. Anchorage Community Hosp., 646 P.2d 857, 861 (Alaska 1982); Joseph v. Passaic Hosp. Ass'n, 26 N.J. 557, 569, 141 A.2d 18, 25 (1958); St. John's Hosp. Medical Staff v. St. John Regional Medical Center, 90 S.D. 674, 679-81, 245 N.W.2d 472, 474-75 (1976). Contra, e.g., Shulman v. Washington Hosp. Center, 319 F. Supp. 252, 255 (D.D.C. 1970); Ponca City Hosp., Inc. v. Murphree, 545 P.2d 738, 742 (Okla. 1976); State ex rel. Wolf v. LaCrosse Lutheran Hosp. Assoc., 181 Wis. 33, 35, 193 N.W. 994, 996 (1923). The JCAH once threatened to revoke the accreditation of a hospital if the governing board "adopts and tries to enforce bylaws that the staff hasn't approved." Martin, Doctors vs. Hospitals: A New Deal for Medical Staffs, MED. ECON., Mar. 3, 1975, at 35. Recently the AMA House of Delegates adopted a board report recommending that medical staffs "develop bylaw provisions that affirn the binding effect of medical staff bylaws on both the hospital governing board and the medical staff." Closed Medical Staff Issue to be Studied, Am. Med. News, June 29-July 6, 1984, at 37, col. 1. See also W. ISELE, supra note 8, at 34-44; PRIVATE PRACTICE REPORT, supra note 10, at 10-18; Horty \& Mulholland, The Legal Status of the Hospital Medical Staff, 22 ST. Lours U.L.J. 485, 494-96 (1978). 
themselves to meet the challenges that public policy is asking them to meet. ${ }^{61}$ Other legal constraints to which hospitals are subject in their dealings with physicians are examined in the remainder of this article.

\section{The Hospital Medical Staff in Antitrust Perspective}

Aside from those statutes and rules that directly regulate the internal organization of hospitals, most of the law governing hospital/physician relationships concerns the award or denial to practitioners of admitting privileges. However, because the self-governing medical staff found in the typical modern hospital is a combination of competing physicians, all of its activities are subject to legal scrutiny under section 1 of the Sherman Act. ${ }^{62}$ Thus, although admitting privileges are the main topic of this article, it is important at the outset to understand the antitrust rationale under which a medical staff is permitted to exist and the substantial limitations which that rationale places upon the staff's activities and methods of operation. The legal doctrines introduced here will reappear at later points.

61. This is not the place to argue the full case against the corporate-practice rule and its variations that limit the ability of hospitals to control the quality and cost of care provided on their premises. It suffices to say that, like statutory and common-law rules protecting physicians against unfair denial of their supposed right to practice in the hospital of their choice, these rulcs are the product of an era in which public policy looked to the medical profession and public licensure to protect the public interest and did not contemplate a meaningful role for consumer choice, price competition, or corporate middlemen. See Rosoff, The "Corporate Practice of Medicine" Doctrine: Has Its Time Passed?, HealTh L. D1G. (Supp.), Dec. 1984, at 1, 1.20; see also infra notes $82-94$ and accompanying text. Now that consumers and government are looking to hospitals to control both the quality and cost of care in an environment marked by competition and informed consumer choice—-often exercised on the consumer's behalf by knowledgeable agents, such as employers and insurers-, legal restrictions on hospitals' freedom to establish efficient arrangements with physicians seem out of place. On the larger question whether competing corporate intermediaries are trustworthy as agents of health care consumers-or, more precisely, are more reliable than noncompeting physicians as instruments for optimizing private spending on health care services-, sce the conclusion of this article. In any event, current public policy appears to undermine the premises of old legal doctrine by looking explicitly to competing hospitals to act as independent decisionmakers accountable in the marketplace to both consumers and physicians.

62. The statute reads, "Every contract, combination . . . or conspiracy, in restraint of trade or commerce . . . is declared to be illegal." 15 U.S.C. $\$ 1$ (1982). In Weiss v. York Hosp., 745 F.2d 786,814 (3d Cir. 1984), the court held that, "as a matter of law, the medical staff is a combination of individual doctors and therefore, that any action taken by the medical staff satisfies the "contract, combination, or conspiracy' requirement of section 1."

A recent privileges case finds an implied exemption from the Sherman Act for medical staff activities carried out under a pervasive state scheme of medical peer review. Marrese v. Interqual, Inc., 748 F.2d 373, 394 (7th Cir. 1984). The court's finding, id. at 390-91, that the staff's activities were supervised actively enough by the state to obviate antitrust concerus and to satisfy the requirements of California Retail Liquor Dealers Ass'n v. Midcal Aluminum, Inc., 445 U.S. 97, 105.06 (1980) (limiting state-action immunity to restraints explicitly avowed and actively supervised by the state itself) seems far-fetched. 
A hospital medical staff is organized at the invitation of a hospital, which looks to it to perform a variety of services vital to the hospital's overall health care mission. As one element in a larger enterprise that must compete with other comparable enterprises, the staff has a clear procompetitive impact. Moreover, the hospital/staff arrangement, by combining the hospital's resources with the professional skills of physicians, yields important efficiencies. For these reasons, medical staffs are presumptively entitled to have their anticompetitive aspects judged under the antitrust laws as so-called ancillary restraints of trade-that is, as incidental restraints helpful in accomplishing a joint venture's legitimate business objectives. ${ }^{63}$ Even though most restraints will be upheld if they serve procompetitive purposes, a legal problem may still exist if the scale of the activity or some other special circumstance causes the competitors' otherwise lawful joint action to jeopardize competition in the larger market. ${ }^{64}$ But, if the physicians constituting a hospital's medical staff do not collectively possess a high market share ${ }^{65}$ or control access to resources

63. The validity of certain ancillary restraints was first elaborated in a famous opinion by Judge William Howard Taft, United States v. Addyston Pipe \& Steel Co., 85 F. 271, 282-86 (6th Cir. 1898), aff'd and modified, 175 U.S. 211 (1899). Although the Supreme Court has not explicitly built upon Judge Taft's useful distinction between ancillary and "naked" restraints, it has recently reiterated it. See National Soc'y of Professional Eng'rs v. United States, 435 U.S. 679, 689 (1978). Moreover, the concept continues to have substantial analytical and explanatory value. See, e.g., Bork, The Rule of Reason and the Per Se Concept: Price Fixing and Market Division (pts. 1 \& 2), 74 YALE L.J. 775, 776-77 (1965), 75 YALE L.J. 373, 465-73 (1966).

It is submitted that the simplest way to detect an arguably ancillary restraint is to ask whether the ostensible purpose of the arrangement limiting competition is one that could be achieved even if the collaborators collectively possessed no market power-that is, lacked the ability to lessen the vigor of competition throughout a correctly defined market. Because the ability of a medical staff to control the quality of care within a single hospital does not depend at all upon any ability to limit the play of competitive forces, any restraints it imposes, see, e.g., infra text accompanying note 69, are ancillary ones. On the other hand, a county medical society that seeks to maintain the quality of care in the community by an ethical rule against, say, the prescription of Laetrile imposes a naked restraint. See Havighurst, supra note 49 , at 353 n.214. The key distinction is that the medical society, unlike the medical staff, is not part of an integrated business enterprise subject to competition from other such enterprises. See Arizona v. Maricopa County Medical Soc'y, 457 U.S. 332, 356-57 (1982) (medical organizations found not to be integrated joint ventures producing a new product or service and therefore are subject to per se rule applicable to competing entrepreneurs).

64. Although competitors are not automatically barred from combining to pursue any purpose whose accomplishment does not require the possession of market power, see supra note 63, a dilemma is presented if they possess market power in fact. If their collective power is likely to make the net effect of their collaboration harmful to competition, it could be appropriate under the rule of reason to deny them the right to organize on that scale, even for a potentially useful, efficiencypromoting purpose. Merger law, embodying essentially the same rationale, may sometimes condemn a combination because of undue concentration even at the risk of sacrificing some efficiency. See Department of Justice, Statement Accompanying Release of Revised Merger Guidelines, 49 Fed. Reg. 26,823, 26,827 (1984) (efficiencies are cognizable but not controlling).

65. Under the principle stated supra note 64 , antitrust law might be construed to prohibit the organization of a medical staff comprising a very large percentage of local physicians. However, because the members of a medical staff continue to compete with each other in numerous respects, 
needed by others to compete effectively in the market, ${ }^{66}$ their collaboration presents no danger at all to competition and thus should give rise to no antitrust problems. ${ }^{67}$

Even if a potential danger to competition can be identified, a court's warrant under antitrust law's "rule of reason" is only to ascertain whether the joint venture's anticompetitive effects outweigh its procompetitive features. ${ }^{68}$ Thus, if a medical staff's organization and operation are reasonably well tailored to accomplish legitimate hospital objectives, there should be no antitrust objection to the staff's formation even if the staff could collectively exercise market power due to the absence of other hospitals or physicians in the area. Furthermore, specific activities of the staff that adversely affect competition could survive attack under a rule of reason analysis. For example, limitations imposed by the staff on its members' surgical privileges, though technically a division of markets and a per se violation when imposed as a naked restraint, ${ }^{69}$ might be justified by reference to the hospital's competitive incentive-not to men-

the dangers to competition from permitting them to organize under a hospital's auspices would probably not be found to outweigh the procompetitive benefits. Nevertheless, it bears remembering that there exists a legal theory, see supra note 64 , under which the sole hospital in an area, if it could lawfully and effectively carry out its functions without creating an organized medical staff, could bc required to do so. See infra text accompanying note 192. As later discussion will show, see infra text accompanying notes 180-81, a court's inclination, even where such a structural solution might be possible and neater, would probably be to regulate a powerful group's conduct toward its competitors by insisting on faimess and by reviewing the actions taken for substantive validity. The analysis in this article points away both from a rigorous structural approach and from an overly regulatory approach, and toward the more modest requirement that a hospital that authorizes its staff to organize must maintain effective oversight of staff activities dangerous to competition.

66. Later discussion recommends applying the so-called "essential-facilities" doctrine to a medical staff exercising such power. See infra text accompanying notes 122-73.

67. To be deemed procompetitive, an ancillary restraint must be reasonable-that is, not materially broader than necessary to accomplish the venture's legitimate purposes. Overbreadth may be taken as a sign that the ostensible purpose was not the real one, making the restraint a naked one after all. See, e.g., Timken Roller Bearing Co. v. United States, 341 U.S. 593, 597-99 (1951) (invalidating agreements that "went far beyond" protection of a trademark). Or a court might conclude that, because the collaborators' legitimate purposes could have been achieved by means of a "less restrictive alternative," see infra text accompanying notes 184-88, the joint arrangement unnecessarily endangers competition to an extent outweighing its benefits. The law remains unclear whether ancillary restraints can be condemned under these principles without a speeific finding that the parties possess enough market power in a properly defined market to endanger competition in fact. See supra note 64. A technical inquiry into this complex question would probably be undertaken only if the restriction were not of a type that would be classed as a per se violation when it appears in a naked form. The so-called per se offenses are those restraints that have been deemed by the courts to be so dangerous to competition that proof of their actual effects on competition in a particular case is not required. See infra note 121 .

68. See supra notes 64-65.

69. Market division is normally a per se violation. United States v. Topco Assocs., Inc., 405 U.S. 596, 608 (1972); see Timken Roller Bearing Co. v. United States, 341 U.S. 593, $595-97$ (1951) (invalidating division of world markets). Where undertaken by a joint venture for procoinpetitive purposes, however, it should be evaluated under the rule of reason. But see infra note 70. 
tion its legal duty-to ensure that staff surgeons are competent to perform the tasks they undertake. ${ }^{70}$ Other staff activities related to quality assurance and cost containment should be similarly defensible by reference to the hospital's business and competitive interests. Later analysis of how admitting privileges should be administered suggests more precisely how a hospital and its medical staff must coordinate their efforts in order to minimize antitrust problems.

It is notable that the self-policing activities of a medical staff are upheld only because they promote competition and efficiency, and not because they are in some other sense "in the public interest" or because they are undertaken by professionals, as distinct from ordinary businessmen. ${ }^{71}$ Antitrust law does not, as a general rule, tolerate competitor collaboration simply because it serves worthy purposes, professional or otherwise. $^{72}$ Instead, the legal inquiry under the rule of reason focuses on whether a particular collaboration is compatible with the maintenance of competition in the market as a whole. ${ }^{73}$ It is nevertheless usually the

70. Under existing precedent, the case might not be as easy as it should be, however, because courts have been reluctant to permit as an ancillary restraint conduct that has been classed as a per se violation when found in a naked form. In such a case, a court might condemn the conduct upon a suggestive showing of market power without further inquiry. See supra notes $64,65 \& 67$. The most troubling precedent in this regard is United States v. Topco Assocs., Inc., 405 U.S. 596 (1972), which is discussed critically infra note 113. By extension of this article's legal conclusions regarding denials of staff privileges, an antitrust court should insist that a hospital exercise some independent oversight of privilege limitations. Hospital involvement provides some assurance that such restrictions serve hospital objectives and not those of the medical staff alone. See infra text accompanying notes $139-73$.

71. See infra text accompanying notes 95-102.

72. See, e.g., National Soc'y of Prof. Eng'rs v. United States, 435 U.S. 679, 691 (1978) (vigorously rejecting a worthy-purpose defense and framing the question as whether competitor collaboration "merely regulates and perhaps thereby promotes competition or whether it is such as may suppress or even destroy competition," quoting Chicago Bd. of Trade v. United States, 246 U.S. 231, 238 (1918)); see also NCAA v. Board of Regents, 104 S. Ct. 2948, 2960 n.23 (1984) ("Good motives will not validate an otherwise anticompetitive practice."). In the latter case, however, the Court appeared to go out of its way to suggest in dictum that "maintenance of a revered tradition of amateurism in college sports" could justify a nationwide agreement of colleges not to reward "student-athletes" in accordance with their market value. See id. at 2971. For other cases suggesting continued judicial acceptance of a "worthy purpose" defense where professionals are involved, see infra notes $95 \& 101$.

73. A limited and principled exception to the rule that worthy purposes cannot justify a restraint might be made in cases where the theory underlying the policy of promoting competition is invalidated by the presence of a demonstrable market failure and where the restraint in question could reasonably be expected to make actual market outcomes resemble more closely the outcomes in an efficient market. See P. AREEDA, ThE "Rule of REASON" IN ANTITRUST ANALYSIS: GENERAL IsSUES 5-8 (Federal Judicial Center 1981); Havighurst \& King, supra note 57, at 297-98 n.108. Because many markets for professional services are characterized by consumer ignorance, some restraints might conceivably be defensible under such a theory. For example, medical associations might be permitted to control deceptive advertising on the theory that consumers can rely on advertising only if there is some assurance that it is truthful. See id. at 276-80. It would be a mistake, however, to recognize a self-regulatory role for professional groups simply because a significant mar- 
case, as here, that activities deemed to be procompetitive are desirable in other respects as well. ${ }^{74}$

The requirement that a hospital medical staff must be able to justify its anticompetitive activities by reference to the hospital's purposes has an important corollary-namely that the staff may not rely upon purposes of its own to justify an anticompetitive action. Thus, there is no warrant in standard antitrust doctrine for a medical staff's acting as a unit for collective bargaining with the hospital. Although there would be no objection to the staff's collective advocacy of policies that the hospital board might adopt, the line of illegality is crossed when physicians take concerted action against the hospital-such as by collectively threatening to take their patients elsewhere if their wishes are not granted. There is little doubt that independent physicians are not free-as employees organized into a labor union are free-to make collective decisions about whether, when, where, or on what terms to supply their services. ${ }^{75}$ Of course, it is often difficult to distinguish between a threat to take collective action and a mere prediction that individuals will act in a certain way in certain circumstances, ${ }^{76}$ but the law is reasonably clear in prohibiting naked group boycotts and refusals to deal. ${ }^{77}$ Although many medical staffs probably violate this basic rule from time to time in their dealings with hospitals, few are likely to be caught. ${ }^{78}$ Physicians should

ket failure exists and could theoretically be rectified. Although self-regulation might in theory be capable of bringing about market outcomes more in keeping with the free-market paradigm than the results a faulty market could achieve, it could reasonably be expected to do so only in the unlikely absence of any conflict of interests on the part of the self-regulators. See id.

74. Ultimately, of course, desirability is a matter not for courts to determine but for consumers to judge in the marketplace. See infra note 189.

75. See, e.g., In re Michigan State Medical Soc'y, 101 F.T.C. 191, 289-96 (1983) (holding medjcal society's boycott affecting reimbursements per se illegal). But $c f$. Indiana Fed'n of Dentists v. FTC, 745 F.2d 1124, 1137-38 (7th Cir. 1984) (dental association allowed to "require that group dental health care insurers do business on the dentists' terms, in compliance with establislied, accepted, and approved standards of quality dental care."). Although $\S 6$ of the Clayton Act, 15 U.S.C. $\$ 17$ (1982), states that human labor is not a commodity or article of commerce, this antitrust exemption has been construed narrowly to cover only employees, who are entitled to organizc labor unions, and not independent sellers of services. See United States v. National Ass'n of Real Estate Bds., 339 U.S. 485, $489-90$ (1950); Atlantic Cleaners \& Dyers, Inc. v. United States, 286 U.S، 427, 435-36 (1932).

76. For a discussion of the problems encountered in proving a physician boycott, see Havighurst, supra note 49 , at $345-49$.

77. See infra notes 100-14 and accompanying text. Without the hospital's backing, the staff's actions lose their claim to be analyzed as ancillary rather than naked restraints.

78. However, five doctors in a small Texas town were sued successfully by the Federal Trade Commission for attempting to prevent a hospital from offering employment to a board-certified obstetrician-gynecologist. Sherman A. Hope, M.D., [1979-83 Transfer Binder] TRADE REg. REP. (CCH) I 21,791 (Feb. 19, 1981) (consent order); see also Weiss v. York Hosp., 745 F.2d 786, 818-20 (3d Cir. 1984) (boycott found implicit in M.D.s' "control over York's admission decisions" though no evidence of actual coercion of the hospital appeared); Maryland v. Medical Staff, No. 36/544/ 
nevertheless be advised that their financial liability could be substantial if they should carry out any threat to harm the hospital, or if a plaintiff could prove that he lost business or employment as a result of their collective pressure on institutional decisionmakers.

Perhaps the most important implication of the antitrust rules under which medical staff actions are tested by reference to the hospital's business purposes is that the staff is a subsidiary and not an independent element within the hospital and is subject in the last analysis to the authority of the governing board. ${ }^{79}$ This view is essentially consistent with basic concepts of corporation law $w^{80}$ and also with the conception of the hospital/staff relationship that is set forth in JCAH standards. ${ }^{81}$ Although the medical staff's formal subordination to the hospital board is seldom doubted, rigorous insistence on some of the implications of this hierarchical structure may be quite controversial. It is argued below, ${ }^{82}$ for example, that an antitrust court, when asked to review a hospital decision on staffing or admitting privileges, should inquire specifically whether the hospital board in fact maintained its independence or instead abdicated its formal responsibilities in favor of the medical staff.

27734 (Md. Cir. Ct., Oct. 29, 1981), summarized in ANTITRUst \& TRADE REg. REP. (BNA) No. 1038, at D-4 (Nov. 5, 1981) (medical staff disagreed with hospital's decision to contract with radiologists on a salary rather than fee-for-service basis and threatened to boycott the new radiologists; in a settlement, staff agreed not to engage in boycott).

79. Some courts have held that the staff's subservient position in the hospital enterprise is such that no antitrust conspiracy can be found between the hospital and the staff. See infra note 179.

80. General principles of corporate law place ultimate responsibility for the management and operation of the hospital upon the governing board. The board must exercise reasonable care in operating the hospital, an obligation that includes the duty to provide satisfactory patient care. See supra text accompanying notes 20-24; see also W. ISELE, supra note 8, at 61; R. MiLIER, supra note 8 , at 25-32.

81. Prior to recent revisions, JCAH standards held that the hospital's governing body "has overall responsibility for the conduct of the hospital in a manner consonant with the hospital's objective of making available high-quality patient care" and that the medical staff was responsible for "the quality of all medical care provided to patients, and for the ethical conduct and professional practices of its members, as well as for accounting therefor to the governing body." 1983 MANUAL, supra note 47 , at 51, 93. While preserving the board's de jure authority, these standards went very far toward making that authority purely formal. See infra note 155 . Recent revisions require that the governing body must be "responsible for establishing policy, maintaining quality patient care, and providing institutional management and planning," 1984 MANUAL, supra note 8, at 49, but assign to the medical staff "overall responsibility for the quality of the professional services . . . as well as the responsibility of accounting therefor to the governing body," Revised Medical Staff Standards, supra note 47 , at 1 . Although these standards recognize the board's formal authority, they carry implications that may be seen to clash with the conclusions drawn from the antitrust analysis in this article.

82. See infra text accompanying notes $139-73$. 


\section{STATUTORY AND COMMON LAW GOVERNING HOSPITAL Admitting Privileges-The Need for a NeW RATIONALE}

It is widely remarked that the law governing the award of hospital admitting privileges forces hospitals to steer a treacherous course. On the one hand, the Scylla of tort law imposes on hospitals a duty to exercise due care in deciding which providers may use their facilities. ${ }^{83}$ On the other hand, a Charybdis of common-law doctrines, statutory rules, and antitrust principles threatens a hospital with substantial burdens and penalties if it should act unfairly or illegally in denying, revoking, or curtailing an individual provider's privileges. Although this article concentrates on antitrust issues, its emphasis on the dynamic features of hospital/physician relationships, the allocation of decisionmaking responsibilities, and the overriding interest of consumers should make it helpful to courts that are asked to review denials of staff privileges under common-law principles. Essentially the same arguments that are advanced herein against extensive judge-made protection for physicians in their dealings with hospitals may be addressed to state legislatures and regulatory bodies that impose comparable restrictions on hospital discretion. ${ }^{84}$

Common-law courts in a number of jurisdictions have conferred substantial legal protections upon applicants for hospital admitting privileges, mostly by their readiness to review hospital actions under norms of substantive and procedural due process. ${ }^{85}$ Although well established,

83. See supra notes $\mathbf{2 0 - 2 6}$ and accompanying text.

84. Some statutes and hospital licensing regulations require that some form of procedural due process be accorded to individual practitioners seeking admitting privileges. E.g., FLA. STAT. ANN. $\S 395.011(5)$ (West Supp. 1984) (hospital must state reasons for denying privileges); NEW YORK Pub. Health Law § 2801-6(1) (McKinney 1977) (similar); Ill. Op. Att'y Gen. No. 84-004 (Apr. 4, 1984) (available Dec. 31, 1984, on LEXIS, States library, Illag file) (podiatrists applying for staff membership must be afforded procedural due process and fair hearing on application). These requirements are similar in nature and effect to the common-law rules criticized in the text.

85. The leading case is Greisman v. Newcomb Hosp., 40 N.J. 389, 397.404, 192 A.2d 817, 82125 (1963) (private nonprofit hospital possessing "virtual monopoly" held bound by common-law public utility obligations). See also Storrs v. Lutheran Hosp. \& Homes Soc'y, Inc., 609 P.2d 24, 28 (Alaska 1980); Peterson v. Tucson Gen. Hosp., 114 Ari. 66, 71, 559 P.2d 186, 191 (1976); Ascherman v. San Francisco Medical Soc'y, 39 Cal. App. 3d 623, 631, 114 Cal. Rptr. 681, 685 (1974); Silver v. Castle Memorial Hosp., 53 Hawaii 475, 483-85, 497 P.2d 564, 571, cert. denied, 409 U.S. 1048 (1972); Bricker v. Sceva Speare Memorial Hosp., 111 N.H. 276, 280-81, 281 A.2d 589, 592, cert. denied, 404 U.S. 995 (1971); Davidson v. Youngstown Hosp. Ass'n, 19 Ohio App. 2d 246, 250, 250 N.E.2d 892, 896 (1969). Cases rejecting the notion that private hospitals have any special duty to justify their actions include Shulman v. Washington Hosp. Center, 222 F. Supp. 59, 63-64 (D.D.C. 1963) (citing authorities for what was, until Greisman, a unanimous refusal to review the privileges decisions of private hospitals); Knapp v. Palos Community Hosp., 125 Ill. App. 3d 244, 465 N.E.2d 554, 563 (1984); Jain v. Northwest Community Hosp., 67 Ill. App. 3d 420, 426-27, 385 N.E.2d 108, 113 (1978); Hoffman v. Garden City Hospital-Osteopathic, 115 Mich. App. 773, 779, 
these fairness requirements, which are applicable in some degree to private as well as public hospitals, ${ }^{86}$ appear to need rethinking in the light of recent developments in national health policy and the evolution of the health care industry toward organization and operation along more competitive lines. When active enforcement of the antitrust laws against health care providers began in the late 1970 's, ${ }^{87}$ there occurred, almost ipso facto, a redefinition of national policy toward the health care sector. In effect, the antitrust initiative reversed a federal policy of tacitly accepting the prevalent view among health care providers that they were justified in insulating themselves from competitive pressures. Whereas doubts about the value and appropriateness of competition in health care had previously weakened the resolve of courts and enforcement agencies to insist upon competition and left policy in a kind of limbo, federal policy today is rather clear. It starts from the proposition that the health care sector is a competitive industry to be guided, for better or worse, by market forces unless Congress expressly declares otherwise or regulatory controls have clearly been substituted. ${ }^{88}$

The common-law courts that came to oversee hospitals' denials of privileges did so in an environment substantially different from the current one. Moreover, they expressly found their authority in a conception of the private hospital as a quasi-public enterprise or public utility rather than as a private business operating in an essentially competitive environment. ${ }^{89}$ It is far from clear today why hospitals are under any greater

321 N.W.2d 810, 813 (1982); Ponca City Hosp. v. Murphree, 545 P.2d 738, 740-42 (Okla. 1976). See generally Note, Judicial Intervention in Admissions Decisions of Private Professional Associations, 49 U. CHI. L. REv. 840, 857-58 (1982) (criticizing trend toward making private groups accountable); Note, Exclusion from Private Associations, 74 YALE L.J. 1313, 1321-23 (1965) (advocating judicial involvement).

86. See supra note 85 . One line of authority went quite far in treating actions of private hospitals as "state action" in order to make constitutional norms applicable. This approach is less promising today in light of Jackson v. Metropolitan Edison Corp., 419 U.S. 345, 351 (1974) (requiring state nexus). See Modaber v. Culpeper Memorial Hosp., 674 F.2d 1023, 1025 (4th Cir. 1982) (action is "state action" only if it is one taken exclusively by the state, for the state's direct benefit, or at the state's specific behest); Schlein v. Milford Hosp., Inc., 561 F.2d 427, 428 (2d Cir. 1977) (nexus must be such that private entity may fairly be treated as state actor).

87. The federal antitrust laws were finally held to apply to the so-called "learned professions" in Goldfarb v. Virginia State Bar, 421 U.S. 773, 793 (1975). That decision stimulated significant antitrust activity in the health care field. See, e.g., Havighurst, The Contributions of Antitrust Law to a Procompetitive Health Policy, in Market Reforms in Health CARe 295, 300 (J. Meyer ed. 1983); Symposium, The Antitrust Laws and the Health Services Industry, 1978 DuKe L.J. 301.

88. On the construction of the antitrust laws in light of federal health legislation, see National Gerimedical Hosp. \& Gerontology Center v. Blue Cross, 452 U.S. 378, 393 (1981); North Carolina ex rel. Edmisten v. P.I.A. Asheville, 740 F.2d 274, 280-82 (4th Cir. 1984) (en banc); Hospital Building Co. v. Trustees of Rex Hosp., 691 F.2d 678 (4th Cir. 1982), cert. denied, 104 S. Ct. 231 \& 259 (1983); C. HAVIGHURST, supra note 1, at 159-79; Havighurst, Health Planning and Antitrust Law: The Implied Amendment Doctrine of the Rex Hospital Case, 14 N.C. CENT. L.J. 45 (1983).

89. E.g., Gresiman v. Newcomb Hosp., 40 N.J. 389, 395-98, 192 A.2d 817, 820-22 (1963). 
obligation than typical employers to account to the courts for the fairness with which they screen applicants for professional positions or why health care professionals deserve any special legal help in surmounting marketplace barriers to their pursuit of a livelihood. ${ }^{90}$ The due process requirements that common-law courts have required private hospitals to observe in allocating staff privileges are in fact anomalous and find weak support in the common-law ground in which they are rooted.91

A reexamination of the staff privileges issue in light of the new economic environment and more market-oriented national policies toward the health care sector would suggest that common-law courts, instead of applying to hospitals norms drawn from constitutional or public utility law, should ground their review of privileges decisions in tort principles applicable to unfair competition. ${ }^{92}$ This approach would call appropriate attention to the frequently controlling influence of physician-competitors of an applicant for privileges. Adoption of the unfair competition rationale would also, like the antitrust analysis below, ensure that any decision made by and in the interest of the hospital itself and not by the medical staff alone would be permitted to stand unless contrary to statutory law. Moreover, judicial review of medical staff activities under such a tort rationale would not simply duplicate antitrust remedies. Not only would a tort action not require proof of an effect on interstate commerce, ${ }^{93}$ but it also would focus substantially more upon issues of fairness than would an antitrust court, which should be primarily concerned with the protec-

90. It must be noted that the employment-at-will doctrine has come under increasing attack during the last decade, suggesting that all employees may someday possess legal protection against arbitrary or unfair dismissal. See genterally Individual Rights in the Workplace: The Employment-atwill Issue, 16 U. MICH. J. L. REF. 199 (1983); Gold \& Hamilton, Employer Liability Grows for Discharging At-will Employees, HosPS., July 16, 1984, at 121, 123-24. The efficiency-oriented arguments in this article against legal recognition of noncontractual vested rights in staff privileges might also be applied to this trend in employment law. See, e.g., Epstein, In Defense of the Contract at Will, 51 U. CHI. L. REv. 947 (1974). Of course, one might argue either that licensed professionals have a stronger claim to job security than persons in other occupations or that quality-of-eare concerns make hospitals' need for wide discretion in dealing with professionals greater than that of employers of other kinds.

91. Such uses of ancient [public utility] doctrines to extend judicial oversight to new institutions is [sic] questionable on the ground that modern legislatures have long since taken over the regulatory powers formerly exercised by common-law courts and can now be presumed to define the proper extent of state intervention in private affairs. . . . Although many state legislatures have in fact regulated the health care industry, particularly hospitais, along public utility lines, it would seem that the legal obligations of organizations enfranchised by such regulation should be found in the regulatory legislation itself, not judicial extensions of it.

Havighurst \& King, supra note 57, at 160 (footnote omitted). For discussions of public-utility-type regulation of hospitals through entry regulation by "certificate of need," see Havighurst, supra note 1, at 53-76; Certificate-of-Need Laws in Health Planning, 1978 UTAH L. REv. 1.

92. See Havighurst \& King, supra note 57 , at $160-64$.

93. See infra notes $233-37$ and accompanying text. 
tion of "competition, not competitors."94 Despite the somewhat different -emphasis of antitrust law, the antitrust discussion herein should significantly assist common-law courts in dealing with the legal questions and the complicated and hotly disputed factual situations that they confront in privileges cases.

\section{A Refutation of Two Common Antitrust Fallacies Concerning Hospital Privileges}

Attempts to apply antitrust law to denials of hospital admitting privileges have failed to clear up some serious doctrinal confusion. Indeed, some of this confusion appears to have achieved the status of conventional wisdom and thus to be part of what passes for law in this emerging area. Nevertheless, clarification of two of these matters must be achieved before antitrust law can benefit consumers. The following paragraphs, although not fully investigating all of the sources of confusion, are an attempt to clear away some doctrinal underbrush so that the legal forest can be made a safe environment in which hospitals can carry out their mission. Fortunately, the legal fallacies challenged below have not been instrumental in deciding privileges cases and should therefore be open for judicial reexamination.

\section{A. The Fallacy That the Administration of Privileges Constitutes "Professional Self-Regulation."}

Some observers believe, on the basis of dicta in Supreme Court opinions and other signs, that professionals might still be allowed to regulate themselves and their economic environment in anticompetitive ways-a privilege not permitted to other varieties of tradesmen. ${ }^{95}$ This possibility

94. Brunswick Corp. v. Pueblo Bowl-O-Mat, Inc., 429 U.S. 477, 488 (1977) (quoting Brown Shoe Co. v. United States, 370 U.S. 294, 320 (1962)). See infra note 113 and accompanying text.

95. See generally supra note 87. In each recent case in which the Supreme Court has found professionals guilty of antitrust violations, the Court has indicated that professionals might receive special treatment under other circumstances. See Arizona v. Maricopa County Medical Soc'y, 457 U.S. 332, 348-49 (1982); National Soc'y of Prof. Eng'rs v. United States, 435 U.S. 679, 696 (1978); Goldfarb v. Virginia State Bar, 421 U.S. 773, 788 n.17 (1975). For other dicta to the same effect, see Bates v. State Bar of Arizona, 433 U.S. 350, 368-70 (1977); United States v. Oregon State Medical Soc'y, 343 U.S. 326, 336 (1952). The most explicit judicial recognition of special physician prerogatives appears in Wilk v. AMA, 719 F.2d 207 (7th Cir. 1983), cert. denied, 104 S. Ct. 2388 \& 2399 (1984), discussed infra note 101. Other expressions of the need for special treatment of physicians include Indiana Fed'n of Dentists v. FTC, 745 F.2d 1124 (7th Cir. 1984); Hospital Bldg. Co. v. Trustees of Rex Hosp., 691 F.2d 678, 686 (4th Cir. 1982), cert. denied, 104 U.S. 231 \& 259 (1983); Arizona v. Maricopa County Medical Soc'y, 643 F.2d 553, 556 (9th Cir. 1980), rev'd, 457 U.S. 332 (1982); Norris \& Szabo, Communication Between the Antitrust and the Health Law Bars: Appeals for More Effective Dialogue and a New Rule of Reason, 7 AM. J. L. \& MED. i, i (1981); Pfizenmayer, Antitrust Law and Collective Physician Negotiations with Third Parties: The Relative Value Guide Object Lesson, 7 J. Health Pol., PoL'y \& L. 128, 147 (1982). 
is uniformly recited whenever the antitrust issues raised by denials of staff privileges are discussed, and its relevance to the establishment of standards for judicial review of such actions is generally assumed. ${ }^{96}$ But, whether or not the Supreme Court might grant some special prerogatives to professionals in some future case, ${ }^{97}$ one can analyze staff privileges problems satisfactorily without regard to the legal treatment accorded to professional self-regulation. Indeed, as the following discussion indicates, it would be inappropriate for antitrust courts to treat the administration of staff privileges specially even if they were prepared to leave room for professionals to regulate themselves in certain circumstances.

To begin with, the administration of staff privileges does not involve "self-regulation" in the strict sense. Concerted actions of competitors that are truly regulatory-in the sense that they directly control marketwide behavior-are precisely the type of conduct that raises the most serious antitrust concerns. Naked agreements to suppress price

96. See, e.g., Kissam \& Webber, supra note 13, at 614-19; Dolan \& Ralston, supra note 19, at 735-39; Drexel, supra note 19, at 227-30. Judicial analysis, too, usually proceeds from a recognition that professionals may not be subject to the same rules as ordinary businessmen. See, e.g., Smith v. Northern Mich. Hosps., Inc., 703 F.2d 942, 949 n.12 (6th Cir. 1983); Vuciecevic v. MacNeal Memorial Hosp., 572 F. Supp. 1424, 1427-28 (N.D. Ill. 1983); Pontius v. Children's Hosp., 552 F. Supp. 1352, 1363-65, 1368-70 (W.D. Pa. 1982); Robinson v. Magovern, 521 F. Supp. 842, 905-06 (W.D. Pa. 1981). In Weiss v. York Hosp., 745 F.2d 786, 820-22 (3d Cir. 1984), the court characterized the administration of staff privileges as "industry self-regulation" requiring a balancing approach but applied a per se rule where the staff was found to be discriminating against osteopaths. The court's confusion of legitimate collective action in a single hospital with dangerous industry self-regulation appeared to flow from its reliance on Professor Sullivan's treatise. See id. at 820 n.59 (citing L. Sullivan, ANTITRUST $\S \S 86-88$ (1977)).

97. Each of the successive statements by the Supreme Court cited supra note 95 significantly narrowed the previously stated grounds for possible departures from standard principles, arguably to the point where there is nothing left. Indeed, the Court may now have concluded that the special problems encountered in applying the antitrust laws to the health care industry can be accommodated by intelligent application of existing doctrine and do not require any bending of the usual rules. In National Soc'y of Prof. Eng'rs v. United States, 435 U.S. 679, 696 (1978), the Court observed that "professional services may differ significantly from other business services, and, accordingly, the nature of the competition in such services may vary." The crucial point about this observation is that, instead of suggesting a need for exemptions, it retains the exclusive focus of antitrust law on competition and simply underscores the need for alertness to the unusual features of competition in markets where such complicating factors as third-party payment and consumer ignorance are prevalent. Interestingly, the Court's statement can be read as counselling not a tolerant approach, but special vigilance against the possibility that new types of anticompetitive abuse will be encountered in markets of this unusual kind. Other Supreme Court dicta regarding the dangers of "deception," the need for ethical norms, and the public service features of the professions could, without much difficulty, be reconciled with traditional antitrust principles by adopting a limited market-failure defense for competitor collaboration along the lines suggested supra note 73. In short, there is no justification, or need, for a relaxation of the requirement of competition in markets for professional services. For criticism of the deviation from sound principle in Wilk v. AMA, 719 F.2d 207 (7th Cir. 1983), cert. denied, 104 S. Ct. 2398 \& 2399 (1984) and in Indiana Fed'n of Dentists v. FTC, 745 F.2d 1124 (7th Cir. 1984), see infra note 101. See generally Havighurst \& King, supra note 57 , at $296-300$. 
competition or coerce third parties are sharply distinguishable, however, from concerted action to accomplish some procompetitive purpose, which should be analyzed sympathetically under the rule of reason. As earlier discussion has made clear, ${ }^{98}$ the actions of a hospital medical staff taken on behalf of the hospital fall into this second category of restraints. Because traditional antitrust principles leave ample room for hospital medical staffs to act on technical matters within the hospital, there is no need to invoke the possibility that professionals may enjoy special prerogatives to regulate the markets in which they compete. Such deference as courts have accorded hospital medical staffs appears to flow from their key role in operating their respective hospitals as competitive enterprises and not from the professional status of their members. 99

Although physicians on a medical staff might raise professionalism as a defense for collective action taken by them in opposition to the interests of the hospital, that defense should fail. ${ }^{100}$ The doctors might claim that, because their objectives were purely professional and undertaken in the interest of their patients, they were justified in acting beyond the scope of their mandate from the hospital. Although one recent court of appeals decision ${ }^{101}$ has suggested that a naked physician boycott of chi-

98. See supra text accompanying notes $62-82$.

99. Although courts frequently start by acknowledging that professionalism may carry certain prerogatives, see supra note 96 , they normally rest their decisions favorable to hospitals and medical staffs on the fact that business purposes of the hospital were furthered. See, e.g., Smith v. Northern Mich. Hosps., Inc., 703 F.2d 942, 952 (6th Cir. 1983) (challenged practices held "the product of NMH's singular efforts to provide appropriate medical care"); Robinson v. Magovern, 521 F. Supp. 842, 859-63, 917-19, 921 (W.D. Pa. 1982) (defendants' criteria in evaluating application for staff privileges found an integral part of hospital's successful revitalization plan); Williams v. Kleaveland, 534 F. Supp. 912, 920 (W.D. Mich. 1981) (to prove a $\$ 1$ violation, plaintiff physician must show that the defendant doctors acted "to benefit their private practices rather than to maintain the legitimate standards of the hospital"). Another way in which courts have manifested their acceptance of the hospital's business purposes is to hold that the hospital and the medical staff constitute a single entity and cannot conspire with each other. See infra note 179.

100. See supra text accompanying notes 74-78.

101. Wilk v. AMA, 719 F.2d 207, 226 (7th Cir. 1983), cert. denied, 104 S. Ct. 2398 \& 2399 (1984). The court reversed a verdict in favor of several medical organizations in a boycott case brought by chiropractors. However, instead of applying the usual per se rule against boycotts targeted at competitors, see infra notes 104-14 and accompanying text, the court indicated that the defendants should be allowed to introduce evidence that their motive for the boycott was not economic but a desire to protect their patients against an "unscientific cult." Wilk, 719 F.2d at 213. Thus, the court invited the jury to distinguish between a boycott for a "public-interest motive," which would be an unlawful attempt to reverse by private action the legislature's recognition of chiropractic through licensure, and a boycott expressing a "patient-care motive," embodying the medical profession's commitment to science. Id. at 228. Not only is this distinction exceedingly fine, but it is hard to agree that it should save the boycott in Wilk, which, among other things, denied to the patients of chiropractors the benefits of the very scientific medicine that the physicians touted so highly. The court's attenuation of the normal requirement of decentralized decisionmaking by individual competing units violates the most fundamental of antitrust principles. See infra notes 107-09 and accompanying text and note 115 . For an early dictum indicating an even more lenient attitude 
ropractors might be justified if undertaken for "patient-care motives" and in defense of scientific values, that result is highly debatable. Moreover, its only possible rationale-the arguable need of consumers for protection against the consequences of their ignorance in purchasing health services-is inapplicable to concerted action that displaces the hospital as an independent decisionmaker. Because a hospital can obtain professional assistance in making technical decisions and must satisfy patients in a competitive environment, it can be viewed as a sophisticated and accountable agent of the ignorant consumer in making personnel decisions. The medical staff, on the other hand, has a potential conflict of interests that makes it a less reliable advocate for consumer interests on such questions. Thus, physicians' collective infringements on hospitals' decisionmaking freedom cannot be defended as a response to a market failure. ${ }^{102}$ Staff privileges issues are therefore appropriately considered without regard to any separate professionalism defense.

\section{B. The Fallacy That a Denial of Privileges Constitutes a "Group Boycott" or "Concerted Refusal to Deal."}

The confusion in the use of the terms "group boycott" and "concerted refusal to deal" in antitrust analysis may by now be so great that it is futile to argue that words should be given their natural and sensible meaning. ${ }^{103}$ Nevertheless, until the Supreme Court departs from its consistent clarity on the point and ratifies the prevalent misuse of these concepts, it seems helpful to insist that the terms "group boycott" and "concerted refusal to deal" refer only to naked horizontal agreements by which competing buyers or sellers adopt a common policy toward one or

toward physician boycotts, see United States v. Oregon St. Medical Soc'y, 343 U.S. 326, 336 (1952), criticized in Havighurst, supra note 49, at 313-15, 347-53. For a more recent case allowing professionals to deviate from the requirement of independent decisionmaking, see Indiana Fed'n of Dentists v. FTC, 745 F.2d 1124 (7th Cir. 1984) (dentists' agreement not to compete in making $x$-rays available to dental insurers held permissible in absence of affirmative proof that competition would serve consumers).

102. See supra note 73 .

103. Although some have attempted to differentiate between them on some basis, the two terms are probably interchangeable. See, e.g., Klor's, Inc. v. Broadway-Hale Stores, 359 U.S. 207, 212 (1959) ("[g]roup boycotts, or concerted refusals by traders to deal with other traders, have long been held to be within the forbidden category"; the modifier "group" is probably redundant, concerted action being implicit). The terms are not mere conclusory labels but instead are meaningful and useful in giving effect to important antitrust policies. Thus, some mischief has been done by efforts to expand their scope to encompass vaguely analogous conduct and by such statements as Professor Areeda's that "boycotts are not a unitary phenomenon." P. AREEDA, ANTITRUST ANALYSIS 381 (2d ed. 1974), quoted in St. Paul Fire \& Marine Ins. Co. v. Barry, 438 U.S. 531,543 (1978). Despite the Supreme Court's statement that its "decisions reflect a marked lack of uniformity in defining the term," 438 U.S. at 543, a true boycott, as defined in the text, is readily recognizable and subject to relatively straightforward legal analysis. See infra note 109. 
more suppliers or customers. ${ }^{104}$ It is notable that this definition, unlike the vague ones in common use, ${ }^{105}$ does not encompass a refusal to deal by a single entity. Even if the single entity is under the control of a combination of competitors-as a hospital denying admitting privileges might be under the influence of its medical staff-,it is incapable of perpetrating a true boycott or concerted refusal to deal. Its actions are thus distinguishable from, say, an agreement among individual members of a medical staff to take their patients to another hospital or to withhold referrals to, or refuse referrals from, a particular practitioner. ${ }^{106}$

Maintenance of a sharp distinction between multiple and individual refusals to deal is important from a policy standpoint. The essential vice of naked agreements among competitors is their abrogation of the independent decisionmaking that is the norm in competitive markets. ${ }^{107}$

104. See St. Paul Fire \& Marine Ins. Co. v. Barry, 438 U.S. 531, $541-44$ (1978) (reviewing use of the term "boycott" in Sherman Act cases and applying it to an agreement among competitors not to sell a specific product). No Supreme Court opinion has ever employed either term-even, it appears, in passing-to describe a refusal to deal by a single competitor-controlled entity. On the now common misreading of Radiant Burners, Inc. v. Peoples Gas Light \& Coke Co., 364 U.S. 656, 659-60 (1961) (per curiam), as so characterizing a denial of a seal of approval for an industrial product, see Havighurst \& King, supra note 57, at 174-75. A pending case will give the Supreme Court a new opportunity to clarify terminology. See Northwest Wholesale Stationers, Inc. v. Pacific Stationery \& Printing Co., 715 F.2d 1393, 1395 (9th Cir.) (calling termination of membership in purchasing cooperative a "boycott"), cert. granted, 105 S. Ct. 77 (1984).

105. Cases using the term "boycott" to describe the action of a single competitor-controlled entity include Pacific Stationery \& Printing Co. v. Northwest Wholes. Stationers, Inc., 715 F.2d 1393, 1395 (9th Cir.), cert. granted, 105 S. Ct. 77 (1984); Virginia Academy of Clinical Psychologists v. Blue Shield, 624 F.2d 476, 484 (4th Cir. 1980), cert. denied, 450 U.S. 916 (1981) (discussed infra notes 272-73 and accompanying text); Robinson v. Magovern, 521 F. Supp. 842, 906 (W.D. Pa. 1981). Commentators whose definitions or conclusions override the distinction between naked boycotts and refusals to deal by a procompetitive joint venture include E. GELLHORN, ANTITRUST LAW AND ECONOMICS 190-204 (2d ed. 1981) (defining "boycott" as any refusal to deal affecting competitors that results from competitor collaboration); L. Sullivan, ANTITRUST $\S 83$ (1977) (treating boycotts and refusals to deal as similar, though not identical, actions and downplaying the distinction); Bauer, Per Se Illegality of Concerted Refusals to Deal: A Rule Ripe for Re-examination, 79 Colum. L. REv. 685 (1979) (obfuscating relevant distinctions); Kissam, Antitrust Boycott Doctrine, 69 IowA L. REV. 1165, 1167 (1984) (broadly defining "boycott," in terms of its impact, to mean "any concerted effort of economic actors that excludes other parties from a market or market resource by a refusal to deal with these parties or third parties who would do business with them"); Ponsoldt, The Application of Sherman Act Antiboycott Law to Industry Self-Regulation: An Analysis Integrating Nonboycott Sherman Act Principles, 55 S. CAL. L. REV. 1, 9-15 (1981) (making appropriate distinctions but not insisting on appropriate terminology); see also BUREAU OF CONSUMER PROTECTION, FTC, STANDARDS AND CerTification 247-49 (1983) (treating standard-setting and certification programs as restraints of trade "similar to some group boycotts in that the effect of a standard is to infiuence purchasers not to deal with producers whose products do not comply").

106. See supra notes $75-78$ and accompanying text.

107. In Klor's, Inc. v. Broadway-Hale Stores, 359 U.S. 207, 209-10 (1959), the plaintiff alleged that its competitor had organized a boycott among its suppliers. The Supreme Court criticized group boycotts by observing that they " "cripple the freedom of traders and thereby restrain their ability to sell in accordance with their own judgment." "Id. at 212 (quoting Kiefer-Stewart Co. v. Joseph E. Seagram \& Sons, 340 U.S. 211, 213 (1951)). Though it is easy to misread these statements, 
True boycotts thus are appropriately treated as per se violations-unless they are political or noncommercial in nature and therefore fall outside of the economic sphere that the Sherman Act was intended to police. ${ }^{108}$ Because commercial boycotts nakedly impair competitive, decentralized decisionmaking, courts have little reason to investigate their actual purpose or effect on competition before condemning them. ${ }^{109}$ On the other

the traders whose freedom is to be maintained are the boycotters themselves, not their targets. Thus, in Klor's, the Court also observed that the boycott "deprives the manufacturers and distributors of their freedom to sell to Klor's . . . " 359 U.S. at 213. Although the Supreme Court began its analysis in St. Paul Fire \& Marine Ins. Co. v. Barry, 438 U.S. 531 (1978), by observing that the "generic concept of boycott refers to a method of pressuring a party with whom one has a dispute," 438 U.S. at 541 , it went on to apply the term to a naked anticompetitive agreement the object of which was not to pressure anyone. It is of course natural for courts in boycott cases to observe the harm and unfairness to the victim, see infra note 112 , but the harm to competition lies elsewhere-in the naked surrender of the collaborators' independence.

108. See, e.g., Missouri v. National Org. for Women, 620 F.2d 1301, 1315 (8th Cir.), cert. denied, 449 U.S. 842 (1980) (Sherman Act inapplicable to boycott to achieve political objective); Raup, Medicaid Boycotts by Health Care Providers: $A$ Noerr-Pennington Defense, 69 IowA L. REV. 1393 (1984) (arguing that boycotts aimed at increasing reimbursement rates set monopsonistically by government agencies are not covered by the Sherman Act under a doctrine that exempts attempts to influence government action); $c f$. NAACP v. Claiborne Hardware, 458 U.S. 886, 913-14 (1982) (observing the Noerr-Pennington doctrine's application to a consumer boycott for social, economic, and political goals). Boycotts for a social objectives may also be deemed to be outside the ambit of the Sherman Act, which may be appropriately construed to protect against actions that prevent the free market from resolving issues that are primarily economic in nature. See generally Bird, Sherman Act Limitations on Noncommercial Concerted Refusals to Deal, 1970 DukE L.J. 247, 288-92; Coons, Non-commercial Purpose as a Sherman Act Defense, 56 Nw. U.L. REV. 705, 754-55 (1962). A broader noncommercial-purpose defense is sometimes advocated, but, if this means letting parties with a commercial interest in the outcome plead pure motives, it would go too far. See supra notes 100-02 and accompanying text; Havighurst, supra note 49, at 349-60, especially nn.214 \& 225 .

109. A true commercial boycott is or should be subject to fairly straightforward legal analysis. The per se rule is appropriately applied because naked collective decisions not to deal represent a clear departure from the fundamental antitrust premise that independent competitive entities ought to act independently, and that collaborative decisionmaking by parties with an economic interest in the outcome poses a threat to consumer interests. See infra note 115 . In order to preserve somc flexibility in the law-if only so that the law will not seem mindless in its insistence on competition-, the per se rule may appropriately be relaxed to allow in rare cases the market-failure defense outlined supra note 73 or the narrow noncommercial-purpose defense noted supra note 108 and accompanying text. Also, an agreement not to deal should escape condemnation if it can be justified as an ancillary restraint furthering the purposes of a legitimate joint venture, see supra note 63 , such as a sports league. See, e.g., Molinas v. National Basketball Ass'n, 190 F. Supp. 241, 243 (S.D.N.Y. 1961) (disciplinary suspension of player, for gambling, in order to preserve quality of league contests and league integrity).

Despite the obvious anticompetitive character of naked agreements to boycott, courts and commentators frequently suggest that, before it can be condemned, a boycott must be aimed at destroying a competitor or have some other anticompetitive purpose. See, e.g. St. Paul Fire \& Marine Ins. Co. v. Barry, 438 U.S. 531, 541 \& n.14, 542 (1978). Wilk v. AMA, 719 F.2d 207 (7th Cir. 1983), cert. denied, 104 S. Ct. 2398 \& 2399 (1984) (criticized supra note 101), is an extreme example of a case insisting on an impure motive. The following references, typical of many that make a point of asking whether the boycott in question had or was intended to have adverse effects on competition, show how widespread is the failure to recognize the restraint inherent in the agreement to boycott itself, see supra note 107, and how desirable would be a reiteration by the Supreme Court that- 
hand, a refusal to deal by a lawfully constituted competitor-controlled entity can be found illegal only if it has an actual and impermissible adverse effect on competition. Such an effect might be detectable in the handicap created by a refusal of membership or some seal of approval to third parties seeking to compete with the entity's sponsors. Nevertheless, as later discussion will show, ${ }^{110}$ the particular actions of legitimate joint ventures, such as a hospital medical staff, should be spared close legal scrutiny once the court is satisfied that the venture has been arranged and operated so as to accomplish its procompetitive purposes without unreasonable risk of anticompetitive abuse.

Recognition of the distinction between a true boycott and a refusal to deal by a single entity would also be helpful in avoiding the perennial trap in antitrust cases of focusing on fairness toward particular competitors rather than on effects on the competitive process itself. ${ }^{111}$ True boycotts are frequently employed as the main sanction in programs of selfregulation, and courts have been inclined to condemn them not only because of their nakedness but also because of their unfair and coercive impact. ${ }^{12}$ Care must be taken, however, not to allow this latter aspect to

because of their dangerous tendency, their probable lack of procompetitive virtue, and the administrative virtues of clear rules-naked boycotts are per se unlawful, subject to the exceptions noted above: R. Bork, The ANTITRust PARAdox 330-44 (1978); L. SullivaN supra note 105, at 23334, 238-41 (1977); Bauer, supra note 105, at 696-99; Dolan \& Ralston, supra note 19, at 752, 755; Kissam, supra note 105, at 1195-97; Kissam \& Webber, supra note 13, at 660-61.

110. See infra text accompanying notes 160-73 and 174-215; see also supra notes 51-82 and accompanying text.

111. See infra note 113 and accompanying text.

112. Because most of the leading boycott cases have involved boycotts aimed at competitors, it has been natural for courts to concentrate on the boycott's exclusionary character and to emphasize its unfair and coercive effects, creating the impression that the real vice of a boycott is to be found in its impact. $C f$. St. Paul Fire \& Marine Ins. Co. v. Barry, 438 U.S. 531, 542 (1978) (observing the harm to plaintiffs but also the possible irrelevance of that fact); Silver v. New York Stock Exchange, 373 U.S. 341, 347 (1963) (observing that, absent statutory authority to engage in self-regulation, the defendants would have violated the law by engaging in a group boycott depriving petitioner of a business service that he needed in order to compete effectively); Klor's, Inc. v. Broadway-Hale Stores, 359 U.S. 207, 210 (1959) (quoted and discussed supra note 107; concern expressed that "a group of powerful businessmen may act in concert to deprive a single merchant, like Klor, of the goods he needs to compete effectively"); Fashion Originators' Guild v. FTC, 312 U.S. 457, 465 (1941) (condemning a boycott by manufacturers of retailers who sold copies of designer clothing as being "in reality an extra-governmental agency, which . . . provides extra-judicial tribunals for the determination and punishment of violations"); Weiss v. York Hosp., 745 F.2d 786, 818-20 (3d Cir. 1984) (a hospital privileges case stressing the analogy to a true boycott in staff doctors' use of "their existing relationship with a supplier [i.e., the hospital] to exclude their competitors from dealing with the supplier"). In AMA v. United States, 130 F.2d 233, 248-49 (D.C. Cir. 1942), aff'd, 317 U.S. 519 (1943), the court went so far as to distinguish between professional associations' "agreements for self-discipline and control" and "an effort . . . to destroy competing professional or business groups or organizations." Id. (emphasis in original). Similarly, in emphasizing that medical societies "are not law enforcement agencies" empowered to control others, id. at 249 , the court implied that agreements by which their members nakedly surrender their decisionmaking independence would not be 
become the key element in the offense. Much that goes on in competitive markets is apt to seem unfair to some participants, and judges hearing plaintiffs' complaints of such unfairness often are tempted to convert antitrust law into a federal law against unfair competition or unequal bargaining instead of maintaining it as a program for promoting dynamic competition for the ultimate benefit of consumers. ${ }^{113}$

The doctrinal confusion that is currently found in the law of boycotts appears to have resulted from raising the unfairness element to a preeminent place and forgetting that it is the compatibility of concerted action by competitors with vigorous competition that is the critical issue in a restraint-of-trade case. Although courts usually reach correct results despite their confusion concerning these matters, they would do better to keep these distinctions and values firmly in mind. A court looking at an admitting privileges case would do well to start by declaring whether the case does or does not involve a true boycott or concerted refusal to deal. Illegality should be automatic if two or more hospitals acted in concert or if physicians agreed either to withhold referrals from the excluded provider or to take collective action against the hospital if it did not honor their preferences. ${ }^{114}$ The next section suggests how to proceed in the absence of such naked restraints.

\section{Antitrust Principles Applicable to Decisions on Admitting Privileges}

With the foregoing misconceptions out of the way, it is now possible to suggest how antitrust courts should approach privileges cases. In particular, the above showing of why fairness to competitors should be put aside as a direct concern in antitrust analysis should permit attention to

found ipso facto in restraint of trade. The case of Wilk v. AMA, 719 F.2d 207 (7th Cir. 1983), cert. denied, 104 S. Ct. $2398 \& 2399$ (1984), can be seen as extending this reasoning to a case in which competitors did feel the boycott's impact. See supra note 101. The need to reexamine boycott doctrine in light of the crucial importance of decentralized decisionmaking would seem to be acute. See infra note 115 .

113. Although it has frequently been said that antitrust law is intended to protect competition, not competitors, see supra text accompanying note 94 , this idea is finally beginning to receive more than lip service. Indeed, antitrust law appears to be in the midst of an important transition, moving from a period during which it sought to enforce fairness in business dealings between largc and small firms-at some expense to efficiency-into an era in which the dominant concern is consumer welfare, as served by efficiency in production and by hard-as opposed to judicially-inhibited-bargaining and competition. The debate concerning the transition is extensive and ongoing. See, e.g., $\mathbf{R}$. Bork, supra note 109, at 81-89; R. Posner, Antitrust LAW: AN Economic Perspective 8-22 (1976); Kissam, supra note 105, at 1169-78; Antitrust Law and Economics, 127 U. PA. L. REV. 918, 918 (1979); Antitrust Jurisprudence: A Symposium on the Economic, Political and Social Goals of Antitrust Policy, 125 U. PA. L. Rev. 1182, $1184-88$ (1977); Sullivan, Book Review, 75 ColuM. L. REv. 1214, 1220-21 (1975).

114. See supra text accompanying notes 75-78 \& 228-32. 
focus more precisely on the true issues: (1) which private entities and groups can be allowed to exercise decisionmaking responsibilities in the private sector without jeopardizing competition's role as the guarantor of consumer welfare and economic efficiency, and (2) how active a role the courts should assume in reviewing the actions of such lawful entities and groups. ${ }^{115}$ The problems of identifying the true policy goals of antitrust law and of adequately recognizing the legitimacy of private decisionmakers are important general issues in antitrust law today. ${ }^{116}$ Hospital privileges cases give courts an opportunity to address some of these fundamental issues in a new factual context uncabined by unfortunate precedent. Perhaps, then, in this new context, the courts can place appropriate weight on efficiency considerations and avoid being drawn into protecting competitors at the expense of competition.

Antitrust analyses of privileges issues have not yet succeeded in giving hospitals and their medical staffs clear guidance so that they can pursue legitimate institutional goals in reasonable safety. The most thorough examination of the privileges problem, that of Philip Kissam and his co-authors, recommends that antitrust courts, in most cases, seek to discover whether the "dominant purpose" served by a denial of privileges was an anticompetitive one; ${ }^{17}$ similar views of the judicial function

115. The confusion in the conceptualization of boycotts described supra text accompanying notes 103-14 reflects a failure to define antitrust issues in this way. The failure to draw a sharp distinction between an illegal naked boycott and the actions of a single competitor-controlled entity appears to reflect a hesitancy to concede the legitimacy of any joint activity. This hesitancy may spring either from a belief that it is desirable to preserve as many opportunities as possible to regulate private conduct or from a failure to appreciate the need to enforce a few, simple, efficiency-based rules to avoid ad hoc balancing. See infra note 121 .

A recent Supreme Court decision shows how an enterprise's legitimacy, once established, may require antitrust courts thereafter to refrain from scrutinizing the enterprise's conduct. In Copperweld Corp. v. Independence Tube Corp., 104 S. Ct. 2731, 2745 (1984), a parent corporation and its wholly-owned subsidiary were held not to be subject to suit under section 1 for conspiracy with each other. The Court's opinion underscores the importance in antitrust analysis of identifying legitimate decisionmaking entities, which can be closely scrutinized only at the time of their formation or under the section 2 prohibition of monopolization. See id. The converse of this approach is that those entities should be protected thereafter against antitrust challenges to their day-to-day business activities. The Court stated that the vice of concerted action is that it "deprives the marketplace of the independent centers of decisionmaking that competition assumes and demands." Id. at 2741. Observing that the exemption of single entities from scrutiny under section 1 leaves a " 'gap' in the Act's proscription against unreasonable restraint[s]," the Court said, "Congress left this 'gap' for eminently sound reasons. Subjecting a single firm's every action to judicial scrutiny for reasonableness would threaten to discourage the competitive enthusiasm that the antitrust laws seek to promote." Id. at 2744 . The analysis in this article extends the same policy reasoning to provide a measure of comparable protection for procompetitive joint action by a hospital and its physicians.

116. See supra note 113; infra text accompanying notes 238-74.

117. Kissam \& Webber, supra note 13, at 659-61. Other commentators' formulations of the relevant legal tests include Dolan \& Ralston, supra note 19, at 751-56 (allegation of hospital/physician "vertical" boycott should open inquiry into purpose and effects); Drexel, supra note 19, at 231- 
have been adopted in the few antitrust decisions that have dealt with the merits of privileges denials. ${ }^{118}$ These analyses seem unsatisfactory, however, because, although they recognize the need, ${ }^{119}$ they offer few shortcuts by which courts can avoid lengthy inquiry into all of the circumstances related to possible motives. ${ }^{120}$ The alternative legal analysis offered here promises to lower litigation costs and increase legal certainty by isolating some key factors that will allow many cases to be resolved quickly in favor of the hospitals. It is possible to be true to antitrust principles while sharply reducing litigation threats that currently hamper hospital efforts to control costs and improve the quality of

32 (action by hospital with market power should be scrutinized for anticompetitive purpose or effect); Address by Walter T. Winslow, Deputy Director of the Bureau of Competition, Federal Trade Comm'n, Before the Antitrust and Health Care Sections of the Minnesota State Bar Ass'n (May 25, 1983) (delegation of decisionmaking to medical staff amounts to combination or conspiracy whose actions must be examined to discover either a net adverse effect on competition or a primary anticompetitive purpose).

118. Only one such decision, which stops short of laying down definitive legal principles, has been handed down by a federal court of appeals. In Weiss v. York Hosp., 745 F.2d 786, 830.31 (3d Cir. 1984), osteopaths were granted injunctive relief against the maintenance of discriminatory standards by a medical staff of allopathic physicians said to be in control of the hospital. The only factual issue, resolved by the jury, was whether discrimination had occurred. Id. at 829 . For fuller discussion, see infra notes 145-46; see also Smith v. Northern Mich. Hosps., Inc., 703 F.2d 942, 947 48, 953 (6th Cir. 1983) (not strictly a privileges case; summary judgment granted against plaintiffs who could produce no evidence to support their charges of conspiracy and unlawful monopolization; defendants had shown medical and business reasons for their actions in referring patients). The most significant district court decisions on physician privileges are Stone v. William Beaumont Hosp., 1983-2 Trade Cas. (CCH) If 65,681 at 69,483-84 (E.D. Mich. 1983) (requirements which met legitimate needs of the hospital not anticompetitive; hospital's decision to expand cardiovascular surgery but not its catheterization laboratory was based on legitimate business, not anticompetitive, motives); Pontius v. Children's Hosp., 552 F. Supp. 1352, 1372 (W.D. Pa. 1982) (plaintiff must prove that hospital was motivated by an anticompetitive reason); Robinson v. Magovern, 521 F. Supp. 842, 919-20 (W.D. Pa. 1981) (no section 1 violation where hospital had refused to grant privileges to competent practitioner in pursuance of policy of seeking physicians willing to teach and do research as well as provide high quality services).

119. See, e.g., Robinson v. Magovern, 521 F. Supp. 842, 927 (W.D. Pa.1981) ("We can only hope that this opinion, which is the end product of . . . [four and one-half] years of effort and expense, will enable future courts to quickly narrow the issues."). See infra note 158 for further evidence of litigation burdens.

120. A few courts have granted summary judgment on the basis that the plaintiff had not shown the requisite concerted action. E.g., Smith v. Northern Mich. Hosps., 753 F.2d 942, 945, 956 (6th Cir. 1983); Feldman v. Jackson Memorial Hosp., 571 F. Supp. 1000, 1005 (S.D. Fla. 1983); Stone v. William Beaumont Hosp., 1983-2 Trade Cas. (CCH) ๆ 65,681 at 65,484 (E.D. Mich. 1983). Such holdings were probably based more on the absence of anticompetitive motives, however, than on the absence of joint action. See, e.g., Pontius v. Children's Hosp., 552 F. Supp. 1352, 1376-78 (W.D. Pa. 1982) (alleged conspirators either were part of one entity or lacked an anticompetitive motive; thus the court found no conspiracy). The conspiracy element of the offense would seem hard to disprove as a preliminary matter in view of the natural and appropriate closeness of hospital/staff collaboration on privileges issues. See infra text accompanying notes 177-78. Even if a plaintiff's case can occasionally be dismissed summarily for lack of anything inpugning the defendants' motives, a theory that turns primarily on motive will require lengthy trials in many cases and certainly does not permit much limitation of the scope of discovery. See infra note 157. 
care provided. The essential argument is that the total social benefits of narrowing the scope of judicial inquiry in particular cases will substantially outweigh the social costs that may arise through minor abuses that go undetected. 121

\section{A. The "Essential-Facilities" Doctrine.}

Some privileges cases may be governed by the so-called "essentialfacilities" doctrine. This doctrine developed in a series of cases in which a group of competitors collectively controlled some resource that other competitors needed in order to survive or to compete effectively in the marketplace. ${ }^{122}$ Despite the market dominance that the collaborating competitors in these cases enjoyed by virtue of their strategic position, the courts did not condemn their collaboration outright. Instead, because the concerted action appeared to be procompetitive and efficiencyenhancing, the courts pursued the alternative approach of requiring the

121. Per se rules of illegality in antitrust law, see supra note 67 , are justified by policy judgments about the marginal value of a greater expenditure of courts' and litigants' resources and about the desirability of predictability in rules intended to guide private conduct. See, e.g., Arizona v. Maricopa County Medical Soc'y, 457 U.S. 332, 343-44 (1982); Northern Pac. Ry. v. United States, 356 U.S. 1, 5 (1958). See also supra note 115 for authority recognizing that policy considerations may dictate insulating conduct that is not at the core of antitrust concern from close antitrust scrutiny. The strength of the presumption of validity that courts should attach to private activity is a dominant issue in modern legal theorizing on a wide range of subjects, such as the enforceability of private contracts. See, e.g., Note, Efficiency and a Rule of "Free Contract": A Critique of Two Models of Law and Economics, 97 HARV. L. REV. 978, 979-88 (1984). Resolution of questions of this kind requires recognition of the "administrative costs and the uncertainty associated with heightened judicial discretion." Id. at 981; see also Ehrlich \& Posner, An Economic Analysis of Legal Rulemaking, 3 J. LEGAL STUD. 257 (1974). The present article addresses staff privileges issues in essentially these terms, concluding that consumer welfare will be advanced if courts eschew a regulatory role in all but a narrow and well-defined set of circumstances. For a comparable argument concerning antitrust rules applicable to all kinds of vertical restraints, see Easterbrook, Vertical Arrangements and the Rule of Reason, 53 ANTITRUST L.J. 135, 153-57 (1984).

122. See, e.g., Associated Press v. United States, 326 U.S. 1, 13 (1945) (dominant news-pooling association of newspapers); United States v. Terminal R.R. Ass'n, 224 U.S. 383, 397 (1912) (joint railroad control of sole river crossing); United States v. Realty Multi-List, Inc., 629 F.2d 1351, 1355 (5th Cir. 1980) (multiple listing service); Gamco, Inc. v. Providence Fruit \& Produce Bldg., Inc., 194 F.2d 484, 486-89 (1st Cir.) (joint control of favorably located warehouse), cert. denied, 344 U.S. 817 (1952). On competitor collaboration in research and development joint ventures, see Department of Justice, Antitrust Guide Concerning Research Joint Ventures 21-24 (Nov. 1980) (indicating that a dominant venture, if lawful at all, would not be allowed to exclude competitors arbitrarily). On competitor control of access to selling space in tobacco warehouses, see Note, Antitrust Problems Raised by Private Regulation of the Auctioning of Leaf Tobacco, 106 U. PA. L. REV. 568, 576-82 (1958). Because all of these circumstances involve action of a single joint venture, they are distinguishable from cases involving naked boycotts and cannot be subjected to a rule of per se illegality. See supra text accompanying notes 103-14; cf. Virginia Academy of Clinical Psychologists v. Blue Shield, 624 F.2d 476, 484-86 (4th Cir. 1980) (appearing to characterize a physician-controlled insurance plan's discriminatory coverage of psychologists' services as a boycott-possibly, though, the reference was to the coordination of policies between two plans-but analyzing it as an essentialfacilities case would be analyzed), cert. denied, 450 U.S. 916 (1981). 
joint venture to adopt evenhanded policies in dispensing its benefits. Fair procedures thus became an absolute legal requirement, ${ }^{123}$ and substantive standards employed in granting membership in the venture or access to its benefits were examined to ensure their reasonableness. ${ }^{124}$ Under the doctrine of these cases, courts probably would be willing to scrutinize each exclusion of a competitor to see whether an abuse has occurred.

The essential-facilities doctrine, under which collaborating competitors can be forced to grant other competitors access to valuable resources or privileges, is essentially a subcategory of the rule of reason that applies to all competitor collaboration. Its rationale must be carefully observed, however, so that the doctrine will not be used automatically to deny to those who undertake desirable joint initiatives the fruits of their enterprise. A legal rule depriving collaborators of the competitive advantages flowing from their efforts would both diminish the incentive to start productive joint ventures and encourage free riders to hang back while others assume the risks of innovation. On the other hand, collective control of a vital resource does not always result from significant risk-taking or entrepreneurial inspiration, and there are therefore some situations in which antitrust courts can reduce the anticompetitive potential of a joint venture-by eliminating the "bottleneck" feature-without materially reducing the incentive to undertake similar initiatives. ${ }^{125}$ On this basis, a decisive distinction can be drawn in staff privileges situations between actions of an exclusive physician group lawfully owning and operating its own hospital and actions of a medical staff to which exclusionary powers have been delegated by hospital management. There will certainly be some instances of physician control over valuable hospital privileges in which the essential-facilities doctrine can be appropriately invoked.

Any decision by a medical staff with respect to hospital staffing and personnel policy presents a potential for anticompetitive abuse. In addition to the obvious possibility that an individual practitioner applying for admitting privileges could be turned down simply because staff physicians wished to retain for themselves the competitive advantage of access

123. On procedural requirements, see infra text accompanying notes 162-71, 195-202.

124. See, e.g., Associated Press v. United States, 326 U.S. 1, 9-12, 21 (1945) (standard stricter if applicant was competitor of member; held unreasonable); United States v. Realty Multi-Lisl, Inc., 629 F.2d 1351, 1383-85 (5th Cir. 1980) (standard that excluded part-time brokers held unreasonable); Gamco, Inc. v. Providence Fruit \& Produce Bldg., Inc., 194 F.2d 484, 487-88 (1st Cir. 1952) (space limitations found to justify selectivity), cert. denied, 344 U.S. 817 (1952).

125. Somewhat different concerns are raised when a single firm controls the allegedly vital resource - or bottleneck as it is sometimes called. The conduct of such a firm must be appraised under section 2 of the Sherman Act rather than section 1. See, e.g., Aspen Highlands Skiing Corp. v. Aspen Skiing Co., 738 F.2d 1509, 1520 (10th Cir.), cert. granted, 53 U.S.L.W. 3417 (U.S. Dec. 4, 1984). 
to the hospital, other abuses are also possible and may be harder to detect. Thus, a physician whose privileges are revoked because of an allegedly uncooperative attitude or disruptive personality may have inspired professional jealousy by being too successful or may have incurred professional displeasure by being too critical of colleagues or by competing with them in a manner that they found objectionable. ${ }^{126}$ Similarly, a formal prerequisite for admitting privileges that was entirely reasonable on its face-such as a requirement for specialty-board certification ${ }^{127}$ or for malpractice insurance coverage ${ }^{128}$ - might have been established primarily to exclude low-cost competitors. Likewise, a hospital's policy on the admission of patients under the care of nonphysician providers might easily reflect staff physicians' fear of competition over both price and therapeutic ideology. ${ }^{129}$ Finally, decisions to close the staff to new appli-

126. Cases (both antitrust and common-law) involving alleged personality defects and aberrational behavior are numerous. See, e.g., McElhinney v. Medical Protective Co., 549 F. Supp. 121, 125 (E.D. Ky. 1982), remanded for dismissal on jurisdictional grounds, No. 82-5636 (6th Cir. June 5, 1984) (unpublished slip op. available Dec. 31, 1984 on LEXIS, Genfed library, Cir file); Robinson v. Magovern, 521 F. Supp. 842, 915 (W.D. Pa. 1981); Robbins v. Ong, 452 F. Supp. 110, 112 (S.D. Ga. 1978); Miller v. Eisenhower Medical Center, 27 Cal. 3d 614, 618-21, 620 n.4, 166 Cal. Rptr. 826, 828-29, 829 n.4, 614 P.2d 258, 260-61, 261 n.4 (1980); Even v. Longmont United Hosp. Ass'n, 629 P.2d 1100, 1102 (Colo. Ct. App. 1982); Hackett v. Metropolitan Gen. Hosp., 1982-83 Trade Cas. (CCH) ๆ 65,059 at 70,943 (Fla. Dist. Ct. App. 1982); Silver v. Queen's Hosp., 63 Hawaii 430, 44143, 629 P.2d 1116, 1125 (1981); Ritter v. Board of Comm'rs, 96 Wash. 2d 503, 508, 637 P.2d 940, 943 (1981); see also W. ISELE, supra note 8 at 70-72. For a description of how messy such cases can be, see Cassidy, How a Doctor Won a \$400,000 Privileges Fight, MED. EcoN., Feb. 20, 1984, at 88105.

127. Challenges-both antitrust and common-law-to board-certification requirements have been fairly common. See, e.g., Cameron v. New Hanover Memorial Hosp., Inc., 58 N.C. App. 414, 451-52, 293 S.E.2d 901, 923, appeal dismissed, 307 N.C. 127, 297 S.E.2d 399 (1982); Sarasota County Pub. Hosp. Bd. v. Shahawy, 408 So. 2d 644, 646 (Fla. Dist. Ct. App. 1981); Armstrong v. Board of Directors, 553 S.W.2d 77, 79 (Tenn. Ct. App. 1976); see also W. IsEL.E, supra note 8, at 7375. Cases challenging a requirement of membership in a dominant medical society are more likely to be struck down, largely because of the weaker relationship to the quality of care and the apparent delegation of the power of selection to a private, competitor-controlled group. See, e.g., Foster v. Mobile County Hosp. Bd., 398 F.2d 227, 230 (5th Cir. 1968); Greisman v. Newcomb Hosp., 40 N.J. 389, 401-04, 192 A.2d 817, 824 (1963).

128. Nonantitrust cases upholding insurance requirements include Pollock v. Methodist Hosp., 392 F. Supp. 393, 398 (E.D. La. 1975); Wilkinson v. Madera Community Hosp., 144 Cal. App. 3d 436, 442-48, 192 Cal. Rptr. 593, 596-601 (1983); Renforth v. Fayette Memorial Hosp. Ass'n, 178 Ind. App. 475, 480-89, 383 N.E.2d 368, 372-77 (1978) (en banc), cert. denied, 444 U.S. 930 (1979); Holmes v. Hoemako Hosp., 117 Ariz. 403, 405, 573 P.2d 477, 479 (1977) (en banc). See W. IsELE, supra note 8 , at $82-86$.

129. Exclusion of nonphysicians has been an issue in numerous antitrust and nonantitrust cases. E.g., Weiss v. York Hosp., 745 F.2d 786 (3d Cir. 1984) (osteopath); Shaw v. Hosp. Auth., 614 F.2d 946 (5th Cir. 1980) (osteopath); Stern v. Tarrant County Hosp. Dist., 565 F. Supp. 1440 (N.D. Tex. 1983) (osteopath); Todd v. Physicians \& Surgeons Community Hosp., 165 Ga. App. 656, 302 S.E.2d 378 (1983) (podiatrist); Greisman v. Newcomb Hosp., 40 N.J. 389, 192 A.2d 817 (1963) (osteopath). On recent changes in $\mathrm{JCAH}$ standards to allow individual hospitals greater freedom to determine their own policy toward nonphysicians seeking to admit patients, see supra note 57. 
cants altogether, although possibly indicated by operational and quality considerations, might also be inspired by a desire of the "haves" on the medical staff to exclude the "have-nots." 130 Because anticompetitive motives might easily influence a medical staff's judgment on all such policy matters, the essential-facilities doctrine can fill a real need by exposing actions on privileges issues to judicial oversight.

Although the essential-facilities doctrine is a promising legal theory for plaintiffs in cases involving hospital admitting privileges, certain factual circumstances must exist before it can be appropriately invoked. Moreover, as an application of the antitrust rule of reason, the essentialfacilities doctrine leaves courts some discretion in their attempts to strike an optimal balance between the anticompetitive risks and the procompetitive benefits of collaborative action. The discussion here advocates and seeks to clarify the doctrine's application to privileges cases.

1. Uniqueness of the Hospital. Before applying the essential-facilities doctrine in a privileges case, a court must find that the hospital is truly an essential resource, access to which is necessary for a competitor to compete effectively in the marketplace at all. ${ }^{131}$ If other area hospitals are available to the applicant, a denial of privileges would not constitute, by itself, a barrier to competition with staff physicians. Moreover, the availability of alternative facilities would render fruitless a predatory denial of privileges by the medical staff, thus reducing the likelihood that the underlying motive was anticompetitive. In addition, if a hospital

130. A series of common-law cases in New Jersey in which excluded physicians challenged closures of hospital staffs appears to allow a hospital to reject qualified applicants for its own reasons but not as an accommodation to its doctors. See Guerrero v. Burlington County Memorial Hosp., 70 N.J. 344, 360 A.2d 334 (1976); Walsky v. Pascack Valley Hosp., 145 N.J. Super. 393, 411, 367 A.2d 1204, 1214 (1976) ("[T]he only significant effect of continuing the closure of staff appointments is to confine control of the institution's beds to its existing medical staff and to enhance their cconomic interests at the expense of other qualified physicians whose patients are excluded. . . If there were any credible evidence that the continuation of the moratorium contributed or was related to the quality of patient care at PVH, this court would be both obliged and eager to sustain it."); Davis v. Morristown Memorial Hosp., 106 N.J. Super. 33, 254 A.2d 125 (1969); see also Hackett v. Metropolitan Gen. Hosp., 422 So. 2d 986 (Fla. Dist. Ct. App. 1982) (state antitrust case involving a denial based on medical staff's belief that hospital had adequate coverage in the area of the plaintiff's specialty; dismissal of complaint reversed); Hoffman v. Garden City Hosp.-Osteopathic, 115 Mich. App. 773, 321 N.W.2d 810 (1982) (state antitrust case permitting denial for lack of need).

131. Essentially, the concern is with barriers to entry over which competitors exercise control. Even if a facility is the only one of its kind in the area, it is unique only if it "cannot practicably be duplicated by would-be competitors." Hecht v. Pro-Football, Inc., 570 F.2d 982, 992 (D.C. Cir. 1977) (quoting A. Neale, The ANTrtrust Laws of the United States 67 (2d ed. 1970)), cert. denied, 436 U.S. 956 (1978); accord Robinson v. Magovern, 521 F. Supp. 842, 913 (W.D. Pa. 1981); L. SUllivan, supra note 105, at 131 (facility is essential "if due to natural advantage, custom, or restrictions of scale, it is not feasible for excluded competitors to duplicate the facility"). A special factor in privileges cases that may lead to a finding that a serious entry barrier exists is the existcncc of entry regulation of hospitals under certificate-of-need laws. See supra note 91. 
faced the immediate prospect of losing business to a competing institution, its interest in preventing an inappropriate denial of privileges would be strong and would serve to protect against abuse. Thus, without the special fact of the facility's uniqueness, a denial of privileges should not give rise to antitrust concern unless a wider conspiracy could be proved. An allegation of a community-wide conspiracy linking two or more hospitals and their medical staffs would present a quite different picture; if proved, such a naked boycott should be punished as a per se violation. ${ }^{132}$

In order to determine the competitive significance of a particular facility, it is useful to define a relevant market in both product and geographic terms. ${ }^{133}$ Precision in market definition is required because, although there might be several hospitals in an area, the defendant institution might possess locational advantages or specialized facilities that make it a vital resource for antitrust purposes. ${ }^{134}$ In a lengthy opinion in Robinson v. Magovern, ${ }^{135}$ the district court defined the product market as that for adult open-heart surgery and identified a sixteen-county area in which patients could seek such surgical care. On the basis of this market analysis, the court found that the hospital in question was not a unique resource because five other hospitals were capable of offering the service that the plaintiff applicant for surgical privileges sought to provide. ${ }^{136}$

Although the court in Robinson initially defined the market in order to measure the hospital's market power, such power is not, strictly speaking, the true issue in an essential-facilities case. ${ }^{137} \mathrm{~A}$ more important consideration is the power collectively possessed by the competitor physicians who dispose the right to use the facility. A high aggregate market share possessed by physicians on the medical staff, however, does not alone signify the specific danger to competition that invites application of

132. See supra text accompanying notes 100-14; infra text accompanying notes 228-32.

133. Although the main focus in a section one case is on the collaborative conduct of the defendants, a market may need to be identified in order to determine whether the net effect of particular concerted action is likely to be anticompetitive. The importance of the market power collectively possessed by the collaborators is demonstrated supra notes $64-70$ and accompanying text. Here, however, the issue is not market power as such, see infra text accompanying notes 137-38, but the existence of a meaningful barrier to entry into a particular market over which the defendants exercise control.

134. See, e.g., Weiss v. York Hosp., 745 F.2d 786, 793-94 (3d Cir. 1984) ("tertiary care" facilities and services); Konik v. Champlain Valley Physicians Hosp. Center, 561 F. Supp. 700, 714 n.15, 719 (N.D.N.Y. 1983) (plaintiff argued that hospital was unique because of its "size, location, reputation, scope of services offered, and also due to the fact that it is the area's only referral hospital"); Pontius v. Children's Hosp., 552 F. Supp. 1352, 1366, 1377 (W.D. Pa. 1982) (pediatric thoracic and cardiovascular surgery).

135. 521 F. Supp. 842 (W.D. Pa. 1981).

136. Id. at $877-86,913$.

137. See infra note 175. Courts tend to discuss the issue in terms of market power, however. See, e.g., Weiss v. York Hosp., 745 F.2d 786, 819 n.58 (3d Cir. 1984). 
the essential-facilities doctrine. There must also be some reason to think that the doctors' market position depends upon excluding competitors from the facility in question and not upon their superior market performance. ${ }^{138}$ Nevertheless, because competitors in control of a facility that is truly essential will necessarily enjoy a high percentage share of a properly defined market, evidence of such collective market power can serve to confirm other evidence of the hospital's uniqueness.

2. Competitor (i.e., Medical Staff) Control. Another factual prerequisite to invoking the essential-facilities doctrine in a privileges case is collective control of access to the allegedly vital resource by competitors of the excluded applicant. Such a horizontal competitive relationship gives rise to a conflict of interests that could inspire anticompetitive actions. By the same token, absence of such a relationship means that the decisionmakers will not be tempted to depart from pursuing their normal business objectives in order to injure competition or competitors directly; close judicial scrutiny of their business decisions would therefore be inappropriate. Where a vertical rather than a horizontal relationship exists between a decisionmaker and those affected by its decisions, a completely different legal analysis resulting in a less rigorous test of legality is called for, as later discussion will show. ${ }^{139}$

It will not always be easy to establish a competitive relationship in a privileges case. For example, a medical staff's formal decision may have been made by a committee of physicians whose specialties differ from that of the plaintiff. ${ }^{140}$ Nevertheless, evidence that the decision was made by a disinterested committee or by a disinterested majority should not be decisive. Not only would the decision normally be based in part on infor-

138. A monopoly is not unlawful under the Sherman Act, 15 U.S.C. $\$ 2$ (1982), if it was obtained and maintained by ordinary business methods. United States v. Grinnell Corp., 384 U.S. 563, 571 (1966) (finding that the monopoly resulted from something other than "a superior product, business acumen, or historical accident"). By the same token, competitors who could collectively exercise market power are not automatically barred from collaborating for useful purposes. See supra note 64.

139. See infra text accompanying notes $193-215 \& 236-79$.

140. Cases in which it appeared that some effort had been made to remove the decision from the hands of physicians having a direct confict of interests include Stone v. William Beaumont Hosp., 1983-2 Trade Cas. (CCH) \ 65,681 at 69,482 (E.D. Mich. 1983) (Director of Medical Services, who first recommended denial of the plaintiff's application, had no personal interest); Pontius v. Children's Hosp., 552 F. Supp. 1352, 1358-59, 1371 (W.D. Pa. 1982) (credentials committee composed of independent members of medical staff); Robinson v. Magovern, 521 F. Supp. 842, 903 (W.D. Pa. 1981) (majority of reviewing committees practiced in fields unrelated to plaintiffs); see also infra notes 171-72 and accompanying text; $c f$. Applebaum v. Board of Dirs. of Barton Memorial Hosp., 104 Cal. App. 3d 648, 163 Cal. Rptr. 831 (1980) (denial of due process found where competitors participated in review). Antitrnst courts would almost certainly require staff decisions to be made by disinterested persons. See infra notes $171-72$ and accompanying text. 
mation and opinion supplied by staff members in the applicant's specialty, but the decisionmakers might also be inclined to defer unduly to their colleagues' expertise. Staff members might also be given to reciprocal recognition of each other's prerogatives in such matters. For these reasons, courts would be justified in regarding an organized medical staff, because it includes members with a strong competitive interest in the outcome, as being inevitably afflicted with a conflict of interests. They should therefore apply the essential-facilities doctrine, necessitating close judicial scrutiny, whenever a self-governing medical staff controls a personnel decision affecting a competitor of any member.

The essential fact triggering this analysis is the medical staff's final authority in the disposition of privileges. Because the essential-facilities doctrine applies only where resources are under competitor control, interposition of the hospital itself as the final decisionmaker should make the doctrine inapplicable to a staffing decision. It should not be enough to escape the doctrine, however, to show that the hospital governing board formally ratified the staff's. Even though medical staffs are generally acknowledged to be accountable to the ultimate authority of the hospital trustees or directors, in many hospitals the governing board's authority over privileges decisions is purely nominal. ${ }^{141}$ It is therefore essential that antitrust courts inquire specifically in each case whether the hospital board acted independently or simply rubber-stamped the medical staff's decision. The availability to the plaintiff of the essential-facilities doctrine should hinge on the outcome of this limited inquiry.

Probably no antitrust lawyer would quarrel with the suggestion that, in a staff privileges case, a court should be interested in whether the hospital acted independently in pursuance of its own corporate goals or instead acted as a rubber stamp for the decisions of its medical staff. But many analysts would consider this issue to be relevant only in determin-

141. See supra note 45; see also Kissam \& Webber, supra note 13, at 641 (asserting that "the hospital board functions as a reviewing court that recognizes substantial discretion in the staff'); Dolan \& Ralston, supra note 19, at 711-12 (asserting that "[f]ormalities are misleading. . . . [T] significant entity in the application process is the medical staff"). Despite these assertions of what may be commonly true, however, where power actually resides in a particular hospital is a difficult factual question. See infra text accompanying notes 146-55. For the views of an FTC official, see Winslow, supra note 117 , at $13 \mathrm{n} .11$ :

If there is no formal delegation of authority to the physician group, deciding whether the medical staff controls the granting of privileges will be a factual question much like the 'control' issue discussed in [FTC Enforcement Policy with Respect to Physician Agreement to Control Medical Prepayment Plans, 46 Fed. Reg. 48,982 (1981)]. . . . The analysis of control is 'a practical one,' asking whether the hospital's lines of authority give the staff the ability in practice to make the decision as to who receives privileges.

For a hospital administrator's advocacy of an independent role for the hospital as a protection against antitrust risks, see Stoltzfus, Credentialing Sparks Antitrust Scrutiny, MOD. HEALTHCARE, Feb. 15, 1984, at 190. 
ing whether the hospital had allowed itself to be drawn into a doctor conspiracy or into a "combination" with its medical staff. ${ }^{142}$ The analysis here, however, asserts that the hospital's decisionmaking independence is important for an entirely different legal reason. Indeed, as later discussion will show, ${ }^{143}$ the existence of a hospital/physician combination or conspiracy should not be regarded as the central issue in these cases. For one thing, hospital/physician relationships are typically so close that it will always be difficult to deny that the requisite concerted action occurred. Moreover, a hospital whose medical staff abuses its power would be liable for the illegal actions of its agents in any event, even if it in no way authorized or participated in them. ${ }^{144}$ The important observation here is that, in privileges cases, the locus of de facto decisionmaking authority within an institution determines, not whether or not there was a conspiracy, but whether the essential-facilities doctrine applies.

The courts that have reached the merits of antitrust cases involving hospital admitting privileges so far have not relied primarily upon the essential-facilities doctrine. ${ }^{145}$ As a result, they have not fully recognized

142. See, e.g., Kissam \& Webber, supra note 13, at 638-42; Dolan \& Ralston, supra note 19, at 752-55 (discussing "vertical boycott").

143. See infra text accompanying notes 176-93.

144. In American Soc'y of Mechanical Eng'rs, Inc. v. Hydrolevel Corp., 456 U.S. 556, 570.74 (1982), a professional association engaged in product certification was held liable for antitrust violations committed by its voluntary agents acting with apparent authority. For antitrust purposes, a hospital's responsibility for preventing anticompetitive abuses would probably be held, like that of the defendant society in Hydrolevel, to be nondelegable in the sense that liability cannot be escaped by appointing an independent contractor (the medical stafi) to discharge it. $C f$. Weiss v. York Hosp., 745 F.2d 786, 828-30 (3d Cir. 1984) (without explanation, court enjoined hospital from discriminating against osteopaths even though it held hospital had not been a party to staff's unlawful conspiracy).

It is notable that the entire medical staff, not just the members of its privileges committee, might also be made a defendant. Cf. Corleto v. Shore Memorial Hosp., 138 N.J. Super. 302, 311-12, 350 A.2d 534, 539 (1975) (staff may be sued as an unincorporated association for negligently allowing an unskilled physician to use the hospital). See generally Harris, Vicarious Antitrust Liability in the Health Care Field, 5 CAMPBELL L. REv. 61, $105-16$ (1982); Horty \& Mulholland, Legal Differences Between Investor-Owned and Nonprofit Health Care Institutions, in THE NEW HEALTH CARE Fon ProfiT, supra note 6, at 17. Individual physicians are frequently sued as co-conspirators. See infra text accompanying note 224.

145. The latest case comes quite close to adopting this analysis, however. In Weiss v. York Hosp., 745 F.2d 786 (3d Cir. 1984), the court, assuming physician control, see infra note 146, stressed the vital character of the hospital, 745 F.2d at 793-94, and relied upon crucial language in a leading essential-facilities case, id. at 815-16 n.49 (quoting Associated Press v. United States, 326 U.S. 1, 15 (1945)). In addition, the court's close scrutiny of the action taken and the injunctive relief granted, 745 F.2d at 830, were consistent with what would be anticipated under the essential-facilities doctrine. Other cases mentioning the doctrine include Smith v. Northern Mich. Hosps., 730 F.2d 942, 953 (6th Cir. 1983) (inapplicable to hospital decision); Pontius v. Children's Hosp., 552 F. Supp. 1352, 1370 (W.D. Pa. 1982) (similar); Robinson v. Magovern, 521 F. Supp. 842, 913 (W.D. Pa. 1981) (facility not essential). 
the central importance for antitrust purposes of the hospital's role in the making of particular decisions. Although in some cases the hospital's governing board plainly acted independently, courts have not clearly regarded that fact as calling for any different legal test than would be applied if the actual decisionmakers were physician competitors of the plaintiff. ${ }^{146}$ The result of this inadequate analysis may be that staffing decisions are exposed to the same burdensome in-depth scrutiny whether or not the actual danger of anticompetitive abuse was equivalent to that found in the cases establishing the essential-facilities doctrine. It seems unavoidable that courts that fail to distinguish between hospital- and physician-dominated decisions will be more demanding in some situations and less demanding in others than is warranted by vital antitrust concerns. Thus, particular attention must be given to identifying those cases that require special judicial vigilance.

The rationale of the essential-facilities doctrine strongly suggests that close judicial regulation of privileges decisions is required only in those cases where the relationship between a decisionmaker and the party affected by the decision is more nearly horizontal than vertical. Thus, a hospital seeking to avoid application of the doctrine's stringent legal test should be expected to show that its role in a privileges decision was sufficiently real and independent to establish the decision's nonhorizontal character. One might argue of course that the hospital should be presumed to be acting independently and in its own interest even when it simply delegates decisions to the medical staff and that therefore the essential-facilities doctrine should apply only if this presumption is overcome by affirmative evidence of hospital abdication. Certainly economic theory would support such a presumption, and it is indeed very possible that a hospital board submitting personnel matters entirely to staff control has satisfied itself that staff physicians do conscientiously discharge their responsibilities to the hospital. ${ }^{147}$ Nevertheless,

146. In Weiss v. York Hosp., 745 F.2d 782 (3d Cir. 1984), the court appeared to presume staff control over privileges without analysis of the facts, apparently relying on the general assertions concerning power relations in hospitals quoted supra note 141 from the Kissam \& Webber and Dolan \& Ralston articles. 745 F.2d at 796 \& n.14. Action on plaintiff Weiss' application seemed clearly to have been taken by the hospital board acting independently, but there were signs that general policies toward the entire plaintiff class (osteopaths) were those of the medical staff, not the hospital. See, e.g., id. at 795 (board and staff had different policies toward osteopaths between 1974 and 1976). On the (correct) lessons drawn from the case by an administrator of the defendant hospital, see Stoltzfus, supra note 141. Other cases in which hospital independence seemed clear but was not stressed to the extent that would be appropriate under the analysis adopted in this article include Miller v. Indiana Hosp., 572 F. Supp. 1259, 1269 (W.D. Pa. 1983) (board held hearing); Robinson v. Magovern, 521 F. Supp. 842, $875-76$ (W.D. Pa. 1981) (committee of trustees reviewed staff decision).

147. An FTC official opines as follows: 
the noncommercial orientation of many hospitals, ${ }^{148}$ the unreliability of the market forces constraining their behavior, ${ }^{149}$ and the record of physician dominance ${ }^{150}$ suggest major weaknesses in any assumption that hospital interests govern all privileges decisions. The antitrust rule of reason is appropriately applied to single out for close scrutiny those cases in which physician control creates a particular danger of anticompetitive abuse. ${ }^{151}$

Although the policy underlying the essential-facilities doctrine provides guidance in deciding specific cases, a substantial grey area exists between actions in which the hospital is clearly an independent participant and those which are clearly under physician control. ${ }^{152}$ Nevertheless, there are a number of things that a hospital can do to avoid falling into this grey area and thus to minimize the risk that its personnel actions will be exposed to close scrutiny. It can make sure that the minutes of its board meetings reveal that privileges decisions were fully reviewed by either the full board or a committee thereof. It can also make a record showing that the evidence supporting the medical staff's recommendation was evaluated-perhaps by outside evaluators-in light of the staff's possible conflict of interests and that the board weighed hospital interests that the staff was not in a good position to consider. ${ }^{153}$ Thus, the board

[A]bsent any indication that the medical staff coerced the hospital into delegating to it the power to grant or deny privileges, I think we should start with the assumption that the delegation serves the legitimate purposes of the hospital and that the hospital would revoke the authority should the medical staff abuse its power over privileges by putting the competitive interests of staff physicians above the hospital's interests.

Winslow, supra note 117 , at 15 . This presumption leaves the plaintiff with a heavy burden of proof even if the hospital has taken no active part in the decision. Although sound as a matter of economic theory, a presumption of regularity seems to ignore the marketplace realities mentioned in the text and the less-restrictive-alternative principle, the application of which to these facts is further explained infra text accompanying notes 184-88.

148. See supra notes $30-31$ and accompanying text.

149. Though market forces are gathering strength, supra text accompanying notes 14-17, their inherent imperfections-stemming from third-party payment, high concentration, and consumer ignorance-may create opportunities for medical staffs to assume and abuse power over the markct opportunities of their competitors.

150. See supra notes $39-50$ and accompanying text.

151. For discussion of how the less-restrictive-alternative principle applies to hospital/physician relations and confirms the conclusion here, see infra text accompanying notes 184-88.

152. See supra note 141. The typical case is likely to reveal only board concurrence in a staff recommendation, and it may not be clear whether the board had its own grounds for the decision and examined the reasonableness of the staff's conclusions in light of the evidencc and any possible conflicts of interests. If the hospital has made no better record than this, the issue would be one for the trier of fact and resolvable only in light of all the evidence. An FTC official, however, has suggested that a hospital's action should be "presumed to be based on the hospital's own legitimate needs." Winslow, supra note 117, at 17. This presumption, too, like the opposite presumption that the medical staff is always in charge of staffing matters, seems misplaced. See supra note 146 and notes 147-51 and accompanying text.

153. See infra text accompanying notes $225-27$. 
should pay particular attention to the increased business that could fiow to the hospital via a particular applicant or via strengthened competition between physicians. ${ }^{154}$ A hospital might also be well-advised to discontinue the particular method that was prescribed until recently by the JCAH for resolving situations in which the board's judgment differs from the staff's. ${ }^{155}$

Besides focusing specific attention on the crucial antitrust question whether a vertical or a horizontal relationship exists between a decisionmaker and the party affected by a particular privileges decision, an inquiry into the locus of decisionmaking in the hospital can facilitate the early termination of litigation. As subsequent discussion will show more fully, ${ }^{156}$ courts should engage in close scrutiny of a particular hospital action only in cases where the essential-facilities doctrine applies. Thus, because evidence that the medical staff was not the true decisionmaker can be elicited prior to full discovery, a court should be able, in many cases, to grant summary judgment or a directed verdict on the basis of only a limited review of the action taken. Other analyses of privileges cases appear not to have arrived at principles that can spare hospitals the heavy burden of defending their actions in depth. ${ }^{157}$ Not only is it costly to reconstruct through discovery, depositions, and trial all the complex

154. A hospital that is not fully utilized is likely to favor additions to its medical staff, perhaps in the belief that more physicians of certain types can create demand for services. See, e.g., Fuchs, The Supply of Surgeons and the Demand for Operations, 13 J. HuM. Resources 35, 54 (1978). Also, to the extent that consumers are price-conscious and price competition lowers physician fees, a hospital could find that competition between physicians, by reducing the total price, increases demand for services provided in the hospital. As models such as PPOs, see supra note 4, become more prevalent, hospitals may increasingly see a benefit to themselves from encouraging competition between physicians.

155. The JCAH previously provided that a joint committee of board and staff members was to review such differences of opinion before the board acted finally. 1983 MANUAL, supra note 47, at 55-56. This requirement appeared to make the board accountable to the staff, in some measure, rather than the other way around. See Kissam \& Webber, supra note 13, at 640-41. The 1984 MANUAL, supra note 8 , at 50 , requires only that "differences are resolved within a reasonable period of time by the governing body and the medical staff," but this provision, too, suggests that the board must not act on its own. A hospital that seems to negotiate its differences with the staff, though technically it satisfies the independence requirement suggested herein, runs some risk of being found in a conspiracy with its staff and of having its actions on privileges matters closely scrutinized. By the same token, a medical staff that engages in collective bargaining approaches the line of illegality mentioned supra in text accompanying notes 74-78. In general, although formation of a hospital/ physician joint venture should be regarded as procompetitive when it occurs voluntarily, compulsion of hospitals by the physician-dominated JCAH to share authority with physicians might reasonably be deemed to weaken or destroy the ordinary presumption that the joint venture was organized to promote efficiency. Thus, the favorable interpretation of hospital/physician joint ventures recommended infra in text accompanying notes 176-93 may not be warranted as long as the JCAH inhibits hospitals in designing their relationships with physicians.

156. See infra text accompanying notes 159-73 \& 215-24.

157. See supra notes $117-20$ and accompanying text. 
circumstances surrounding a particular personnel action, ${ }^{158}$ but the social costs of exposing hospitals to heavy litigation burdens are not measured by litigation expense alone. ${ }^{159}$

\section{The Tests Employed in Reviewing Medical-Staff Decisions.}

Even if the essential-facilities doctrine is applicable under the foregoing analysis to a particular personnel action by a hospital medical staff, a question remains as to the nature, scope, and standards of judicial review of that action. As an embodiment of the antitrust rule of reason, the essential-facilities doctrine leaves considerable room for judgment in assessing the actions of a particular joint venture and for tailoring the court's intervention in proportion to the risk of anticompetitive harm. Because courts in privileges cases have not fully recognized the significance of competitor control, there is some danger that their approach will sometimes be too deferential or not sufficiently penetrating to discover and penalize abuses by the medical staff of its dominant position. It is argued here that, if the essential-facilities doctrine is properly applicable on the facts, a court should be fairly rigorous in evaluating actions of a medical staff in restricting access to the hospital by competitors of its members.

A general judicial policy of according the benefit of the doubt to all personnel actions in hospitals ${ }^{160}$ might seem defensible on the same

158. Numerous cases reveal the burdens of staff privileges litigation. See, e.g., McElhinney v. Medical Protective Co., No. 82-5636 (6th Cir. June 5, 1984) (unpublished slip op. available Dec. 31, 1984 on LEXIS, Genfed library, Cir file) (recites ten-year history of dispute; case finally dismissed on jurisdictional grounds); Feldman v. Jackson Memorial Hosp., 571 F. Supp. 1000, 1004 (S.D. Fla. 1983) (hospitals obtained a directed verdict after plaintiff spent five weeks presenting his evidence); Robinson v. Magovern, 521 F. Supp. 842, 848 (W.D. Pa. 1981) (three years of discovery and a tenweek trial).

159. See infra note 216 and accompanying text.

160. A distinction exists between the degree of deference accorded a particular decisionmaker and the degree of scrutiny given a particular action. Deference governs the extent to which a court will consider the objective validity of stated criteria, reweigh the evidence of an applicant's fitness, or substitute its judgment about the relative importance of different criteria. Courts generally appear to have given great deference to the decisions of hospitals and medical staffs regardless of which entity made the decision. See, e.g., Stone v. William Beaumont Hosp., 1983-2 Trade Cas. (CCH) \ 65,681 at 69,484 (E.D. Mich. 1983) (summary judgment granted where the defendants had offered "legitimate reasons" for denying privileges and the plaintiff failed to produce "sufficiently probative evidence" to create a question of fact); Pontius v. Children's Hosp., 552 F. Supp. 1352, 1373 (W.D. Pa. 1982) (court looked only to see whether the decision of a physician committee was arbitrary or capricious); Williams v. Kleaveland, 534 F. Supp. 912, 918-19 (W.D. Mich. 1981) (criteria would be upheld if they were "reasonably related to the hospital's legitimate institutional objectives," not an unreasonable restraint of trade, and not imposed as a sham). Several nonantitrust cases reveal the same attitude even toward physician-dominated decisions. See, e.g., Sosa v. Board of Managers of Val Verde Memorial Hosp., 437 F.2d 173, 176-77 (5th Cir. 1971) (in a civil rights action, court stated that physicians' evaluation of a peer's professional competence should be given "limited judicial surveillance"); Settler v. Hopedale Medical Found., 80 Ill. App. 3d 1074, 1076, 400 N.E.2d 577, 
grounds that led the Supreme Court in Silver v. New York Stock Exchange ${ }^{161}$ to recognize that the defendant stock exchange needed some "breathing space" in which to carry out its statutory self-regulatory functions without undue exposure to antitrust risks. ${ }^{162}$ Nevertheless, similar deference to the actions of collaborating competitors would be inappropriate here. Under the rule of reason, a policy of protecting a joint venture against risks of liability that may inhibit its functioning should be adopted only if the collaborators had available to them no less restrictive alternative method to accomplish their valid purposes. ${ }^{163}$ Where a medical staff exercises de facto control over access to a hospital, there clearly exists another way-namely, submission to the authority of the hospital board-for the staff to accomplish its procompetitive purposes ${ }^{164}$ without the same danger to competition. Although a court should not condemn the staff's exercise of delegated powers on that ground alone, ${ }^{165}$ neither should it presume the regularity of the staff's decisions or accord any special deference to the action taken in a given case. ${ }^{166}$

Where the facts support application of the essential-facilities doctrine, a court would be justified in subjecting medical-staff actions on personnel matters to strict requirements and close oversight. Thus, it might reasonably require that fair procedures be followed and award treble damages where they are not. The Silver case is authority for denying the medical staff the opportunity to show in court that, despite the omission of procedural protections, good grounds existed for the action taken. In that case, the district court required defendant stock exchange, a self-

579 (1980) (decision to deny privileges is not subject to judicial review); Guerrero v. Burlington County Memorial Hosp., 70 N.J. 344, 356, 360 A.2d 334, 340 (1976) (denial of privileges by a board of trustees must not be arbitrary or capricious). The argument herein is that deference should take the form of limited scrutiny and a willingness to terminate litigation early in cases where useful activities have been structured to minimize the risk of anticompetitive harm.

161. 373 U.S. 341 (1963).

162. Id. at 360 . The Court also indicated that antitrust liability would be imposed only for procedural failings that fell "too far outside the scope" of the defendants" warrant for collective action, $i d$. at 362, and that the substantive test for legality of actions taken, though not decided, would probably not be unduly rigorous-“"a standard of arbitrariness, good faith, reasonableness, or some other measure," id. at 366.

163. See infra notes $184-88$ and accompanying text.

164. See supra text accompanying notes 63-67.

165. Even though a hospital and its medical staff could easily minimize the danger to competition by structuring their decisionmaking processes differently, the usual justification for a per se rule is not present here. Not only is the probability of actual anticompetitive effects not high enough to punish the conduct without proof thereof, but the need for a bright-line rule to simplify litigation and guide private conduct can be met by varying the level of scrutiny as recommended herein.

166. See supra notes 147-52 and accompanying text. As explained further infra text accompanying notes 184-88, the less-restrictive-alternative principle of rule of reason analysis is appropriately invoked to insure that powerful competitors do not exercise powers that are broader than necessary to accomplish their legitimate purposes. 
regulatory body that had ordered its members to terminate their wire connections with the plaintiff-a competing broker-, to pay treble damages because the exchange had not allowed the broker to know and reply to charges concerning his character. ${ }^{167}$ The court reached this result without allowing the exchange an opportunity to show that it had acceptable reasons for its action.

As the Supreme Court made clear, the Silver case, unlike the typical staff privileges denial, involved a true boycott by the exchange members that would have been a per se antitrust violation if a special statute had not expressly authorized the exchange's program of self-regulation. ${ }^{168}$ The Court imposed its strict requirement of fair procedures as a way of reconciling the conflict between that statute and the Sherman Act; essentially, the Court required fair procedures as a less restrictive alternative that, if adopted, would have substantially reduced the hazard to competition presented by the exchange's exercise of self-regulatory powers. ${ }^{169}$ Although a hospital medical staff is guilty of neither a boycott ${ }^{170}$ nor any other per se violation when it denies admitting privileges to an individual, only a modest extension of the Silver reasoning is required in order to find that a medical staff, acting alone, violates the law if it neglects to employ fair procedures in a particular case. Moreover, the Silver Court's suggestion that procedural requirements should not be made too rigorous in order that the exchange would have "breathing space" in which to perform its useful functions does not carry over with much force to a situation in which an even less restrictive alternative-hospital controlis also available. Firm insistence on procedural fairness in an essentialfacilities case seems indicated. ${ }^{171}$

167. Silver, 373 U.S. at 361.

168. 373 U.S. at $347,348-49$.

169. 373 U.S. at 361-67; see infra notes 184-88 \& 195-97.

170. See supra text accompanying notes 103-14.

171. Requirements would include notice of allegations or grounds for denial and an opportunity to respond. See Vuciecevic v. MacNeal Memorial Hosp., 572 F. Supp. 1424, 1429 (N.D. Ill. 1983); Branch v. Hempstead County Memorial Hosp., 539 F. Supp. 908, 915-16 (W.D. Ark. 1982). An applicant would also enjoy the right to have his case investigated and heard by staff members having no interest in the outcome. See Robbins v. Ong, 452 F. Supp. 110, 116 (S.D. Ga. 1978) (a doctor's peers may determine his competency so long as they are not prejudiced); Applebaum v. Board of Directors of Barton Memorial Hosp., 104 Cal. App. 3d 648, 659-60, 163 Cal. Rptr. 831, 837-38 (1980) (due process denied when physicians reviewing the plaintiff's work were probably not impartial); $c f$. Blalock v. Ladies Professional Golf Ass'n, 359 F. Supp. 1260, 1265 (N.D. Ga. 1973) (suspension from golf tournaments imposed by plaintiff's competitors without hearing held illegal). A court might also hold that a meaningful right of appeal to the hospital board was required. Although such a requirement might seem to yield the same result as the analysis in this articlenamely, assurance of hospital involvement in privileges decisions-, a hospital board acting only in an appellate capacity may neglect to introduce the hospital's own interests into the decisionmaking calculus. Because the hospital's interests may differ from the medical staffs concerns, assertion of the former is necessary to render the essential-facilities doctrine inapplicable. 
In addition to insisting upon fair procedures, a court in an essentialfacilities case should closely examine the medical staff's specific requirements for admitting privileges in order to ascertain whether they do in fact serve the hospital's business interests. Courts should also be willing to investigate in depth the circumstances surrounding each staffing and personnel decision and to judge the decision's merits under a fairly demanding standard of review. The suggestion by Professor Kissam and his co-authors that courts should seek to ascertain the "dominant purpose" underlying various staff actions may be a reasonable way of framing the question in such cases. ${ }^{172}$ Essentially, the issue would be whether the staff was primarily serving its own or the hospital's interests. Not only would close scrutiny of all the facts-full discovery and a full trial-be necessary, but the action should be evaluated without the benefit of any favorable presumption or deference stemming from the professional status of the decisionmakers ${ }^{173}$ or the apparent value to the public of the functions being performed. In short, a medical staff that assumes the power to act for the hospital in these matters should be subject to strict accountability for its actions.

\section{B. Judicial Review of Hospital Actions.}

Even if the essential-facilities doctrine does not apply in a particular case because the medical staff did not itself make the decision to deny privileges, section 1 of the Sherman Act may still be invoked as a basis for scrutinizing hospital/physician interaction in controlling access to a unique facility. But, where a hospital participates independently in the making of a privileges decision, antitrust analysis should recognize how the vertical nature of the hospital's interest reduces the risk that consumer welfare will be harmed ${ }^{174}$ and thus reduces also the need for judicial oversight. Privileges decisions that are not dominated by a medical staff comprising competitors of those seeking access to the hospital should be subject to no more judicial scrutiny than can be exercised without exhaustive discovery or a full trial. Such a test, sparing the hospital

172. Kissam \& Webber, supra note 13 , at $659-61$. This test may be too favorable to a medical staff, however, because it leaves no obvious room for finding a violation if the staff's actions were influenced by a conflict of interests, but other factors are claimed to be dominant. A more rigorous test would ask whether the decision was in fact based on sound hospital policy. The other tests proposed by commentators, supra note 117 , and stated in the cases, supra note 118, do not differ greatly and leave room for substantial flexibility. Perhaps the key point is that courts, once they recognize both that a real danger to competition exists and that the defendants could have reduced that danger by differently allocating decisionmaking authority, will be less likely to err on the side of leniency toward professional decisionmakers.

173. See supra text accompanying notes $95-102$.

174. See supra text accompanying note 139 . 
undue burdens as it pursues its corporate goals, should apply even when the hospital possesses a clear monopoly because of the uniqueness of its facility, and thus exercises life-and-death power over a practitioner's right to practice in an area. ${ }^{175}$ More controversially, this test should apply even in the face of an allegation that the hospital, though acting independently, conspired with its medical staff. Before discussing the precise legal standard to be employed in reviewing hospital actions, the legal basis for limiting judicial scrutiny of actions allegedly emanating from a hospital/physician conspiracy must be explained.

1. The Hospital as a Joint Venture. A hospital's purely unilateral decision determining which health care practitioners may admit patients to its facility should be subject to virtually no review at all by an antitrust court. ${ }^{176}$ But disappointed applicants for admitting privileges can be expected to allege in every case that the hospital acted not alone but in concert with its medical staff. Furthermore, the evidence of decisionmaking independence that would allow a hospital to escape application of the essential-facilities doctrine would normally not be sufficient to overcome an allegation of a hospital/staff conspiracy. ${ }^{177}$ Also, because the typical working relationship between a hospital and its medical staff involves closely communicating and conferring on mutual objectives, defendants would find it hard to avoid a full trial of any allegation that they acted in concert. ${ }^{178}$ Thus, as long as the existence of a combination or conspiracy is perceived to be the central issue in a privileges case, the goal of sparing hospitals the litigation burdens that accompany close antitrust scrutiny is unlikely to be attained. ${ }^{179}$ It is argued here, however, that, although con-

175. Antitrust law provides little, if any, warrant for forcing a firm that possesses lawful market power to treat fairly noncompetitors with whom it deals. United States v. Colgate \& Co., 250 U.S. 300,307 (1919) (recognizing right of a trader, acting without monopolistic intent, "freely to exercise his own independent discretion as to parties with whom he will deal"); Kartell v. Blue Shield, 47 ANTItrust \& TRAde REg. REP. (BNA) 1051, 1056 (1st Cir. Nov. 28, 1984); (health insurer with lawful monopsony power cannot be prevented from insisting that physicians accept its payments as payments in full); Official Airline Guides, Inc. v. FTC, 630 F.2d 920, 925-27 (2d Cir. 1980), cert. denied, 450 U.S. 917 (1981) (publisher of dominant airline schedules could not be barred under FTC Act from discriminating arbitrarily against commuter airlines).

176. See supra note 175 on the invulnerability of a lawful monopoly to suit by or on behalf of noncompetitors.

177. Even though a hospital decision might be independent in the sense that it was not delegated to the medical staff, it would not necessarily be wholly unilateral. See infra text accompanying notes 214-15.

178. On the difficuity of dismissing conspiracy charges, see supra note 120 .

179. One way of avoiding the problem that has appeared attractive to some courts and commentators has been to argue that no conspiracy can exist between a corporation and its employees or other component parts. In Weiss v. York Hosp., 745 F.2d 786, 816-17 (3d Cir. 1984), the court held that the staff as an entity was "an officer of the corporation" and could not conspire with it; the staff itself was held, however, to be a combination of competitors subject to antitrust scrutiny. For other 
certed action is almost always present, that fact alone should not trigger close scrutiny of every denial of privileges.

Courts and other analysts tend to focus on the conspiracy issue in privileges and similar cases because they are primarily interested in questions of motive and intent. ${ }^{180}$ Unschooled in analytical techniques for determining when concerted action is truly "in restraint of trade," lawyers and judges are most comfortable in concentrating on whether the conduct in question deserves the pejorative label of "conspiracy." The appropriateness of this label depends, they think, upon the collaborators' purposes, and thus these cases tend to degenerate into lengthy courtroom battles over the purity of the motives of the bigger parties in dealing with the smaller. Indeed, to most lawyers and judges, such struggles between the apparently strong and the apparently weak are what antitrust law is mostly about, ${ }^{181}$ and it is difficult to persuade them that consumers have a stake in leaving the resolution of most such conflicts to the marketplace and in concentrating judicial energies on the protection of the competitive process itself rather than individual competitors.

Unfortunately, if one gives in to the propensity to frame the issue in hospital privileges cases as a search for improper motives, there is little opportunity to limit the inquiry and spare responsible hospitals the costs and risks of defending their business judgments. The analysis here achieves more satisfying results, first, by addressing these cases in structural terms that permit the identification of legitimate decisionmakers and, then, by protecting those decisionmakers against having their motives in making day-to-day business decisions closely scrutinized and perhaps misinterpreted. Fortunately, the treatment of privileges cases solely as an investigation of motives is not yet so well established that a differ-

applications of the single-enterprise principle and recognition of the exception for cases in which the employee has an independent personal interest in achieving the object of the conspiracy, see Smith v. Northern Mich. Hosps., Inc., 703 F.2d 942, 950-51 (6th Cir. 1983); Stone v. William Beaumont Hosp., 1983-2 Trade Cas. (CCH) \ 65,681, at 69,480 (E.D. Mich. 1983); Pontius v. Children's Hosp., 552 F. Supp. 1352, 1374 (W.D. Pa. 1982); $c f$. Nurse Midwifery Ass'n v. Hibbett, 549 F. Supp. $1185,1189-90$ (M.D. Tenn. 1982) (physician/director of insurance company had personal interest in denying renewal of plaintiff's coverage).

180. The focus on motive as the key to finding a conspiracy appears in the privileges cases cited supra note 118. Boycott cases are often approached in the same way. See supra note 109. Vertical restraint cases frequently get bogged down in trying to distinguish between parallel and shared motives. See, e.g., Valley Liquors v. Renfield Importers, 678 F.2d 742, 744 (7th Cir. 1982) (noting a "certain unreality in careful parsing of motives").

181. See, e.g., Kissam, supra note 105, at 683 (arguing for antitrust doctrine focusing on individual rights). There is a perennial tension between consumer welfare and the freedom-of-traders doctrine of United States v. Colgate \& Co., 250 U.S. 300 (1919), on the one hand, see supra note 175, and concern for the interests of terminated or disadvantaged distributors, on the other, see infra notes 222-23, 238-80 and accompanying text. 
ent approach cannot be adopted. ${ }^{182}$ Moreover, as later discussion will show, general antitrust principles do not fit hospital/physician relationships so closely that the courts' approach to these particular issues is necessarily settled once and for all by analogy to the law applicable to other situations. ${ }^{183}$

Under the rule of reason, a joint venture between a hospital and its medical staff, like the collaboration of physicians in forming a medical staff, should be regarded as procompetitive and beneficial to consumers. ${ }^{184}$ In general, where a venture contributes to efficiency, but nevertheless wields power posing a significant danger to competition, ${ }^{185}$ an antitrust court must consider whether the benefits of the arrangement outweigh its possible harms. A principle useful in this rule of reason inquiry holds that a procompetitive purpose cannot justify a significant incidental restraint of trade if a different set of arrangements-a less restrictive alternative - would have materially improved the likelihood of net procompetitive results. Although this less-restrictive-alternative principle has not been made a firm legal requirement and would be destructive if it were applied so rigorously as to make the best always the enemy of the good, ${ }^{186}$ it appears to be helpful in defining the type of

182. The most recent case, Weiss v. York Hosp., 745 F.2d 768 (3d Cir. 1984), is not inconsistent with the analysis herein. See supra note 145 . Other cases investigating motives seem to use motive as a way to determine whether a conspiracy exists. Under the analysis suggested here, the motives of the defendants would be less important at the summary judgment stage as courts focus on the structure of the hospital/staff relationship. Motives (and the presence of a conspiracy) would become important only after the court had found that the hospital/staff relationship creates a substantial threat to competition.

183. See infra text accompanying notes $238-80$.

184. See supra text accompanying notes 62-70. The combining of complementary resources in an integrated enterprise is a well-recognized basis for applying a rule of reason approach and rejecting condemnation of a practice as a per se violation. See, e.g., United States v. Pan Am. World Airways, 193 F. Supp. 18, 32-33 (S.D.N.Y. 1961) (the combination of defendants" "physical and technical resources assured the maximum possibilities of success in instituting and carrying on a pioneering venture, useful to the community"), rev'd on other grounds, 371 U.S. 296 (1963).

185. See supra note 64 .

186. For any joint venture involving both procompetitive and anticompetitive potential, a less restrictive alternative (LRA) achieving the same benefits can very often be imagined. Assuming one still is satisfied that the true purpose is in fact the one claimed, the proper test is one of reasonableness. See supra note 67. Although the LRA requirement makes sense where substantially the same benefits could have been obtained with significantly less risk to competition, courts should avoid exercising hindsight to make unreasonable demands that could effectively chill joint ventures by creating legal uncertainty. See P. AREedA, supra note 73, at 8-10 ("the key difficulty in examining less restrictive alternatives lies in deciding how refined a distinction to make among the possible alternatives available"). A crucial point, noted infra text accompanying note 189 , is that a court should apply the LRA doctrine in evaluating the structure of the joint enterprise, not its every act or omission. See Havighurst \& King, supra note 57, at 176-78.

The Supreme Court was unreasonably demanding in United States v. Topco Assocs., Inc., 405 U.S. 596, 610-12 (1972). Failing to appreciate the distinction between naked and ancillary restraints, the Court insisted on applying the per se rule against market division, see supra note 69 , to a joint 
relationship that hospitals must maintain with their physicians. Indeed, it seems clear that the less-restrictive-alternative principle lies at the heart of the essential-facilities doctrine and strongly supports the conclusion derived from that doctrine in earlier discussion ${ }^{187}$ - namely that a hospital that acts in conjunction with its medical staff must face strict judicial scrutiny unless it maintains an independent check on staff activities that endanger competition. The Supreme Court's requirement of fair procedures in the Silver case was a reflection of the less-restrictive-alternative requirement and is a strong precedent for a policy requiring hospitals to act affirmatively to minimize the danger that physicians' conflicts of interests will infect hospital decisions. ${ }^{188}$

Although a court should examine whether the collaboration between a hospital and its medical staff was structured to avoid undue risks to competition, it should not go further and attempt to verify that every specific action by the combination was inspired by pure motives or was actually beneficial to the competitive process or to consumers. ${ }^{189}$ A rule

venture by several retail grocers to develop a private brand that enabled them better to compete with larger chains. Topco, 405 U.S. at 607-08. Restrictions on the areas in which the members could market the brand were condemned despite the need for such restrictions to protect, against "free riders," each grocer's investment in developing the brand's good will. Id. at 605-06, 610-11. The only reading of Justice Marshall's opinion that makes any doctrinal sense is that he considered the power of the venture great enough to raise a danger to competition, found little procompetitive benefit in the development of a private brand, and felt that the venture's legitimate objectives could be adequately achieved by an LRA, such as that eventually permitted on remand. 1973-1 Trade Cas. (CCH) $₫ 74,391$ (N.D. Ill.), aff'd mem., 414 U.S. 801 (1973). This reading of the case-as a borderline application of the LRA requirement to resolve a close question concerning the net effect of a practice on competition-seems necessary if the holding is not to invalidate a great deal of useful collaboration. Although the Court made a series of highly dubious factual judgments in reaching its ultimate result, later courts are free to be more sensitive to the danger of chilling procompetitive initiatives through legal uncertainty and to be less formalistic in their judgments of possible effects.

A somewhat more satisfying application of the LRA requirement appears in United States $v$. Realty Multi-List, Inc., 629 F.2d 1351, 1369-87 (5th Cir. 1980). Recognizing the procompetitive advantages of a multiple-listing service, the court-by reviewing membership criteria to ensure that they served legitimate needs of the joint venture and were reasonably necessary thereto-sought to protect against the risk that the service would use its membership requirements to disadvantage would-be competitors of its members. Although the court might seem to have quibbled unnecessarily at a few points, see, e.g., id. at 1381, its holdings on these specific matters might be viewed, not as invalidating such conditions if found standing alone in an otherwise reasonable setting, but as necessary to remedy the clear abuses found in the overall arrangement.

187. See supra text accompanying notes $139-72$.

188. See supra text accompanying notes 160-71.

189. Debate persists over whether the antitrust laws are intended to promote competition exclusively in order to enhance consumer welfare or are intended to promote other, noneconomic values as well, such as faimess and deconcentration of business. See supra note 113. Occasionally, the consumer-welfare principle is adopted but misapplied by judges who attempt to ascertain not simply whether competition was impaired-presumptively to the detriment of consumers-but whether a particular practice undertaken by a competitor for business reasons was really in the consumer's interest. See, e.g., Jefferson Parish Hosp. Dist. No. 2 v. Hyde, 104 S. Ct. 1551, 1554 (1984); Arizona v. Maricopa County Medical Soc'y, 457 U.S. 332, 357-58, 364 (1982) (Powell, J., dissenting); Pas- 
that would have courts closely scrutinize each action of a hospital/staff joint venture would be a misapplication of the less-restrictive-alternative requirement. As it was applied in Silver, that requirement is a simple reasonableness test, not a warrant for close judicial regulation of private behavior. In Silver, the Supreme Court, expressly contemplating that the stock exchange would be allowed "breathing space" in which to carry out its statutory mandate to engage in self-regulation, imposed procedural requirements in order to ensure that the exchange's decisionmaking mechanism was structured and operated in a way that reduced the inherent threat to competition. ${ }^{190}$ Similarly, if a particular hospital can establish that its decisionmaking process is not dominated by competitors of those affected by the decisions being made, it should be entitled as a legitimate business entity to operate under only limited judicial oversight. The legitimacy that the stock exchange in Silver derived from its statutory mandate seems no greater than the legitimacy that a properly structured hospital/physician joint venture should enjoy by virtue of its procompetitiveness and accountability to consumers in the marketplace. ${ }^{191}$

As has been seen, the less-restrictive-alternative principle as embodied in the essential-facilities doctrine is appropriately applied to ensure that the doctors are taught their place within the larger hospital enterprise. Arguably, one might carry that principle further and say that, because the hospital could have acted purely unilaterally and dispensed with a self-governing medical staff altogether, it must accept close scrutiny by courts seeking to avert hazards to competition that the hospital voluntarily created. But that would be a very hard doctrine indeed and could be arrived at only by an unrealistic balancing of the procompetitive and anticompetitive features of the joint venture. Not only is an organized medical staff an extremely common and apparently useful managerial device, ${ }^{192}$ but it is not so inherently dangerous to competition that

chall v. Kansas City Star, 441 F. Supp. 349, 359-63 (W.D. Miss. 1977), rev'd, 605 F.2d 403 (8th Cir. 1978). A sounder approach would be to encourage stiff competition and leave such judgments to the marketplace.

190. See supra text accompanying notes $160-71$.

191. The Court in Silver acknowledged that a justification for a restraint might be derived from another federal statute "or otherwise." 373 U.S. at 348-49. See supra note 115, which observes the importance of an enterprise's legitimacy in defining the scope of judicial inquiry in a restraint-oftrade case.

192. Although the widespread use of self-governing staffs may be attributable to accreditation requirements, see supra text accompanying notes $39-40$, the device has many virtues from a management perspective. Professional work ean only be supervised by other professionals and is often best carried on under conditions of relative autonomy. See, e.g., E. FrEIDSON, DoctORING TOGETHER: A STUdY OF Professional Social Control (1975); Harris, supra note 29, at 96-98; Majone, supra note 33 , at $641-46,656-57$. Thus, a hospital organized on these lines would not only be 
courts must exercise maximum vigilance whenever it is employed. An antitrust rule that recognizes the existence of the hospital/staff combination and exposes its actions to limited scrutiny would seem to be an appropriately measured response to such hazards as exist. The tests suggested above for invoking the essential-facilities doctrine should enable courts to recognize those cases which present a truly significant danger to competition. ${ }^{193}$

2. Legal Standards for Reviewing Hospital Actions. In cases in which a conscientious hospital board and the institution's organized medical staff have acted together in limiting access to an essential facility, an allegation that they combined or conspired should not trigger the same demanding requirements and close judicial scrutiny that are called for in cases in which the physicians effectively act alone. In many cases of the former type, despite the difficulty of overcoming the allegation of conspiracy and proving the purity of motives, the court should be able to grant summary judgment in favor of the hospital prior to exhaustive discovery or a full trial. The validity of the joint venture itself remains the basic issue. Although the individual acts of a valid joint venture may still be challenged, the rigor of the requirements and the degree of scrutiny imposed at that stage must refiect the basic presumption of legitimacy that results from the court's validation of the venture's procompetitive purpose and basic structure. ${ }^{194}$

attractive to physicians but might find that a collegial form of organization is the most conducive to cooperation and high levels of achievement. The model might work better in some circumstances than in others, however. For example, institutions dealing with physicians who lack the highest professional skilis or standards might prefer a form of organization allowing for more direct control. See supra note 155 for the argument that JCAH compulsion to adopt a particular configuration may weaken the presumption of regularity which that configuration might otherwise enjoy.

193. Antitrust rules are appropriately designed with an eye to the practical ability of courts to recognize abuses where they are present in fact. See Northern Pac. Ry. v. United States, 356 U.S. 1, 5 (1958); see also supra note 121.

194. Although antitrust courts have not been accustomed to speaking of close versus limited (or minimal) scrutiny-concepts which are quite familiar and instrumental in constitutional law-, they have in fact varied the scope of their inquiry in proportion to their perception of the procompetitiveness of particular joint activity. See Havighurst \& King, supra note 57, at 164-84 (discussing professional accrediting and credentialing activities and noting how both common-law and antitrust courts, detecting a plausible reason for an action taken, have denied plaintiffs the chance to prove that another reason was actually controlling). But see Kreuzer v. American Academy of Periodontologists, 735 F.2d 1479, 1492-96 (D.C. Cir. 1984) (reversing summary judgment for defendant; requiring a finding of no less restrictive alternative to improve patient care, even given a prior finding of no anticompetitive intent).

A recent Supreme Court decision involving the antitrust state-action doctrine recognizes the need to spare professionals engaged in useful joint activity from having to face close scrutiny in an antitrust court. In Hoover v. Ronwin, 104 S. Ct. 1989, 2002 n.34 (1984), a four-justice majority limited the right of a disappointed applicant for admission to the bar to sue the private attorneys appointed as bar examiners by a state supreme court: "[Plaintiff's] claim is that the grading formula 
a. Procedural requirements. A common assumption is that antitrust law generally binds hospitals to accord "due process" to all applicants for privileges. ${ }^{195}$ This conclusion, however, reflects a misreading of the Silver case and is technically wrong. The point can be made most clearly by asking whether it would really be an antitrust violation for a hospital, acting independently though arguably in concert with its medical staff, to reject a truly incompetent, dangerous doctor without holding a hearing in his case. Another way of raising the question is to ask whether the Federal Trade Commission could, without alleging a substantive abuse, sue a hospital for not maintaining fair procedures. Although liability in Silver was automatic once faulty procedures were found, ${ }^{196}$ it does not follow from that result that a hospital, as distinct from its medical staff acting alone, is similarly obligated to be fair to every applicant for privileges. If the role of the applicant's physician competitors has been limited enough to make the essential-facilities doctrine inapplicable, the danger of anticompetitive abuse is much less than that which prompted the Silver Court to insist on fair procedures as a less restrictive alternative. Thus, it seems probable that a hospital which had good reasons for summarily rejecting a plaintiff's application for privileges would not be denied an opportunity to present those reasons to the court. ${ }^{197}$

Although a hospital is not absolutely required under antitrust law to accord procedural due process to applicants for admitting privileges, this is not to say that due process would not be a good idea. Not only might such a policy be required by a state statute or common-law rule ${ }^{198}$ or by hospital accreditors, ${ }^{199}$ but by-laws guaranteeing due process might, by increasing job security and the prevailing sense of professionalism, make

was devised for the purpose of limiting competition. If such an allegation is sufficient to survive a motion to dismiss, examining boards and committees would have to bear the substantial "discovery and litigation' burden attendant particularly upon refuting a charge of improper motive." Although the minority responded at some length to these concerns, id. at 2010-13, by expressing confidence in the law's "procedures for speedily disposing of unfounded claims," the need for some protection in privileges cases seems clear. See supra note 158 and infra text accompanying notes 215-24. For other indications of the increasing recognition of the importance of not inhibiting useful joint activity, see infra note 216 .

195. E.g., Dolan \& Ralston, supra note 19, at 724-28; Drexel, supra note 19, at 227, 232; Kissam \& Webber, supra note 13, at 648-51; see also Havighurst \& King, supra note 57, at 179.

196. See supra text accompanying notes 160-71.

197. As a general proposition, a denial of procedural protections can never be an antitrust violation in itself because it cannot, in the absence of a substantive abuse, cause harm to competition. The seeming exception to this proposition in a case where a medical staff sits in final judgment, see supra text accompanying notes $160-71$, simply reflects the substantive illegality of an arrangement whereby physicians collectively assume unnecessarily broad powers to disadvantage their competitors.

198. See supra notes $83-94$ and accompanying text.

199. See 1984 MANUAL, supra note 8 , at $91-95$, for procedural requirements of accreditation. 
a hospital more attractive to physicians. ${ }^{200}$ Moreover, fair and open pro- cedures would help to demonstrate in any antitrust case that the hospital and its medical staff were jointly committed to evenhanded application of objective criteria. Finally, an available hearing record would aid the hospital board in exercising its independent judgment on each personnel decision; indeed, the absence of procedures facilitating effective oversight of staff actions might suggest that the hospital had abdicated its decisionmaking function in favor of the medical staff, with the legal consequences developed earlier. ${ }^{201}$ It thus appears that antitrust law provides strong incentives for hospitals to be fair to those who wish to use the facility. But fairness as such is only a desirable by-product, not a primary concern, of antitrust doctrine. ${ }^{202}$

b. A rational-basis test for substantive actions. The proper substantive test for reviewing collaborative actions by a hospital and its medical staff would appear to be a rational-basis test, under which the decision would be upheld upon demonstration of some plausible ground related to a legitimate interest of the hospital. ${ }^{203}$ Thus, summary judgment or a directed verdict would be appropriate if documentary evidence and affidavits showed that the hospital's action reflected its corporate concerns about such things as its business policies and reputation, ${ }^{204}$ the quality of care provided, ${ }^{205}$ its exposure to malpractice suits, ${ }^{206}$ its effi-

200. See supra note 192.

201. In the Silver case, fair procedures were required in part because the actions of the stock exchange were not subject to review by a public agency and because such procedures would facilitate review by an antitrust court. 373 U.S. at $364-66$. Here, review by the hospital board obviates the absolute necessity for fair procedures. Nevertheless, their use would strengthen the hospital's claim that it acted independently in a particular case.

202. See supra note 113 .

203. For a parallel argument and similar conclusion concerning the test applicable to denials of valuable accreditation or certification, see Havighurst \& King, supra note 57, at 169-201 (discussed infra in text accompanying note 276).

204. See, e.g., Robinson v. Magovern, 521 F. Supp. 842, 859-60, 870, 873 (W.D. Pa. 1981) (hospital sought to establish a reputation in teaching and research, in which applicant had little interest); see also Stone v. William Beaumont Hosp., 1983-2 Trade Cas. (CCH) \ 65,681, at 69,477-78, 69,484 (E.D. Mich. 1983) (rejected doctor was incompatible with hospital's growth strategy).

205. See, e.g., Smith v. Northern Mich. Hosps., 703 F.2d 942, 952-53 (6th Cir. 1983) (exclusive contract for emergency room physicians, which limited plaintiff doctors' practices, was justified by quality-of-care concerns); Pontius v. Children's Hosp., 552 F. Supp. 1352, 1358-60 (W.D. Pa. 1982) (hospital board affirmed a medical staff recommendation that plaintiff's privilege be revoked for incompetency).

206. Aside from basic quality-of-care concerns, a hospital might fear liability for retaining physicians who had been let go elsewhere. See infra notes 228-30 and accompanying text. Another seemingly valid business concern might be that a physician's criticism of nurses or colleagues might inspire patients to sue. See, e.g., McElhinney v. Medical Protective Co., 549 F. Supp. 121, 125 (E.D. Ky. 1982), remanded for dismissal on jurisdictional grounds, No. 82-5636, unpublished slip op. (6th Cir. June 5,1984$)$. One wonders, however, how many hospitals would advance such a justification. 
cient and profitable operation, ${ }^{207}$ and the maintenance of harmonious relationships within the institution. ${ }^{208}$ Under this test, a court would not concern itself, as it would if the essential-facilities doctrine applied,209 with whether the ostensible motives for the actions taken were the real motives or whether the adverse effect of the hospital action on competition among practitioners was outweighed by its actual contribution to fulfilling the hospital's objectives.

Some cases will involve decisions by hospital boards in concurrence with their medical staffs that courts may find particularly difficult to dismiss summarily on the basis of evidence that the action had a rational relationship to the hospital's normal business objectives. One category of such cases would be those in which the hospital appears to be furthering some anticompetitive purpose of its own. The clearest example would be a case in which a hospital had refused admitting privileges to physicians associated with a fledgling HMO, perhaps in the hope that, without hospital access, the HMO would disappear both as a competitor and as a cost-conscious purchaser of hospital services. ${ }^{210}$ A plaintiff in such a case would undoubtedly charge the hospital with making common cause with its medical staff, whose members would probably also desire the HMO's extinction.

In such a case, whether or not a hospital/physician conspiracy against the HMO exists should not change the likelihood of antitrust relief against the hospital. Section 2 of the Sherman Act provides tools for checking unilateral monopolizing conduct and allows close scrutiny of the hospital's motives to determine whether the conduct in question was inspired by a monopolistic intent.211 Although section 2 also prohib-

207. See supra text accompanying notes $219 \& 226$.

208. On personality-related disputes, see supra note 126.

209. See supra text accompanying notes 171-73.

210. Though having no hospital of its own, an HMO is properly viewed as a competitor of the hospital itself because it frequently substitutes outpatient for inpatient services. See Manning, Leibo. witz, Goldberg, Rogers \& Newhouse, A Controlled Trial of the Effect of a Prepaid Group Practice on Use of Services, 310 NEw ENG. J. MED. 1505, 1507 (1984) (prepaid group practice leads to 40 percent fewer admissions than under fee-for-service plans). Moreover, the HMO may be feared because it is likely to become a hard, price-conscious bargainer with the hospital. For cases involving antitrust challenges to anti-HMO activities by hospital physicians, see Ohio ex rel. Brown v. Mahoning County Medical Soc'y, 1982-1 Trade Cas. (CCH) \ 64,557 (N.D. Ohio 1982); United States v. Halifax Hosp. Medical Center, 1981-1 Trade Cas. (CCH) \ 64,151 (M.D. Fla. 1981); Williams v. Kleaveland, 534 F. Supp. 912, 915 (W.D. Mich. 1981); Forbes Health Sys. Medical Staff, [1979-83 Transfer Binder] TRADE REG. REP. (CCH) I 21,656 (Oct. 15, 1979) (FTC consent order).

211. Under section 2, the hospital's refusal to deal with physicians who associate with its HMO competitor is properly analyzed as a unilateral attempt to monopolize the care of patients for whom hospitalization is an option. See supra note 210; $f f$. Lorain Jourual v. United States, 342 U.S. 143, $149-50$ (1951) (near-monopolist's refusal to deal with those patronizing a competitor). This theory would not be available if the presence of other hospitals in the community eliminated the requisite dangerous probability that a monopoly might be achieved. On the latter requirement, see, for exam- 
its conspiracies to monopolize, an allegation of such a conspiracy should - have no more effect on the legal test applied to the conduct in question than an allegation of a section 1 conspiracy. ${ }^{212}$ For reasons indicated above, joint action by a hospital and its medical staff should be judged under a rule that limits scrutiny of the joint venture's day-to-day business decisions. Adoption of this way of assessing the conduct of a legitimate joint venture would leave ample room for finding unlawful monopolization or an unlawful attempt to monopolize in an appropriate case. ${ }^{213}$ Whether concerted or unilateral, the conduct in such cases should be scrutinized in the same way for direct exclusionary effects on the hospital's HMO competitor.

Another category of cases in which a court might be tempted to subject a hospital's independent conduct to close rather than limited scrutiny would be that in which the hospital could be suspected of acting not strictly in its own interest but as a "cat's paw"214 for its doctors in suppressing competition that the latter find objectionable. Members of the governing board of a community hospital might, for example, be discovered-if depositions were permitted-to hold the view that the hospital's or the community's interest is best served by going along with the medical staff in borderline cases even at some cost to the hospital itself. Although this possibility exists, it seems wiser to ignore it or, alternatively, not to treat such a hospital policy, even if it could be established in a particular case, as a Sherman Act violation. The clearest abusesthose involving systematic abdication by the hospital-would be captured through the application of the essential-facilities doctrine as suggested above. Furthermore, the changing economic environment is gradually narrowing the discretion of hospitals to subordinate their own interests to those of their physicians. In general, it seems appropriate to presume that hospitals that act independently in privileges matters do so

ple, United States v. Empire Gas Corp., 537 F.2d 296, 305-07 (8th Cir. 1976), cert. denied, 429 U.S. 1122 (1977); NATIONAL COMMISSION FOR THE REVIEW OF ANTITRUST LAWS AND PROCEDURES, REPORT TO THE PRESIDENT AND ATTORNEY GENERAL 146-48 (1979). In the event of such conscious parallelism, however, a successful conspiracy case might be built against the several hospitals if they all refused to compete for the HMO's paying patients. See infra notes 229-30 and accompanying text. In the absence of evidence to support either of these theories, however, the allegation of a hospital/physician conspiracy should not alter the result.

212. A conspiracy to monopolize is an independent offense not requiring proof of probable success in monopolization. United States v. Chas. Pfizer \& Co., 245 F. Supp. 737, 738-39 (E.D.N.Y. 1965). Nevertheless, if the alleged concerted action is in fact procompetitive, it lacks the quality that makes it separately actionable.

213. See supra note 210 and cases cited therein.

214. This suggestive term was used by Judge Posner in an analogous context in Valley Liquors, Inc, v. Renfield Importers, Ltd., 678 F.2d 742, 743 (7th Cir. 1982). The idea that a hospital might support its physician's anticompetitive efforts, perhaps under collective pressure, appears in several privileges cases. E.g., Robinson v. Magovern, 521 F. Supp. 842, 907 (W.D. Pa. 1981). 
in their own or the community's interest-as they see those interests ${ }^{215}$ and that antitrust courts cannot improve upon hospital decisions provided that they bear a rational relationship to the hospital's business purposes. Even if an occasional abuse should go unpunished under this rule, the public would be better off than under a rule exposing all hospital/ physician collaboration to close scrutiny-as the following discussion seeks to show more fully.

\section{Policy Considerations.}

The antitrust rules suggested above, by being more favorable to actions taken by a hospital in conjunction with its medical staff than to actions by the medical staff alone, would appear to create incentives that are desirable from a policy standpoint. In particular, such rules would inspire hospitals to assume decisionmaking responsibilities that some of them have allowed to devolve without appreciable accountability upon their physicians. Although external pressures are currently inducing hospitals to assert their interests more strongly at the expense of physicians, in some institutions these pressures may not be sufficient to change old patterns of deference to the medical staff. In the current climate, it would be helpful if courts would underscore the principle that hospitals, as independent entities accountable to consumers in the ultimate marketplace, are deemed to be more reliable decisionmakers on staffing questions than are powerful organizations of physician competitors.

Perhaps the best policy argument for the suggested legal rules is the benefit that consumers would derive from the changes in hospital behavior that these rules would permit. A rule that exposed all hospital personnel actions to the same close scrutiny without regard to whether they were predominantly vertical or horizontal in character would inhibit aggressive hospital efforts to ensure the quality of care and to obtain physician cooperation in cost-containment efforts. Because undergoing such scrutiny entails high legal costs, a hospital considering whether to appoint or retain a borderline candidate would have to weigh not only the risk of liability but also the risk of being sued and having to defend its action. ${ }^{216}$ Moreover, a hospital would have to bear the substantial costs

215. This presumption seems sounder than those suggested by FTC official Winslow, supra note 117, discussed supra note 147.

216. The appropriateness of developing antitrust rules with a view to their effects on desirable activities seems clear. See supra notes 115, 121 \& 194. In Hoover v. Ronwin, 104 S. Ct. 1989 (1984), the Supreme Court said, "[t]here can be no question that the threat of being sued for [treble] dam. ages-particularly where the issue turns on subjective intent or motive-will deter 'able citizcns' from performing this essential public service [as bar examiners]." 104 S. Ct. at 2002, n.34. The dissenting opinion of Justice Stevens, although rejecting the majority's extension of the statc-action doctrine to protect against litigation burdens, see supra note 194, did not appear to suggest that 
of proceeding internally in every case in such a way-with lengthy hearings and appeals-that its action could withstand strict legal scrutiny. Thus, a rule that did not explicitly reduce the procedural requirements and the scope of judicial review applicable to a hospital's business decisions would perpetuate an excessive incentive for hospitals to tolerate questionable performance. ${ }^{217} \mathrm{~A}$ court should be impressed by the threat to patients' health and safety that would result from an antitrust rule that inhibited hospital efforts to improve its overall performance. ${ }^{218}$ In addition, it should recognize the impediment to hospital cost-containment efforts that would result if a doctor whose exclusion was sought solely because of overspending on patient care were entitled to a full judicial hearing. ${ }^{219}$

It is no answer to these arguments against close scrutiny to say that courts, in their detailed appraisals under the rule of reason, would recognize the legitimacy of the hospital's business interests and would ultimately defer to hospital actions. ${ }^{220}$ As already noted, hospitals facing close scrutiny, even under a deferential standard of review, would still have reason to fear costly litigation and would curb their quality-assur-

antitrust rules should never be formulated with an eye to limiting private persons' exposure to harassing lawsuits that inhibit desirable behavior. Indeed, the Court has been quite attentive to such concerns in antitrust cases, most recently and forcefully in Monsanto Co. v. Spray-Rite Serv. Corp., 104 S. Ct. 1464, 1470 (1984) (rejecting a standard of proof unfavorable to the defendant because it "could deter or penalize perfectly legitimate conduct"). See also Continental T.V., Inc. v. GTE Sylvania, Inc., 433 U.S. 36, 57 (1977) (territorial resale restrictions subject to rule of reason); Barry Wright Corp. v. ITT Grinnell Corp., 724 F.2d 227, 234 (1st Cir. 1983) (expressing concern that antitrust laws not be read so as to chill legitimate price competition).

217. The Court's recognition in Silver of the need for "breathing space" to permit effective selfregulation, see supra note 162 and accompanying text, confirms the relevance of these considerations in shaping legal principles.

218. Indeed, the implications of hospital decisions for the quality of medical care is a striking feature of these eases-one that should induce courts to pay more than the customary amount of attention to efficiency concerns. See supra note 113. In vertical restraint cases, courts have generally not perceived non-health-related efficiency claims to be important enough to weigh heavily in favor of allowing a manufacturer discretion in choosing his distributors. See infra text accompanying notes 238-80. For a case in which a safety-related issue caught a court's attention, see Tripoli Co. v. Wella Corp., 425 F.2d 932, 937-38 (3d Cir.) (resale restriction on potentially dangerous product upheld), cert. denied, 400 U.S. 831 (1970).

219. Increasing price competition among hospitals and the new Medicare policy of paying hospitals prospectively determined prices, see supra text accompanying notes 14-15, are being counted upon to generate efficient spending, but this expectation assumes that hospitals will be able to exert some control over physicians and their spending practices. See P. Joskow, supra note 29, at 36-39; Harris, supra note 29 , at $86-93$. Ultimately, hospitals must have some freedom to limit or revoke the admitting privileges of undeniably competent physicians who, perhaps out of a conscientious concern for the welfare of their patients, are uncooperative about cost control. Courts that have been willing to accept hospitals' quality-related decisions are likely to be sympathetic toward the physician plaintiff in a case where quality is not the issue. But sound policy suggests that hospital business judgments taken in good faith should be accepted for better or for worse.

220. See supra note 160 . 
ance and cost-containment efforts accordingly. Moreover, as long as hospital and staff decisions are treated alike, any deference shown to the resulting actions would be quickly interpreted as deference to the professionalism of the physician decisionmakers. ${ }^{221}$ Without a rule that directly addresses the heightened threat to competition that exists when physicians dominate the decisionmaking process, a deferential stance by the courts would leave unpenalized many actions that are in fact inspired by physician self-interest. For these reasons, the rules recommended herein, which expressly limit judicial scrutiny of decisions in which the hospital participates as an independent entity standing in a vertical relationship to the market in which competition is affected, offer a sounder approach to staff privileges disputes than a policy of general deference to all privileges decisions.

Another reason for focusing antitrust law primarily on purely horizontal restraints is the need to escape the mistaken but durable notion that antitrust cases involving privileges disputes are primarily concerned with ensuring fairness to individual competitors. ${ }^{222}$ As long as actions in which the hospital actively participates are treated as indistinguishable from collective actions by a candidate's competitors, the perception will persist that the antitrust issue in these cases is simply whether the hospital, a large and powerful enterprise, dealt fairly with a mere individual seeking to enter or stay in the market. Antitrust law has frequently been invoked by health care practitioners who feel unfairly treated by powerful market intermediaries, and courts have so far not succeeded in making clear that the law is concerned only with preserving the integrity of the competitive process and not with regulating the terms of dealing between vertically related parties. As argued more fully below, ${ }^{223}$ the courts have an obligation to strengthen, not weaken, the various middlemen in health care markets who have the capacity to act as knowledgeable agents for consumers in selecting health care practitioners and in structuring efficient delivery mechanisms.

Finally, the wisdom of the legal analysis offered here is confirmed by the simple fairness of penalizing only conduct that was readily avoidable by the defendants and of sheltering normal business activity from undue litigation risks and burdens. The Sherman Act is, after all, a criminal statute carrying punitive remedies even in a civil case. It should therefore not be interpreted, without good reason, to impose the same burden of proof and risk of liability on an institution whether or not it has acted

221. Earlier discussion, supra text accompanying notes $95-102$, indicated why the matter should be approached otherwise.

222. See supra text accompanying notes $111-13$ \& 195-202.

223. See infra text accompanying notes $263-80$. 
affirmatively to curb physician dominance in institutional decisionmaking. Similarly, individual physicians participating in the useful work of a medical staff ought not to be exposed to an undue and unavoidable risk of being sued by individuals who are offended by their efforts. ${ }^{224} \mathrm{~A}$ rule distinguishing between joint hospital/physician actions and actions effectively controlled by the medical staff would go far toward protecting both responsible hospitals and the physicians who aid them while submitting to their authority. The analysis herein would ensure that the essentialfacilities doctrine and close judicial scrutiny are invoked only against conduct that is avoidable by the parties and only against purely horizontal combinations of competitors.

\section{Antrtrust Rules In Action-A Hypothetical CASE}

The effect of an antitrust rule limiting judicial scrutiny of hospital staffing decisions when they appear not to have been made by the medical staff can be appreciated more fully by considering a hypothetical case. Assume that Dr. $X$ has had his privileges at each of the three hospitals in his community revoked because of his allegedly disruptive personality. Cases of this kind are apparently common and present some troublesome possibilities. ${ }^{225}$ It is the task of courts to uncover the abuses without preempting or inhibiting legitimate private decisionmaking.

The first question is whether Dr. $X$ can make out an antitrust case against any of the hospitals. Under the rule proposed above, a court should be more easily satisfied if it finds that the hospital acted, if not unilaterally, at least as an independent participant in the decision to terminate Dr. $X$. The following questions would be relevant in determining whether the hospital had simply acceded to the medical staff's judgment:

(1) Did the hospital's decisionmaking process demonstrate its independence?

(2) Were the procedures followed by the medical staff such that the board was able to review the decision effectively on its merits?

(3) Did the board recognize the possibility of bias on the part of the staff decisionmakers and attempt to ensure that it was receiving sound advice?

(4) Did the medical staff offer good professional reasons of a kind that the hospital might regard as valid?

(5) Did the hospital board seek to verify those reasons? Did it, for example, seek outside advice or make inquiry of key witnesses under circumstances ensuring that their testimony was not coerced?

(6) Did the board consider any countervailing factors? For example, if Dr. $X$ 's patients represented an actual or potential quarter mil- 
lion dollars of hospital revenues each year, did the hospital board consider that fact?226

(7) Does it appear from the record, or was it plausible, that the board judged $\operatorname{Dr} . X$ to be enough of a problem to warrant giving up the revenue he represented?

The hardest case would be presented if it appeared that the hospital, although acting independently, had sacrificed Dr. $X$ in pursuance of a policy of deferring to staff preferences on close questions. Because such hospital motives could seldom be ruled out without a full and costly inquiry, the court should declare that, because the alleged conspiracy occurred within a single, properly structured joint enterprise, close scrutiny of the action taken against Dr. $X$ would be inappropriate. Because, under limited scrutiny, a court could find a sufficient business reason for the hospital to terminate $\operatorname{Dr} . X$, the case should come to an early end if the court reaches satisfactory conclusions on the foregoing questions.

If the independence of any of the hospitals could not be established, the court should proceed to evaluate the underlying motives of the medical staff. Such an inquiry would usually require a full trial. The ultimate question would remain whether, judged in depth, the staff's action was the result of a business decision made in the interest of the hospital. Although the decided privileges cases generally have taken this approach, the courts' failure to identify the actual locus of decisionmaking in the hospital may have caused them to demand too much of responsible hospitals and to be insufficiently skeptical toward decisions dominated by medical staffs. ${ }^{227}$ Given the availability of a less restrictive alternative way of operating a hospital, there is no reason to be deferential toward physicians who have assumed dangerous and unchecked powers.

In Dr. $X$ 's case, it might be thought that the concurrence of the other hospitals supported the result at each institution. ${ }^{228}$ Another and more ominous possibility, however, is that there was a community-wide hospital or hospital/physician boycott aimed at $\operatorname{Dr} . X$. This possibility

226. Lest it be thought that a crass tradeoff between profits and quality would be unseemly, it should be observed that the money generated by Dr. $X$ could be used to improve the quality of the hospital in other ways. For description of an extraordinary unreported California case in which a hospital board, seeking to fill beds, overrode its medical staff, appointed a controversial physician, and was sued (unsuccessfully) by the staff, see Carlova, Is This a Waterloo in the Privileges War?, MED. ECoN. Jan. 7, 1985, at 62.

227. See supra note 146 and accompanying text.

228. One must avoid the trap of thinking it natural that the same standard of acceptability should govern at each hospital. Competitive principles contemplate the possibility, which is frequently confirmed in reality, that competing decisionmakers will maintain different standards and may reach different judgments even on the same evidence. Even though a hospital can be accused of negligence in permitting a physician with a questionable history to practice, its legal obligation is only to exercise responsible oversight and judgment. See supra note 22-26 and accompanying text. As noted in the text, the antitrust laws require that its judgment be exercised independently. 
should be taken seriously because some medical communities have been - accustomed to operate in just such a way, assuming essentially regulatory power over who can practice in the area. Although the existence of a larger conspiracy would probably have to be proved circumstantially, it is quite likely that Dr. $X$ would be able to show, as one element of his proof, that there was a great deal of communication between the members of the respective medical staffs. The inference of conspiracy would be further supported if one or more hospitals had departed from its regular schedule for reviewing Dr. $X$ 's status; unless Dr. $X$ 's actions precipitated a true emergency, this unusual coordination of action would permit a trier of fact to find collusion based on the likelihood that each hospital, fearful of losing to others the patient revenue generated by $\operatorname{Dr} . X$, was hesitant to act unless its competitors did. Antitrust law has well-developed theories for analyzing such "conscious parallelism" and would permit a judge or jury to find a hospital boycott on this evidence.229 Although the hospitals could probably offer colorable reasons-such as malpractice fears and quality concerns-why each might have acted without regard to what their competitors did, the appearance of "plus factors" indicative of interdependent decisionmaking could justify a finding of conspiracy. ${ }^{230}$ Given the high risk that hospital actions would be coordinated in such cases, courts should not be too easily persuaded by the business reasons offered in support of the claim that each hospital would have acted as it did even in the absence of parallel action by the others.

If a true boycott were found, it should certainly be treated as a per se violation, so that there could be no defense predicated on the notion that eliminating Dr. $X$ was a service to the community. Although a few courts have hesitated to apply the per se rule to true boycotts by health care providers, ${ }^{231}$ the situation here would deserve no such leniency. Under basic antitrust precepts, Dr. $X$ is entitled to the benefit of truly independent hospital decisions regarding his qualifications and desirability. Although it can be highly beneficial and procompetitive for competitors to share information and even to offer their opinions concerning the

229. See generally Theatre Enterprises v. Paramount Film Distrib. Corp., 346 U.S. 537, 541-42 (1954); Interstate Circuit v. United States, 306 U.S. 208, 226-27 (1939); Bogosian v. Gulf Oil Corp., 561 F.2d 434, $445-47$ (3d Cir. 1977), cert. denied, 434 U.S. 1086 (1978); Posner, Oligopoly and the Antitrust Laws: A Suggested Approach, 21 STAN. L. REv. 1562, 1576-78 (1969); Turner, The Definition of Agreement Under the Sherman Act: Conscious Parallelism and Refusals to Deal, 75 HARV. L. REV. 655 passim (1962).

230. See P. Areeda, Antitrust Analysis 371-82 (3d ed. 1981).

231. See supra note 101 and notes 103-14 and accompanying text; see also Everhart v. Jane C. Stormont Hosp., 1982-1 Trade Cas. (CCH) \ 64,703 (D. Kan. 1982) (alleged boycott of physician by two hospitals held inappropriate for treatment under per se rule; distinction from action by a single hospital not observed). 
qualifications of their competitors, in no event should sellers or buyers acting in concert finally judge competing sellers. ${ }^{232}$ In health care markets, hospitals clearly need information and professional help in judging physicians, but the antitrust laws are appropriately invoked to ensure that, in the final analysis, the individual hospitals themselves make the final decisions.

\section{IMPLICATIONS FOR THE JURISDICTIONAL REQUIREMENT OF AN EFFECT ON INTERSTATE COMMERCE}

Most plaintiffs challenging privileges decisions under the Sherman Act have encountered as a major hurdle the jurisdictional requirement that confines the reach of the federal antitrust laws to conduct having some effect on interstate commerce. ${ }^{233}$ Although it has usually proved surmountable, a few courts have used the jurisdictional requirement to avoid immersion in disputes that, although exceedingly complex, seemed trivial from the standpoint of the larger public interest. ${ }^{234}$ The foregoing substantive analysis of the law applicable to privileges cases provides rather clear guidance to the resolution of the jurisdictional issue.

Essentially, there are two views concerning how the interstate commerce requirement should apply in privileges cases. Some courts have looked only for some indication that the hospital itself was engaged in commerce and have found jurisdiction on the basis of the total volume of supplies and financing fiowing to and through the hospital from interstate channels. ${ }^{235}$ The more common and more demanding view requires

232. See supra notes 107-12 and accompanying text.

233. The greatly increased volume of antitrust litigation involving the health care industry and other professions in recent years is attributable not so much to the Supreme Court's 1975 decision that the learned professions are not exempt from the antitrust laws, Goldfarb v. Virginia State Bar, 421 U.S. 773, 786-89 (1975), as to the new and more liberal jurisdictional tests appearing in Goldfarb, 421 U.S. at 783-86, and other cases, e.g., Hospital Building Co. v. Trustees of Rex Hosp., 425 U.S. 738, 745-46 (1976) (potential loss of revenue to plaintiff hospital's out-of-state suppliers, managers, and financiers held a sufficient allegation of "substantial effect" on interstate commerce); McLain v. Real Estate Bd., 444 U.S. 232, 242-43 (1980) (particularized showing of effect on interstate commerce not required). By lowering the threshold requirement to show connection between the challenged conduct and interstate commerce, these cases made federal antitrust policy for the first time an immediate concern of local professionals and hospitals. Staff privileges cases, often involving a single professional's practice at a single hospital, have been the most difficult to resolve under the new tests. See generally Note, Sherman Act Jurisdiction in Hospital Staff Exclusion Cases, 132 U. PA. L. Rev. 121 (1983).

234. See, e.g., McElhinney v. Medical Protective Co., No. 82-5636 (6th Cir. June 5, 1984) (unpublished slip op. available Dec. 31, 1984 on LEXIS, Genfed library, Cir file), remanding for dismissal on jurisdictional grounds, 549 F. Supp. 121 (E.D. Ky. 1982); Furlong v. Long Island College Hosp., 710 F.2d 922, 926-28 (2d Cir. 1983); Cardio-Medical Assocs. v. Crozer-Chester Medical Center, 536 F. Supp. 1065, 1080-84 (E.D. Pa. 1982), rev'd, 721 F.2d 68 (3d Cir. 1983).

235. E.g., Cardio-Medical Assocs. v. Crozer-Chester Medical Center, 721 F.2d 68, 76 (3d Cir. 1983); Miller v. Indiana Hosp., 562 F. Supp. 1259, 1284-85 (W.D. Pa. 1983); Feldman v. Jackson 
that the specific hospital action challenged by the plaintiff be shown to have some significance for the flow of interstate trade. ${ }^{236}$ In addition to allowing courts to dismiss complex cases that seem to be only localized private disputes not appropriate for resolution in a federal court, this latter rationale seems consistent with the notion that the antitrust laws should be concerned with the fate of competition, not of individual competitors. It may easily be doubted, for both jurisdictional and substantive antitrust purposes, that the exclusion of a single doctor or other practitioner from a single hospital has any significant bearing on consumer welfare, the essential concern of federal antitrust law.

Despite the plausibility of the more demanding view of the jurisdictional requirement in privileges cases, the analysis presented above should point toward adcption of the more liberal position. The focus in that analysis on decisionmaking processes in individual hospitals suggests that the relationships to be examined substantively in each case are likely to have repercussions transcending the harm to any particular plaintiff. The history of physician domination of hospital decisionmaking, the findings of economists that indicate strong physician influence over hospital managers, and the likelihood that hospital/physician relationships were structured in response to JCAH standards reflecting physician preferences, all point to the need for antitrust oversight of hospital decisionmaking mechanisms. Courts should therefore recognize that privileges cases involve more than the public's stake in preserving an individual plaintiff as a competitor. ${ }^{237}$ Precisely because the law focuses primarily on protecting competition, not competitors, an important issue in each privileges case is whether hospital/physician relationships within the particular hospital preserve the integrity and vertical character of hospital personnel decisions that are so vital to the functioning of a competitive market for health manpower. Once judges recognize what con-

Memorial Hosp., 509 F. Supp. 815, 820 (S.D. Fla. 1981); see also McDonald v. Saint Joseph's Hosp., 524 F. Supp. 122, 129 (N.D. Ga. 1981) (identifying the two tests but choosing neither); $c f$. Western Waste Serv. Sys. v. Universal Waste Control, 616 F.2d 1094, 1096-97 (9th Cir.) (attempt to monopolize trash pickup service), cert. denied, 449 U.S. 869 (1980).

236. E.g., Furlong v. Long 1sland College Hosp., 710 F.2d 922, 926 (2d Cir. 1983); Mishler v. St. Anthony's Hosp. Sys. 694 F.2d 1225, 1227-28 (10th Cir. 1981); Crane v. Intermountain Health Care, 637 F.2d 715, 723-24 (10th Cir. 1980); Carey v. Daniel Freeman Memorial Hosp., 1984-1 Trade Cas. (CCH) ๆ 65,831, at 67,475 (C.D. Cal. 1983); Pao v. Holy Redeemer Hosp., 547 F. Supp. 484, 489 (E.D. Pa. 1982); Malini v. Singleton \& Assocs., 516 F. Supp. 440, 442 (S.D. Tex. 1981); $c f$. Nurse Midwifery Assocs. v. Hibbett, 577 F. Supp. 1273, 1276-77 (M.D. Tenn. 1983) (requiring an allegation of nexus in order to avoid presuming an effect on commerce).

237. See Cardio-Medical Assocs. v. Crozer-Chester Medical Center, 721 F.2d 68, 75 (3d Cir. 1983) ("there is no reason why an enterprise engaged in nationwide anticompetitive conduct should not be subject to suit by a local victim simply because the defendant's conduct, as regards that particular plaintiff, does not affect interstate commerce"). 
sumers have at stake in this regard, they should have no trouble concluding that the federal interests in these cases are great and legitimate enough that the jurisdictional requirement should be deemed satisfied.

Because a hospital that maintains a proper distance from its physicians would be allowed wide discretion in staffing decisions under the analysis herein, courts employing this conception of their role should find cases easy to dismiss on the merits if no significant threat to the competitive process exists. Thus, jurisdictional barriers need not be erected to protect the courts against a flood of trivial litigation. By the same token, in view of the importance of hospital independence to the structural integrity of the market as a whole, no jurisdictional impediment should be imposed on plaintiffs who claim to have been denied their right, not to a disinterested decision, but to a self-interested hospital decision on their qualifications.

\section{ANALogies to the LAW Governing Other Vertical RESTRAINTS}

Consideration of antitrust law's past experience in evaluating vertical relationships other than those between hospitals and physicians may shake one's confidence that courts can be persuaded to adopt the perspective and legal rules recommended herein or otherwise to exercise restraint in reviewing hospital actions. In the past, courts have been quick to find pretexts for closely examining single-firm conduct that affects competition or competitors in a related market. ${ }^{238}$ These so-called vertical restraints-by which a seller ties the hands of its customers-have been subjected to legal rules that are generally confusing and poorly grounded in policy. Indeed, the propensity of courts and lawyers to view antitrust litigation as an occasion for enforcing standards of fair dealing and for vindicating the weak against the strong is most pronounced in these cases. Although the law is changing, the legal tradition from which the courts proceed is partly rooted in fairness concerns, in regulatory impulses, and in ignorance of the real limits that markets impose on the freedom of, and incentives to, sellers to engage in conduct that is not efficient and welfare-enhancing. To the extent that the dead hand of precedent and a regulatory mentality control legal thinking about privileges cases, the legal rules proposed herein, however sensible they may be in

238. Cases revealing an extreme readiness to discover the concerted action necessary to subject private conduct to scrutiny under section 1 include Albrecht v. Herald Co., 390 U.S. 145, 149 (1968), and United States v. Parke, Davis \& Co., 362 U.S. 29, 45 (1960). See generally Fulda, Individual Refusals to Deal: When Does Single-Firm Conduct Become Vertical Restraint?, 30 LAW \& Contemp. Probs. 590 (1965); Turner, supra note 229. 
policy terms, may fail to gain adherents. On the other hand, it may be that the logic demonstrated above may be useful in further discrediting the courts' handling of other kinds of vertical restraints.

\section{A. Manufacturer/Distributor Agreements.}

The propensity of antitrust courts to interfere with business discretion has been most pronounced in the law relating to restrictions placed by a manufacturer on competition in the distribution of its products. Such vertical restraints, which are most often challenged by a former dealer alleging that his termination by a manufacturer was improper, have generally been subjected to close legal scrutiny. ${ }^{239}$ Although the analogy between such cases and denials of hospital admitting privileges is not close, it needs to be examined for useful lessons not only about the law governing hospital/physician relationships but also about the law governing vertical restraints generally.

Many vertical restraint cases have been concerned with discovering whether a manufacturer had entered into per se unlawful resale-pricemaintenance agreements with its dealers; ${ }^{240}$ other cases have applied the rule of reason to vertical agreements limiting nonprice competition among distributors. ${ }^{241}$ Even though the concerns in cases of both types differ from the concerns that are prompted by denials of hospital privileges, an analogy does exist. At the most basic level, the issue in all these cases is whether an entity having a vertical relationship to another market must avoid arrangements that somehow limit competition in that market, or whether such arrangements can be seen as a manifestation of competition in the primary market and as contributing enough to the achievement of efficiency to obviate antitrust concerns. The courts' past antipathy to vertical restraints in the manufacturer/distributor situation and their solicitude for terminated dealers suggest a mindset that, if carried over into the hospital context, could make it difficult for hospitals to avoid close scrutiny of their personnel actions.

Because the law applicable to manufacturer/distributor restraints is now a controversial area, ${ }^{242}$ any recognition of an analogy between such

239. See infra note 247 and accompanying text.

240. E.g., cases cited supra note 238; Monsanto Co. v. Spray-Rite Serv. Corp., 104 S. Ct. 1464, 1469 (1984), and cases cited therein at 1468 n.5.

241. E.g., Continental T.V., Inc. v. GTE Sylvania, Inc., 433 U.S. 36, 59 (1977).

242. See, e.g., Easterbrook, Vertical Arrangements and the Rule of Reason, 53 ANTITRUST L.J. 135, 153-59 (1984) (arguing that vertical arrangements are generally procompetitive and favoring a rule of reason approach); Pitofsky, In Defense of Discounters: The No-Frills Case for a Per Se Rule Against Vertical Price Fixing, 71 GEO. L.J. 1487, $1487-89$ (1983) (favoring a per se rule of illegality); Posner, The Next Step in the Antitrust Treatment of Restricted Distribution: Per Se Legality, 48 U. CH1. L. REV. 6, 6, 22-26 (1981) (favoring a per se rule of legality). Most of the debate focuses on the 
restraints and hospitals' exclusionary staffing decisions may be counterproductive in the effort to achieve legal clarity. ${ }^{243}$ Nevertheless, several current trends in the law of vertical restraints are noteworthy as signs that courts will be less insistent in the future on promoting competition between and fairness toward distributors and be more respectful of manufacturers' decisions. First, the Supreme Court recently has reasserted the crucial distinction between unilateral conduct of a manufacturer and concerted action, the sharpness of which had been allowed to erode. ${ }^{244}$ Second, the law has come increasingly to recognize the importance of competition between manufacturers as the consumer's ultimate protection against undue limitations on competition between distributors. ${ }^{245}$ Finally, courts are increasingly deferential to manufacturers who seek to structure efficient service and distribution systems through which to

appropriateness of preserving the ancient rule against resale price maintenance, but there are also questions concerning the proper analysis of restrictions on nonprice competition.

243. Interestingly, the factual analogy is rather weak, but this very weakness, when compared to the strength of the conceptual analogy, underscores how courts, in responding only to factual appearances, miss the essential truth. A manufacturer, typically the larger party, produces a primary product to which a distributor or retailer, typically a small business, adds certain features-such as advertising and product servicing -in the course of making it attractive to consumers; in the hospital/physician situation, the individual physician, though in some sense a salesman for the hospital, supplies the primary service-a service to which the hospital's services are ancillary. Thus, there is a certain role reversal: the hospital, although seemingly the dominant party economically, resembles more the retailer who provides only space and incidental services enhancing the saleability of the primary product. Although these role differences may seem to take the case out of the manufacturer/distributor paradigm, they appear on deeper analysis to make no difference, see infra text accompanying notes 247-50, thus revealing the oversimplifications of the paradigm on which the law of vertical restraints has long depended. A full appreciation of the hospital/physician situation and a recognition that joint action is required in other situations to combine complementary resources in order to deliver a complex package of goods and services, can help to overcome the current confusion in the law of restricted distribution.

244. In Monsanto Co. v. Spray-Rite Serv. Corp., 104 S. Ct. 1464, 1469 (1984), the Supreme Court sharply reiterated the principle, originally announced in United States v. Colgate \& Co., 250 U.S. 300, 307 (1919), that a selier may refuse to deal for whatever reason as long as it acts independently. See supra note 175; see also Russell Stover Candies, Inc. v. FTC, 718 F.2d 256, 260 (8th Cir. 1983) (rejecting FTC effort to overturn the Colgate doctrine in a resale price maintenance case). For evidence of the earlier attenuation of the Colgate decision, see references cited supra note 238. In Monsanto, the Court held that, to support an inference of conspiracy, there "must be evidence that tends to exclude the possibility that the manufacturer and nonterminated distributors were acting independently," $104 \mathrm{~S}$. Ct. at 1471 , and that evidence must reveal "a conscious commitment to a common scheme designed to achieve an unlawful objective," $i d$. at 1473. This language and the Court's approval of close communications between a manufacturer and its distributors support the earlier analysis of hospital/staff relations and the emphasis there placed on hospital independence.

245. The overriding significance of interbrand as opposed to intrabrand competition was strongly asserted in Continental T.V., Inc. v. GTE Sylvania, Inc., 433 U.S. 36, 51 n.19 (1977). See Easterbrook, supra note 242, at 140-53 (explaining how restricted distribution serves consumer interests). 
compete with other manufacturers. ${ }^{246}$ In light of these trends, a hospital seeking to improve the quality of its product and to compete in an increasingly cost-conscious environment has a better chance that its independent business judgments will be respected.

Although vertically imposed nonprice restrictions resulting from a manufacturer's agreements with its distributors remain subject to close scrutiny under the antitrust rule of reason, ${ }^{247}$ it can be argued that a hospital's independent personnel actions taken in combination with its medical staff should not be subject to comparably close oversight. Essentially, the argument is that advanced earlier ${ }^{248}$-namely, that the hospital/physician relationship should be viewed as a joint venture benefitting consumers. As such, it can be distinguished from the more distant relationship typically prevailing between a manufacturer and the independent wholesalers and retailers who purchase its products for resale. ${ }^{249}$ Although many relationships of this latter kind might also be viewed as procompetitive joint ventures for the marketing of complex packages of goods and services, no such broad justification for vertical restraints has yet been generally adopted. ${ }^{250}$ Nevertheless, because hospital/physician

246. In Monsanto v. Spray-Rite Service Corp., 104 S. Ct. 1464 (1984), the Court stressed the need for the law not to inhibit the use by a manufacturer of "a possible marketing strategy . . . [employing] often costly nonprice restrictions." Id. at 1470.

247. Since Continental T.V., Inc. v. GTE Sylvania, Inc., 433 U.S. 36 (1977), nonprice vertical restraints have been invalidated only rarely. See, e.g., Graphic Prods. Distribs., Inc. v. Itek Corp., 717 F.2d 1560 (11th Cir. 1983); Eiberger v. Sony Corp., 622 F.2d 1068 (2d Cir. 1980). Nevertheless, the issues in such cases include the market power of the manufacturer, efficiency justifications, and the availability of less restrictive alternatives, all issues requiring in-depth factual investigation.

248. See supra text accompanying notes 176-93.

249. Although the joint-venture characterization fits both situations, see supra note 243 , it should be easier for courts to accept it in the hospital setting than in the manufacturer/distributor relationship. First, the hospital and its physicians interact daily on the same premises and necessarily engage in continuous communication and coordination of action; the importance of communication and interaction in the successful distribution of products has only just been recognized in Monsanto Co. v. Spray-Rite Serv. Corp., 104 S. Ct. 1464 (1984), discussed supra note 244. Second, the hospital/physician relationship does not involve discrete sales of tangible goods that in legal contemplation should be free from restraints on alienation in the hands of purchasers; antitrust law has only recently begun to rid itself of this excessively formalistic notion. See Continental T.V., Inc. v. GTE Sylvania, Inc., 433 U.S. 36, 58-59 (1977) (overruling United States v. Arnold, Schwinn \& Co., 388 U.S. 365 (1967)). The same idea was originally invoked to condemn resale price maintenance in Dr. Miles Medical Co. v. John D. Park \& Sons, 220 U.S. 373, 404 (1911), but is under heavy attack today. See, e.g., Easterbrook, supra note 242 . Third, the hospital/physician relationship is demonstrably so close that it should be easy to satisfy a court that real integration, permitting the offering of a "different product," has occurred. See Arizona v. Maricopa County Medical Soc'y, 457 U.S. 332, 355-56 (1982) (if clinic offered complete medical coverage for fiat fee, price-fixing agreement would be proper; distinguishing Broadcast Music, Inc. v. CBS, 441 U.S. 1, 23-24 (1979)). Finally, the fact that the quality of the product is more obviously at stake in the hospital case makes the procompetitiveness of the arrangement easier to recognize. See supra note 218.

250. The Supreme Court appears to be moving in the direction of treating manufacturer/distributor collaboration as procompetitive and thus as subject to no more than relaxed scrutiny. See supra 
relationships have yet to be definitively characterized for antitrust purposes, privileges cases could provide an opportunity for courts to begin explicitly to develop the idea that rule of reason scrutiny should vary in depth according to the procompetitiveness of a joint undertaking and the closeness of and necessity for the challenged collaboration. In time, it seems, courts must find some way to protect collaborators pursuing useful procompetitive purposes from having their motives for every action probed and the benefits of each action judicially balanced against its harms to competition or competitors in some related market. This seems to be an appropriate time and occasion to urge courts expressly to limit their scrutiny of collective actions having positive implications for efficiency and for competition in the larger marketplace.

\section{B. Hospitals' Exclusive Contracts for Physician Services.}

Hospitals must have the capacity to supply certain physician services that are regularly needed to supplement the services provided by attending physicians. Such services as anesthesia, radiology, and pathology are often provided by a physician group with whom the hospital has contracted on an exclusive basis. Although such exclusive contracts have often been challenged under the antitrust laws by physicians who are thereby excluded from access to the hospital's patients, they have generally been upheld in view of the hospital's vertical relationship to the excluded plaintiff and the sound business reasons for the arrangement. ${ }^{251}$

note 249; Easterbrook, supra note 242. Although characterizing a distribution system as a joint venture is one way to clarify the issues in such cases, sound results can be reached in other ways as well. The proper outcome in these cases may be appreciated by focusing on an early but much discussed case upholding what was apparently a horizontal price-fixing agreement among underwriters of a securities issue-in apparent contravention of the per se rule against horizontal price fixing. United States v. Morgan, 118 F. Supp. 621, 828-29 (S.D.N.Y. 1953). Most analysts treat this case, which allowed all the distributors of a new security to agree on the price thereof and even to stabilize the market-thus shifting aftermarket risks to customers, see id. at 683-84-as an anomaly. The decision makes perfect doctrinal sense, however, if the arrangement is understood as involving vertical rather than horizontal restraints. Thus, the issuer of the security can be seen as hiring a lead underwriter to organize a syndicate to assist in marketing his "product" in a way that provides wide coverage of the market and incentives to push the product. Once one conceives of a manufacturer in similar terms-as hiring distribution services in a competitive market and as forming a joint enterprise to market a complex package of goods, information, and accompanying services in competition with the products of other producers-, the parallel with the Morgan case and the logic of reaching the same result become clear. The hospital/physician joint venture, though perhaps easier to recognize, is not fundamentally different in character.

251. See Jefferson Parish Hosp. Dist. No. 2 v. Hyde, 104 S. Ct. 1551, 1561-68 (1984); Dos Santos v. Columbus-Cuneo-Cabrini Medical Center, 684 F.2d 1346, 1352-54 (7th Cir. 1982); Centeno v. Roseville Community Hosp., 107 Cal. App. 3d 62, 70-72, 167 Cal. Rptr. 183, 187-88 (1979); Lewin v. St. Joseph Hosp., 82 Cal. App. 3d 368, 394, 146 Cal. Rptr. 892, 908 (1978); Blank v. Palo AltoStanford Hosp. Center, 234 Cal. App. 2d 377, 385, 44 Cal. Rptr. 572, 577 (1965); Foster, Exclusive 
In examining exclusive hospital/physician contracts, courts have uniformly recognized that such contracts, which are renewable periodically on a competitive basis, give hospitals the opportunity to ensure the availability of services of good quality. Although the hospital/physician agreement has been alleged to create a conspiracy against the plaintiff, it has generally not been viewed with suspicion, but has instead been recognized as the natural result of a hospital decision to deal with one supplier rather than another. The physician group's successful foreclosure of competitors is likewise seen as a normal result of competition and of arm's-length bargaining resulting in an arrangement mutually advantageous to both parties as well as to consumers. In general, the law of exclusive dealing does not much threaten to impede efficient arrangements, providing as it does for judicial intervention only in rare and extreme situations in which a market is tightly and unnecessarily closed to new entrants. ${ }^{252}$

Another legal theory under which exclusive contracts might be attacked was recently considered by the Supreme Court in Jefferson Parish Hospital District No. 2 v. Hyde. ${ }^{253}$ The plaintiff in that case, an anesthesiologist, alleged that the exclusive contract amounted to a tying arrangement, a type of vertical restraint that, in contrast to exclusive dealing contracts, has historically been treated as a per se violation. ${ }^{254}$ Although refusing to overturn its earlier characterization of tying as a per se offense, the Supreme Court majority nevertheless held that the offense had not been established because the hospital lacked sufficient power in the market for hospital services to force patients to accept the services of unwanted anesthesiologists. ${ }^{255}$ In other words, because there were other hospitals to which patients could go, the hospital's insistence that its patients use a particular physician group did not violate the law.

The Court's rationale in Hyde could be read to raise a question about the right of a hospital possessing a unique facility to limit eligibility for admitting privileges. Indeed, if the Court's repeated definition of ty-

Arrangements Between Hospitals and Physicians: Antitrust's Next Frontier in Health ?, 26 ST. Louls U.L.J. 535, 535-39 (1982); FTC, Letter to Robert E. Nord, Esq., (Feb. 24, 1983) (advisory opinion).

252. See generally Tampa Elec. Co. v. Nashville Coal Co., 365 U.S. 320, 325-35 (1961) (twentyyear requirements contract affecting less than $1 \%$ of relevant market upheld); FTC v. Motion Picture Adv. Serv. Co., 344 U.S. 392, $395-98$ (1953) (exclusive dealing contracts, with $40 \%$ of available outlets, limited to one-year duration); United States v. Standard Oil Co., 337 U.S. 293, 299-320 (1949) (exclusive dealing contracts of six-month duration foreclosing $6.7 \%$ of relevant market found illegal). The later decisions appear to undercut the rigid rule of the Standard Oil case. See Twin City Sportservice Inc. v. Charles O. Finley \& Co., 676 F.2d 1291, 1301-09 (9th Cir.), cert. denied, 459 U.S. 1009 (1982); Beltone Elecs., 100 F.T.C. 68, 204 (1982).

253. 104 S. Ct. 1551 (1984).

254. Id. at 1556-58.

255. Id. at 1556-57. 
ing in such terms as "the use of market power to force patients to buy services they would not otherwise purchase" 256 were accepted at face value, any excluded practitioner could argue that the hospital had subjected patients who might prefer him over other doctors to a coercive tying arrangement. This absurd result can be avoided by noting the fact, buried deep in the footnotes in Hyde, ${ }^{257}$ that the hospital in that case had a right to share in the profits of the preferred anesthesiology group and could therefore itself be seen as a competitor of Dr. Hyde. Although Justice Stevens's opinion is remarkable for the way it obscures the importance of this fact, the tying offense has always involved a seller's use of power over one product to expand the market for some other product which he himself sells. ${ }^{258}$ Despite Justice Stevens's almost exclusive emphasis on the coercive element and his concern about forcing consumers to do something they would prefer not to do, the tying principle would appear to be inapplicable to the typical privileges case, which does not involve a physician seeking to compete with the hospital itself. Fortunately, the Court did acknowledge that, in the Hyde situation, "the range of alternatives open to the patient would be severely limited [in any event] by . . . the hospital's unquestioned right to exercise some control over the identity and the number of doctors to whom it accords staff privileges."259

Although the Hyde decision should not affect a hospital's right to select physicians, it creates other severe problems for hospitals that do occupy powerful market positions, owing perhaps to the natural monopoly characteristics of their markets. Can such a hospital, for example, integrate vertically by employing its own anesthesiologists and excluding nonemployees? Can it require that patients accept the products or services of its own-or a contracting-food service, pharmacy, or clinical laboratory? Must the hospital avoid providing all tied goods and services itself and also eschew any contract or lease giving it a share in the earnings of those who enjoy its franchise? The Hyde opinion implies that these issues should be resolved in such a way that no hospital can exercise the power inherent in its middleman position in the market to foreclose some option that some consumer might wish to have available. ${ }^{260}$ This idea, which fortunately is not well established in antitrust law,

256. Id. at 1566.

257. Id. at $1555 \mathrm{n} .4$.

258. The legal principle's limitation to the forcing of one's own product appears clearly only in one footnote. Id. at 1559 n.20 (quoting P. AREeDA \& D. TURNER, ANTITRUst LAW $\$ 1134 \mathrm{a}$ at 202 (1980)).

259. $104 \mathrm{~S}$. Ct. at 1568.

260. See id. at 1565-66 (unlawful tying occurs wherever market power is used to "force" consumers to buy the tied product). 
seems to miss entirely the great benefit that most ignorant consumers might derive from having a sophisticated middleman with bargaining power make choices on their behalf. The argument that hospitals can perform useful services to consumers in this regard, an argument heavily insisted upon in this article, seems to have escaped Justice Stevens on this occasion. ${ }^{261}$ The Court would have done better if - as the Federal Trade Commission, the Antitrust Division of the Justice Department, and the four concurring justices wanted-it had retracted the per se rule for tying arrangements and substituted instead the analytical tools employed in exclusive dealing cases. ${ }^{262}$

\section{Health Care Practitioners Versus Other Middlemen.}

Health care practitioners have repeatedly invoked the antitrust laws to challenge various market intermediaries for adopting business practices that have the effect of disadvantaging them competitively. The most common targets of such complaints have been health insurers that either refuse to cover the services of such practitioners at all or provide coverage on terms that are in some way disadvantageous to them. ${ }^{263}$ Like cases involving hospital staff privileges and exclusive contracts, these cases involve a claim that some middleman is preventing competition by interfering with a licensed professional's freedom to compete for patients. Some courts have recognized clearly that these middlemen may properly be viewed as legitimate decisionmakers accountable to consumers and thus as a vital part of the working market, not an impediment to its operation. ${ }^{264}$ Other courts, however, have been confused by plaintiffs' claims

261. Justice Stevens has recognized elsewhere how selectivity practiced by health insurers can serve consumer interests. Arizona v. Maricopa County Medical Soc'y, 457 U.S. 332, 353 (1982) (citing Group Life \& Health Ins. Co. v. Royal Drug Co., 440 U.S. 205 (1979)).

262. See supra note 252 and accompanying text. Amicus curiae briefs filed in Hyde by the FTC and the Solicitor General took positions similar to those taken in the concurring opinion of Justice O'Connor. See 104 S. Ct. at 1569-76 (Burger, C.J., Powell, and Rehnquist, JJ. joined the O'Connor concurrence); Brief for the United States as Amicus Curiae in Support of Reversal at 20-22, 27-28 (joint brief by the Department of Justice, the Solicitor General, and the FTC).

263. See cases cited infra notes 264 and 265, several of which involved hospitals rather than individual practitioners. For a case involving a different kind of insurance, see Nurse Midwifery Assocs. v. Hibbett, 549 F. Supp. 1185 (M.D. Tenn. 1982) (physician supervising nurse midwives denied malpractice liability coverage by insurer under control of competing physicians).

264. A series of cases in which pharmacists failed to obtain relief against insurers followed the decision in Group Life \& Health Ins. Co. v. Royal Drug Co., 440 U.S. 205 (1979). E.g., Royal Drug Co. v. Group Health \& Life Ins. Co., 737 F.2d 1433 (5th Cir. 1984); Medical Arts Pharmacy, Inc. v. Blue Cross \& Blue Shield, Inc., 675 F.2d 502 (2d Cir. 1982); Feldman v. Health Care Serv. Corp., 562 F. Supp. 941 (N.D. Ill. 1982); Sausalito Pharmacy, Inc. v. Blue Shield, 544 F. Supp. 230 (N.D. Cal. 1981), aff'd, 677 F.2d 47 (9th Cir.), cert. denied, 459 U.S. 1016 (1982). See generally Comment, Prepaid Prescription Drug Plans under Antitrust Scrutiny: A Stern Challenge to Health Care Cost Containment, 75 Nw. U.L. REV. 506, 536-37 (1980). Cases rejecting claiıns by health care providers of other types include Kartell v. Blue Shield, 47 ANTITRUST \& TRADE REG. REP. (BNA) 1051 (1st 
that the antitrust laws entitle them to fair treatment. ${ }^{265}$ The lessons learned above in examining hospital privileges can be useful in resolving disputes involving substantial intermediate decisionmakers of other kinds.

The antitrust cases involving complaints against insurance plans generally distinguish among insurers-as they should-on the basis of whether or not they occupy a purely vertical market relationship to the plaintiff. Thus, insurers that are not controlled by competitors of disadvantaged practitioners have generally been permitted to act in accordance with their business judgments. ${ }^{266}$ Although this result has sometimes been reached by invoking the antitrust exemption for the "business of insurance" in the McCarran-Ferguson Act, ${ }^{267}$ it should be

Cir. Nov. 28, 1984) (physicians); Pennsylvania Dental Ass'n v. Medical Serv. Ass'n, 745 F.2d 248 (3d Cir. 1984) (state and local dental associations); Desgranges Psychiatric Center v. Blue Cross \& Blue Shield, 124 Mich. App. 237, 333 N.W.2d 562 (1983) (provider of outpatient mental health care services); Michigan Ass'n of Psychotherapy Clinics v. Blue Cross \& Blue Shield, 118 Mich. App. 505,325 N.W.2d 471 (1982) (outpatient psychiatric clinics). For strong holdings rejecting the analogous claims of auto body repair shops against auto insurers, see Quality Auto Body, Inc. v. Allstate Ins. Co., 660 F.2d 1195 (7th Cir. 1981); Chick's Auto Body v. State Farm Mut. Auto. Ins. Co., 168 N.J. Super. 68, 88, 401 A.2d 722, 732 (1979) ("plaintiffs seek to use the antitrust laws as a shield from . . . [pricel competition"), aff'd per curiam, 176 N.J. Super. 320, 423 A.2d 311 (1980). See generally Kallstrom, Health Care Cost Control by Third Party Payors: Fee Schedules and the Sherman Act, 1978 DuKE L.J. 645 (arguing that insurer-imposed fee schedules can be effective in combating price escalation in the third party payment system and that the Sherman Act does not proscribe the use of such fee schedules); Rankin \& Wilson, Sausalito Pharmacy and the Antitrust Consequences of Insurer-Imposed Limitations on Fees, 26 ST. Louls U.L.J. 601 (1982) (addressing the antitrust consequences of maximum limitations imposed by insurers on providers' reimbursement through provider agreements and similar arrangements; concluding that carefully drawn programs should survive in-depth antitrust scrutiny).

265. The lower courts that were later reversed in Kartell v. Blue Shield, 47 ANTITRUST \& Trade Reg. ReP. (BNA) 1051 (1st Cir. Nov. 28, 1984), and in Michigan Ass'n of Psychotherapy Clinics v. Blue Cross \& Blue Shield, 118 Mich. App. 505, 325 N.W.2d 471 (1982), were prepared to find a section 1 violation based on an insurer's penalization of providers that would not accept as payment in full whatever it was willing to pay. See Kartell v. Blue Shield, 582 F. Supp. 734, 755 (D. Mass. 1984); Michigan Ass'n of Psychotherapy Clinics v. Blue Cross \& Blue Shield, 118 Mich. App. at 512, 325 N.W.2d at 474-75 (reciting trial court findings). In the absence of unlawful monopolization (or "monopsonization"), however, antitrust law provides little justification for regulating the pricing or other practices of firms acting unilaterally. See supra note 175.

266. See cases cited supra note 264.

267. 15 U.S.C. $\S 1011$ (1983). Cases relying on the McCarran Act to terminate challenges to insurer refusals to deal and coverage practices include Klamath-Lake Pharmaceutical Ass'n v. Klamath Medical Serv. Bureau, 701 F.2d 1276, 1284-90 (9th Cir.) (tying of prescription drugs to other health services held exempt from antitrust challenge), cert. denied, 104 S. Ct. 88 (1983); Frankford Hosp. v. Blue Cross, 554 F.2d 1253, 1253-54 (3d Cir. 1977) (defendant hospitals exempt from Sherman Act absent showing of boycott, coercion, or intimidation), cert. denied, 434 U.S. 860 (1977). The McCarran defense to such actions was substantially narrowed in Union Labor Life Ins. Co. $v$. Pireno, 458 U.S. 119, 133-34 (1982) (insurer and provider organization review of claims for insurer held not exempt), and Group Life \& Health Ins. v. Royal Drug Co., 440 U.S. 205, 208-10, 232-33 (1979) (insurer bargaining for lower prices held not exempt; Frankford Hospital decision disapproved). 
equally easy to reach the same result under the Sherman Act. Indeed, the McCarran exemption would not seem applicable at all against claims of harm to competition in a market for insured services-as opposed to harms occurring in markets in which insurers themselves compete. ${ }^{268}$ Courts that have struggled with McCarran issues might more appropriately have proceeded to grant summary judgment on the Sherman Act claim. Even if an independent insurer is alleged to have conspired with the providers benefitting from its policies, a court should usually be able to dismiss the case quickly on the basis of an apparent business justification. ${ }^{269}$

In those cases that have involved an insurer under the control of providers competing with the disadvantaged plaintiff, courts have been quick to intervene. 270 They have, however, neglected to adopt the two-

268. In Union Labor Life Ins. v. Pireno, 458 U.S. 119 (1982), the Supreme Court set as one criterion for applying the exemption "whether the practice is limited to entities within the insurance industry." Id. at 129 . Because the exemption was intended primarily to protect intra-industry cooperation under circumstances where state regulation protected consumers against monopolistic practices, it would be improper to let it also shelter monopolistic practices in markets for insured services, which state insurance regulators have little capacity or mandate to police. Recent cases rejecting McCarran defenses where the alleged anticompetitive effects occurred in markets for provider services include Ratino v. Medical Servs., 718 F.2d 1260, 1265-67 (4th Cir. 1983); Hahn v. Oregon Physicians Serv., 689 F.2d 840, 843-44 (9th Cir. 1982),cert. denied, 103 S. Ct. 3115 (1983); Virginia Academy of Clinical Psychologists v. Blue Shield, 624 F.2d 476, 483-84 (4th Cir. 1980), cert. denied, 450 U.S. 916 (1981); Trident Neuro-Imaging Lab. v. Blue Cross \& Blue Shield, 568 F. Supp. 1474, 1480-83 (D.S.C. 1983); Nurse Midwifery Assocs. v. Hibbett, 549 F. Supp. 1185, 1192-93 (M.D. Tenn. 1982); Kartell v. Blue Shield, 542 F. Supp. 782, 792-94 (D. Mass. 1982), rev'd on other grounds, 47 ANTITRUST \& TRADE REG. REP. (BNA) 1051 (1st Cir. Nov. 28, 1984).

269. In Virignia Academy of Clinical Psychologists v. Blue Shield, 624 F.2d 476, 483 (4th Cir. 1980), cert. denied, 450 U.S. 916 (1981), criticized on other grounds, infra text accompanying notes 272-73, the court readily rejected, despite evidence of consultation, an allegation that an insurer conspired with an association of psychiatrists in developing its coverage of psychologists' services. In Glen Eden Hosp. v. Blue Cross \& Blue Shield, 740 F.2d 423, 428 (6th Cir. 1984), the court permitted discovery to determine whether Blue Cross had acted in concert with participating hospitals and the state hospital association in establishing its payment policies. On the significance of direct provider control, see infra note 270 . In addition to showing its freedom from such control, a Blue Cross or Blue Shield plan must be able to show that it dealt with providers individually, not collectively, there being no procompetitive justification for collective action by providers here comparable to that supporting a hospital's encouragement of its medical staff to organize. See infra text accompanying notes 62-82. It is possible that some Blue Cross or Blue Shield plans, even independent ones, have adopted a policy of enforcing, in return for discounts and other favors, the policies of a provider cartel.

270. See, e.g., Ratino v. Medical Servs., 718 F.2d 1260, 1265-67 (4th Cir. 1983); St. Bernard Hosp. v. Hospital Serv. Ass'n, 712 F.2d 978, 985-89 (5th Cir. 1983), cert. denied, 104 S. Ct. 2342 (1984); Addino v. Genesee Valley Medical Care, Inc., 593 F. Supp. 892, 895-901 (W.D.N.Y. 1984); Trident Neuro-Imaging Lab. v. Blue Cross \& Blue Shield, 568 F. Supp. 1474, 1478-79 (D.S.C. 1983); cf. Nurse Midwifery Assocs. v. Hibbett, 549 F. Supp. 1185, 1187 (M.D. Tenn. 1982) (denial of insurance by physician-owned insurer for purpose of restraining competition in maternity services market; held not exempt from Sherman Act); see also FTC, MEdical PARTICIPATION IN CONTROL of Blue Shield and Certain Other Open-Panel Medical Prepayment Plans 158-73 
step analysis suggested in earlier discussion. ${ }^{271}$ Under that approach, the procompetitive justification for allowing a powerful combination of practitioners to organize an insurance plan at all would have to be established first before proceeding to examine the lawful joint venture's specific business practices under a standard properly respectful of the venture's legitimacy and procompetitiveness. In Virginia Academy of Clinical Psychologists v. Blue Shield, ${ }^{272}$ the court of appeals, appearing to adopt a regulatory posture vis-a-vis a Blue Shield plan under the control of a state medical society, penalized discriminatory coverage of the plaintiffs' services even though the insurer's practice had a convincing business justification. ${ }^{273}$ The court's failure to consider the legality of the plan's sponsorship by organized medicine as a distinct issue reflected the strategic decision of the private plaintiffs to seek only relief from the discriminatory coverage provision and not to challenge the sponsorship of the insurer as such; had they pursued the latter theory, of course, they could not have been sure that the insurer, once independent, would have adopted a policy any more to their liking. The court's ready acceptance of a role requiring close regulation of the insurer's decisions, although a consequence of the plaintiff's choice of a legal theory, seems to have been a mistake. Not having been asked to condemn the control relationship itself, the court should have assumed the legality of the physician joint venture and examined its policies under a rule of limited scrutiny-unless, of course, the essential-facilities doctrine applied and dictated closer scrutiny as a way of preserving the benefits of the joint venture while minimizing its potential for anticompetitive harm.

Cases challenging the business policies of a health insurer under the control of a powerful provider organization will not ordinarily be candidates for treatment under the essential-facilities doctrine. A single insurer is unlikely to be a truly vital resource, because it would rarely possess a life-and-death power over the ability of a plaintiff to compete in the market at all. Moreover, practitioners disadvantaged by an insurance plan, in addition to competing for patients who have nondiscriminatory coverage-or no coverage-for the particular type of service, can always seek to persuade purchasers of objectionable insurance to change their

(1979). See generally FTC, Physician Agreements to Control Medical Prepayment Plans, 46 Fed. Reg. 48,982, 48,983-84 (1981).

271. See supra text accompanying notes 115 \& 193-94.

272. 624 F.2d 476 (4th Cir. 1980), cert. denied, 450 U.S. 916 (1981).

273. Id. at 485-86. The court's legal theory is in fact quite unclear, and the decision may be interpreted narrowly and less controversially as a simple condemnation of a horizontal agreement between two insurers to adopt the challenged form of coverage. Such a reading, though strained, would obviate the criticism advanced in the text, which tracks the fuller analysis in Havighurst \& King, supra note 57 , at 329-30. 
coverage. There is no good reason why existing insurance coverage should not be presumed for antitrust purposes to reflect consumer demand for various providers' services and thus to obviate the necessity for all but minimal scrutiny of the business practices of lawful plans under competitor control. Even though there are arguable defects in such markets, ${ }^{274}$ those problems could be, and have been, dealt with through regulation; ${ }^{275}$ antitrust courts should not allow themselves to be lured into assuming a regulatory role. The court in Virginia Academy appears to have erred not only in failing to recognize the overriding structural issue but also in reviewing the insurer's coverage provisions under a standard appropriate only for an essential-facilities case.

Competitor-sponsored organizations that engage in institutional accreditation or personnel credentialing represent another type of market intermediary whose actions can disadvantage competitors of its sponsors. Disappointed applicants for accreditation or certification, although not excluded from the market, are likely to be significantly disadvantaged and may hope for assistance from an antitrust court. I have argued at length in a recent article ${ }^{276}$ that a limited-scrutiny, rational-basis test should be applied to the actions of competitor-controlled credentialing and accrediting programs in view of the procompetitive value of the information that such programs provide to consumers and other users. Although that recommendation might seem inconsistent with the earlier recommendation ${ }^{277}$ that close scrutiny is appropriate for some competitor-controlled hospital privileges decisions, it is not. In both instances-

274. Most health insurance is purchased by employers on a group basis and not individually, and it is therefore possible that employees who would like-and be willing to pay for-coverage entitling them to patronize a particular class of providers might not have their preference for such insurance recognized if they constituted only a minority of the covered group. See, e.g., Michigan Ass'n of Psychotherapy Clinics v. Blue Cross \& Blue Shield, 118 Mich. App. 505, 325 N.W.2d 471 (1982) (insurance coverage used by a labor union was changed so as no longer to cover the service of certain mental health professionals who had been in demand by some beneficiaries). The market failure traceable to majoritarian rule in employment groups can be addressed in part by offering employees "multiple choice" health plans, an increasingly popular idea. See C. HAvigHuRST, supra note 1, at 396-416. A policy move that would somewhat alleviate the disadvantage of nonphysicians would be a new limitation on the federal tax subsidy for employer-purchased health insurance; without a tax incentive for covering as many health services as possible, employers would cut back coverage of routine health services of the kind that nonphysicians frequently provide. Such a change in tax treatment of private health insurance makes sense for other policy reasons as well. See id. at 387-96.

275. Many states have passed laws requiring an insurer, if it covers a service when provided by a physician, also to cover it when it is lawfully provided by some other specified type of licensed professional. See, e.g., Blue Cross v. Commonwealth, 221 Va. 349, 366, 269 S.E.2d 827, 838 (1980) (a challenge to the constitutionality of a Virginia statute of this kind). It is not clear that such regulation, forcing groups to buy more coverage than they want, is wise as a policy matter. See supra note 274.

276. Havighurst \& King, supra note 57, at 158-201.

277. See supra text accompanying notes 159-73. 
as well as in the case of competitor-sponsored insurance coverage-the key to eligibility for limited scrutiny is the presence of some intervening independent decisionmaker not in a horizontal relationship with the disadvantaged individual. Thus, a hospital acting independently on a privileges matter fills a role closely analogous to that of the myriad of independent purchasers and other decisionmakers who must decide for themselves what the presence or absence of private accreditation or certification means. In each case, because there is a market at work, the court's job is simply to police easily identifiable abuses while not interfering with presumptively valid business judgments. Only when competitors collaborating in a useful joint venture are in a position, by themselves, to exclude competitors from the market is the risk of anticompetitive abuse great enough possibly to justify an antitrust court, proceeding under the essential-facilities doctrine, in taking a close regulatory look at each collective action.

The legal rules applicable to competitor collaboration in health care, as in all other industries, must be designed so as not to frustrate useful joint activities. The first task of antitrust courts is to consider whether a particular collaboration is compatible with the continued operation of the competitive process as a guarantor of consumer welfare; 278 second, the courts can properly impose reasonable requirements on legitimate, but powerful, joint ventures if a less restrictive alternative exists that can materially improve the likelihood of net procompetitive effects; ${ }^{279}$ and, third, they can properly supply limited oversight of day-to-day business actions of procompetitive joint ventures to ensure that no obvious abuses occur. ${ }^{280}$ To go farther, however, is probably to do more harm than good-if not in the particular case, then certainly in the larger market by impairing incentives for efficient behavior.

Unfortunately, all antitrust cases involving challenges to collaborators who act in ways that are harmful to their competitors present a danger that has long been a fundamental problem in antitrust law. Courts that have been asked to ensure that a particular plaintiff-competitor was fairly treated have frequently forgotten that the policy of promoting competition specifically contemplates that firms will strive to advance their own interests at the expense of others and have jumped to the conclusion that protecting and preserving competitors is the same thing as protecting competition. Such judicial interventions in the name of fairness necessarily inhibit the selectivity and freedom of action that are vital to the achievement of efficiency through decentralized decisionmaking in free

278. See supra text accompanying notes $62-82$ \& 176-93.

279. See supra text accompanying notes 121-173.

280. See supra text accompanying notes 174-215. 
markets. The rules suggested in this article strike the right balance between the concerns of fairness and efficiency, first, by stressing the importance of ascertaining that decisions are made by a party that canbecause of the competitive environment-be presumed to act for the benefit of consumers and, second, by protecting that decisionmaker and its essential collaborators from litigation risks that could only diminish their efforts to serve consumers well. The goal of the analysis here has been to persuade antitrust courts to resist their regulatory, interventionist impulses and to view their primary task as the allocation of decisionmaking authority-both within the private sector and between the private sector and the courts themselves-so as to maintain a robust competitive process as society's main vehicle for promoting economic efficiency and enhancing consumer welfare.

\section{Conclusion: A Strengthened Role for Hospitals}

This article has argued that antitrust courts, and public policy generally, should not unduly obstruct or regulate a hospital's selection of physicians and other practitioners who may use its facility to treat patients. To ensure that hospitals have reasonable freedom of action, a court, once it is satisfied that the hospital and not the medical staff has made a particular staffing or privileges decision, should refrain from closely scrutinizing the action taken. Accordingly, a court should dismiss any antitrust or common-law challenge to the hospital's action unless no rational basis for that action appears. Strict scrutiny of a personnel decision ${ }^{281}$ is appropriate only where a breach of an explicit or implied contract is alleged, where staff physicians are charged with the common-law tort of unfair competition, or where a substantial danger to competition raising antitrust concerns is present. A danger of the latter

281. This article's use of the notions of "strict" or "close" versus "limited" scrutiny needs some explanation because antitrust courts have not customarily used this terminology, which is more familiar in constitutional law. The same may be said of the suggestion that a hospital's action should be upheld if it has a "rational basis." The object here is not to start an argument conceruing the utility of these particular characterizations of the judicial function but is instead to suggest that courts can improve the quality of antitrust rules by going beyond the customary dichotomization between per se prohibitions and a supposedly unitary rule of reason that calls for the same level of scrutiny in every case. Recently the Solicitor General has suggested that, in certain rule of reason cases, a "quick look" may be all that is required. Brief for the United States as Amicus Curiae in Support of Affirmance at 7-8, NCAA v. University of Oklahoma, 104 S. Ct. 2948 (1984); Brief for the United States as Amicus Curiae at 19-20, Arizona v. Maricopa County Medical Soc'y, 457 U.S. 332 (1982). Others have advanced the notion of a "truncated" rule of reason. See, e.g., Sullivan \& Wiley, Recent Antitrust Developments: Defining the Scope of Exemptions, Expanding Coverage, and Reforming the Rule of Reason, 27 UCLA L. REV. 265, 330-36, 341-42 (1979). For another analysis using similar terminology to describe judicial treatment of another kind of procompetitive collaboration, see Havighurst \& King, supra note 57, at 158-84. 
variety exists only where the specific conditions inviting application of antitrust law's "essential-facilities" doctrine are satisfied-that is, where competitors of an applicant control his access to hospital privileges and where the applicant must have such privileges in order to compete effectively. Adherence to the legal principles developed herein should permit courts to dispose of many antitrust and common-law challenges to hospitals' privileges decisions without full discovery or a full trial.

The hospital's independent participation in privileges decisions, not the noninvolvement of the medical staff, should be the key to relaxed antitrust scrutiny. Physician participation in these decisions does not signify a conspiracy between the hospital and its doctors and should not be viewed as a suspicious circumstance. Instead, physician involvement is fully in keeping with the legitimate purpose of operating the hospital. Accordingly, the hospital/physician collaboration should be viewed for antitrust purposes as a productive joint venture entitled to have its procompetitive, efficiency-enhancing features viewed favorably under the rule of reason. Although antitrust case law is not seriously inconsistent with these observations, courts must distinguish more sharply between cases in which a hospital, standing in a vertical relationship to the plaintiff, asserts its own competitive interests and cases in which a medical staff-comprising competitors of the plaintiff and thus afflicted with an inevitable conflict of interests-exercises essentially final authority over who can use the facility. Once these distinctions are drawn, the more extreme conceptions of what it means to be a "self-governing" medical staff will begin to disappear. ${ }^{282}$ Hospitals, in order to minimize their antitrust risks, will require their medical staffs to accept a demonstrably subordinate role in the administration of privileges. Likewise, staff physicians will have to be counselled that they can ensure their own safety from antitrust challenges only by accepting a position that is, in substance as well as form, only advisory to hospital management.

Reserving close scrutiny for cases that present a real threat of anticompetitive abuse by physicians would leave properly managed hospitals relatively free of inhibitory antitrust risks in carrying out their new responsibilities for maintaining the quality and controlling the cost of medical care. The analysis herein treats this development as generally beneficial, on the assumption that hospitals dispensing admitting privileges will generally act in accordance with consumer interests to the extent that the external environment permits. This assumption is somewhat at odds, however, with conventional wisdom in the health care

282. Cf. Johnson, Hospital Boards Should Abandon Medical Staff 'Self-Governance', MoD. HEALTHCARE, July 1983, at 134, 140. 
field, which holds that corporations, particularly those operated for profit, are untrustworthy decisionmakers. A corollary of this view is that consumers are better off if decisionmaking is in the hands of professionals who subscribe to an ethical code that inhibits exploitation of patients' ignorance and vulnerability. A reflection of this perception is found in the natural assumption by many physicians and other practitioners that their exclusion from a hospital ipso facto limits competition. The premise underlying this assumption is that competition works best when patients have the widest possible choice among practitioners and that competition among hospitals, which are necessarily few in any market, provides inadequate assurance that consumers will be well served. Many find it liard to think of a hospital decision excluding a particular practitioner as a manifestation rather than a negation of healthy competition. The natural impulse of those who distrust the liospital as an agent of consumer interests is to subject the hospital to an affirmative, public-utility-type duty to keep its facilities open to all reasonably qualified practitioners. Although the case for relying more on competitive decisionmaking by hospitals and less on competition among health care practitioners cannot be fully examined in concluding this article, a few observations are possible.

The overriding problem with relying on competition in healtli care markets is that consumers are uninformed about their options and too unsophisticated to choose wisely even when information is available. Given these circumstances, hospital competition has something to contribute. For one thing, it is arguable that the visibility of hospitals makes competition among a limited number of them more effective than competition among a mucls larger number of individual practitioners would be. In a market offering numerous choices but poor information about each of them, competitors may actually enjoy more market power individually than would any of a few competitors in another market where reputations were readily ascertainable. Economists Mark Pauly and Mark Satterthwaite have observed this economic anomaly, illustrating it by suggesting that, in a community with only three physicians, nearly everyone would have an idea about the characteristics of each, whereas, in a community with many doctors, comparative evaluations would not be readily available. ${ }^{283}$ Thus, a degree of concentration may actually enhance competition in information-poor markets, especially if, as appears to be the case with hospitals, oligopolistic coordination of pricing and output is difficult because services are differentiated.

283. See Pauly \& Satterthwaite, The Pricing of Primary Care Physicians' Services: A Test of the Role of Consumer Information, 12 BELL J. ECON. 488, 490 (1981). 
Consumer information problems can also be ameliorated by hospital competition in selecting physicians. By lending their reputations to the physicians chosen, hospitals perform a certification function that gives consumers useful information about physicians' technical skills. Also, because hospitals have the sophistication that consumers lack in selecting physicians, they are a direct answer to the problem of consumer ignorance. To the extent that hospitals are treated as public utilities with duties to practitioners, their reliability as sources of useful information and as allies of the consumer may diminish.

Many hospitals enjoy monopoly positions in their respective markets both because of economies of scale that create natural-monopoly conditions in small markets and because of certificate-of-need laws that inhibit market entry. This market dominance can create some apparent disparities of bargaining power that physicians may see as exposing them to exploitation. Nevertheless, the market for physician services to hospitals is not localized. Hospitals possessing local market power cannot force physicians to accept heavy burdens without driving some of them away or at least stopping the influx of new physicians essential to the hospital's success. In addition, hospitals that are the sole facility in their marketing areas still face significant competition that keeps them responsive to both physician and patient concerns. Thus, hospitals in adjoining areas and referral hospitals at a greater distance are realistically available to many patients, and their competition for the marginal patient creates incentives for good performance that benefits all patients. In addition, numerous opportunities exist for substituting ambulatory services for hospital inpatient care, again creating significant competitive pressures on a monopoly institution. Local physicians, because they are able to influence patients' choices among available options, are valued customers of the hospital and cannot be victimized to a degree that should be regarded as worrisome.

Even though many physicians purport to believe that hospitals cannot be trusted to represent consumer interests, their true concern is probably that hospitals represent certain patient interests altogether too well; in particular, hospitals are inconvenient adversaries because they transmit cost concerns originating on the demand side of the market to physicians on the supply side. On the other hand, physicians need not fear that the changes occurring within hospitals will deprive them of all influence over hospital decisions. Hospitals will always need physicians, particularly skilled and conscientious ones who are willing to assist in quality-assurance and cost-containment efforts. As a result, they will strive to create conditions that are congenial to physicians, will respect their judgments, and will accommodate their interests wherever possible. 
In short, it would appear that the intra-institutional power shifts that are occurring are simply correcting existing imbalances and will stop well short of forcing physicians into positions inconsistent with their professional and independent status.

The fundamental reality behind the changes that are occurring in hospital/physician relationships today, and that would be further facilitated by adoption of the legal principles advocated in this article, is that consumers are finally obtaining adequate representation of all their various interests. Physicians have always claimed to represent those interests and have sought to do so exclusively. At many points, however, physicians failed to give sufficient weight to significant consumer concerns, especially those involving cost. Other consumer agents are therefore appearing on the scene or are assuming broader responsibilities than they were previously allowed to exercise. The hospital, standing at a central point in the most complex and costly health care transactions, is a vital link in the effort to make the health care industry efficient in both productive and allocative terms. ${ }^{284}$ Although a vital and particularly effective ally of the consumer, the hospital is not his only advocate in these transactions. Indeed, the physician remains the patient's best friend and most trusted agent in his effort to obtain the services he needs. Although tensions are increasing between payers, hospitals, and physicians, these tensions are healthy insofar as they reflect the difficult trade-offs that bedevil health care decisionmaking and that must somehow be resolved if efficiency is to be realized. Each of the players in these intense dramas can be seen to represent the consumer and at least one facet of his various

284. A growing body of research indicates that hospitals under the control of active governing boards, with highly structured medical staffs, provide better quality care than is found in hospitals with loosely structured medical staffs in which hospital-wide decisionmaking is dominated by the medical staff. See Morlock \& Nathanson, Power and Influence, in Health Care Management 250, 271-76 (S. Shortell \& A. Kaluzny eds. 1983); Shortell, Hospital Medical Staff Organization: Structure, Process and Outcome, HoSP. AD., Spring 1974, at 96, reprinted in HosPITAL ORGaNIZATION AND MANAGEMENT 198-207 (J. Rakich \& K. Darr eds., 3d ed. 1983) (reviewing three major

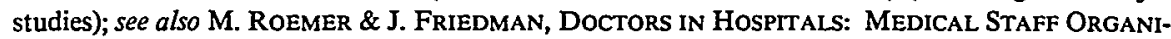
zATION AND HoSPITAL PERformance 285 (1971) (one of the most influential empirical studies, concluding that a "highly structured" medical staff organization with relatively more doctors on full-time contract with the hospital is "optimal"); Flood \& Scott, Professional Power and Professional Effectiveness: The Power of the Surgical Staff and the Quality of Surgical Care in Hospitals, 19 J. HEALTH \& SoC. BEHAV. 240 (1978) (finding that the quality of care was not related to the power of the surgical staff but was strongly associated with the power of the hospital administration). There is also evidence that hospitals with highly-structured medical staffs have significant physician participation in decisionmaking, resulting in improved care. See Shortell \& LoGerfo, Hospital Medical Staff Organization and Quality of Care: Results for Myocardial Infarction and Appendectomy, 19 MED. CARE 1041, 1051-52 (1981) (concluding that medical staff organizational factors such as involvement of the medical staff's president with the hospital governing board, overall physician participation in decisionmaking, frequency of medical staff committee meetings, and percentage of active staff physicians on contract are positively associated with quality). 
vital concerns. ${ }^{285}$ Judicial intervention in the adversarial relationship between hospitals and physicians should be tailored to facilitate, not to inhibit, voluntary action, decentralized decisionmaking, arm's length bargaining, and selectivity - the crucial features of a health care marketplace in which society struggles to get good value for its health care dollar.

285. These observations have implications for current Medicare proposals to integrate the pay- ment of hospitals and physicians for inpatient services into a single lump sum based on the patient's diagnosis. See, e.g., Senate Special Comm. on Aging, Medicare: Paying the PhysicianHistory, Issues, AND OPTIONS 28-29 (Comm. Print 1984). Although government might achieve effective cost control by such a measure, one should be concerned that such an approach would force an unnatural degree of integration and unduly impair the physician's role as an advocate for patients' interests. Indeed, Medicare's prospective payment system is itself open to criticism for forcing hospitals and, indirectly, physicians into the service of objectives other than those of consumers. In the long run, a voucher approach to financing health care for the elderly would seem to be the best way to preserve essential values without inviting unwarranted cost increases. See supra note 14. 